\title{
PSYCHOLOGICAL BASIS OF PROFESSIONAL PROBLEM-SOLVING
}

Collective monograph

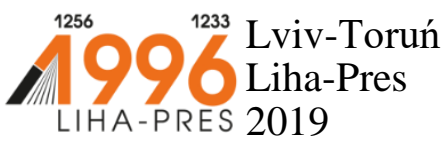




\section{Reviewers:}

Konrad Janowski, PhD, Vice-dean of the Faculty of Psychology, University of Economics and Human Sciences in Warsaw (Republic of Poland); Prof. dr hab. Tadeusz Dmochowski, University of Gdansk (Republic of Poland).

Psychological basis of professional problem-solving : collective monograph / M. Smulson, M. Tomchuk, A. Chornyi, V. Demskyi, A. Makovskyi, A. Yakymchuk, T. Scherban, O. Volobuieva. Lviv-Toruń : Liha-Pres, 2019. - 178 p.

ISBN 978-966-397-152-0

Liha-Pres is an international publishing house which belongs to the category „C" according to the classification of Research School for Socio-Economic and Natural Sciences of the Environment (SENSE) [isn: 3943, 1705, 1704, 1703, 1702, 1701; prefixMetCode: 978966397]. Official website www.sense.nl. 


\section{CONTENTS}

THE SIGNIFICANCE OF PROBLEM-SOLVING

IN THE PROFESSIONAL ACTIVITY

Maryna Smulson

1

PROFESSIONALISM OF ENGINEERS-BORDER GUARDS

AS A FACTOR TO ACCOMPLISH THEIR

SERVICE DUTIES

Mykhailo Tomchuk

PSYCHOLOGICAL PRINCIPLES OF SOLVING

PROFESSIONALLY AIMED SITUATIONS

IN THE PROCESS OF PROBLEM-BASED LEARNING

Artem Chornyi

40

FORMATION OF PROFESSIONAL SELF-ASSESSMENT

OF BORDER GUARD OFFICERS-INTENDING MANAGERS

Valentyn Demskyi

.64

MAINTAINING THE MENTAL HEALTH OF THE BORDER GUARDS IN SPECIAL AND/OR EXTREME CONDITIONS OF THEIR PROFESSIONAL ACTIVITY BY MEANS OF THE PASTORAL ACTIVITY OF THE MILITARY CHAPLAINS Artem Makovskyi 
THEORETICAL AND METHODOLOGICAL APPROACHES

TO OPERATIONALIZATION OF THE CONCEPT

OF "PERSONAL RESOURCES" IN PSYCHOLOGY

Anatolii Yakymchuk ........................................................................................ 110

PROFESSIONAL REFLECTION IS A FACTOR

OF IMPROVING THE TEACHER'S PROFESSIONALISM

Tetiana Scherban

SURVEY RESULTS ON MILITARY LEADER'S ABILITIES

TO CREATE GENDER-SENSITIVE ENVIRONMENT

Olena Volobuieva . 152 
DOI https://doi.org/10.36059/978-966-397-152-0/1-21

\section{THE SIGNIFICANCE OF PROBLEM-SOLVING IN THE PROFESSIONAL ACTIVITY}

\section{Maryna Smulson}

\section{INTRODUCTION}

The aim of the article is to show the place of a problem in the structure of professional activity as well as psychological problems of training personnel for setting and solving professionally-oriented problems. We onward rely on the elaborations of the Ukrainian scientists, which were called "problem-based approach to the activity". Corresponding researches were initiated at H. S. Kostiuk Institute of Psychology at the National Academy of Pedagogical Sciences of Ukraine in the early 1970-s under the direct leadership of H. Kostiuk and V. Glushkov. In this direction, many interesting theoretical and applied projects have been carried out, in particular, by G. Ballom, T. Gergey, O. Dovgiallo, Yu. Mashbits, M. Smulson, O. Stognii, E. Yushchenko and other Ukrainian psychologists and cyberneticists. According to the problem-based approach, any activity of the subject, in particular professional one, can be described as a system of processes for solving problems of different sorts and types. A problem is a unit of activity that displays all of its features, from the motive to the problem-solving tools and relative operations. Therefore, according to S. Maksimenko, a problem is a "universal technique of organizing human activity".

In the professional activity, we first of all distinguish problems concerning career, which clearly correspond to the meaning and purpose of the professional activity (for example, didactic problems for the teacher, research - for the scientist, legal - for the lawyer, etc.).

1 Maksymenko, S. D. (2019). Aktualni problemy henetychnoi psykholohii [Actual Problems of Genetic Psychology] Aktualni problemy psykholohii: Zb. nauk. prats Instytutu psykholohii imeni H. S. Kostiuka NAPN Ukrainy. [Actual problems of psychology: Collection of scientific works of the H.S. Kostiuk Institute of Psychology of the National Academy of Pedagogical Sciences of Ukraine.] T. U111, Psykholohichna teoriia $\mathrm{i}$ tekhnolohiia navchannia [Psychological Theory and Technology of Learning], vol. 10., Kyiv., S. 15 [in Ukrainian]. 
At the same time, accomplishing a professional activity is impossible without solving problems that fall within organizing activity, including joint tasks as well as personal interaction and interaction of professional groups, and, surely, the tasks of professional selfimprovement, that is, professional self-design and self-development. Definitely, there are many more types of problems in professional activity. However, essentially all problems, as shown below, grow out of problem situations and require intellectually creative efforts, in other words, make professional activities intellectually rich.

\section{General Characteristics of the Problem-Based Approach to the Activity. Task and Intellect}

The well-known definition of the problem proposed by G. Ball is based on the concept of 'system, 2,3 " A problem, in its most general form, is a system whose obligatory components are a) an object of the problem, which is in the initial state (hereinafter, the original object of the problem); b) a model of the desired state of the object of the problem (we identify this model with the requirement of the problem)" ". To define a problem, which is considered as such a system, G. Ball uses the term 'problem system'. Evidently, the problem is interpreted by G. Ballom quite broadly, and such an interpretation is necessary to construct the concept of a problem approach to the activity.

Justifying this concept, G. Ball writes: "If the concept of a problem is interpreted quite broadly, then the activity of the subject can be represented as a system of processes for solving problems. We emphasize that this applies not only to the regulatory but also to the

2 Ball, G. A. (1990) Teoriia uchebnykh zadach: Psikhologo-pedagogicheskii aspekt [Theory of Educational Problems: Psychological and Pedagogical Aspect]. M.: Pedagogika. $184 \mathrm{~s}$.

${ }^{3}$ Ball, G. A. (2019). Bazovyie poniatiia obshchei teorii zadach. [Basic Concepts of the General Theory of Problems.] ... // Aktualni problemy psykholohii: Zb. nauk. prats Instytutu psykholohii imeni H. S. Kostiuka NAPN. Vol. U111, Psykholohichna teoriia i tekhnolohiia navchannia [Psychological Theory and Technology of Learning], vol. 10. Kyiv, 33-55. [in Russian]

4 Ball, G. A. (1990) Teoriia uchebnykh zadach: Psikhologo-pedagogicheskii aspekt [Theory of Educational Problems: Psychological and Pedagogical Aspect]. M. : Pedagogika. S. 31. 
creative components of the activity: the problems, actually solved by the subject, express not only the external demands placed on him, but also the strand of his personality. Highlighting the problems that are being solved by the subject, as well as the means and ways of solving them, establishing the qualitative and quantitative characteristics of these tasks help research and design activities. In particular, the possibilities of distinguishing their age, individual and other peculiarities, comparison of problems, actually solved by the subject with the problems that are set before them or are to be solved by them in this situation are extending"5.

G. Ball distinguishes a problem-system from a problem situation (a set of objects that admits a system representation as a problem but has not yet received such a representation) and a sign model of the problem, in particular, its verbal description (formulation of the problem).

In its turn, the system that provides the solution to the problem, in an extended sense, is called the solver by G. Ball. He borrowed the term from cybernetics. Therefore, he notes that animals, humans, groups of people, technical devices and others can act as solvers. Essentially, he proposes to characterize the solver by the set of problem-solving means, he / she has at his disposal. The problems are proposed to be considered both taking into account the characteristics of the solver as well as abstracting from them ${ }^{6}$.

It is implicitly considered that the solver and the problem raiser are different systems (people, groups, technical devices, etc.). It is clear that this situation certainly takes place when learning problems are solved, when the problems for a student are selected or created by the teacher precisely to train the use of appropriate problem-solving tools. However, this is only one of the possible options. The article

5 Ball, G. A. (1990) Teoriia uchebnykh zadach: Psikhologo-pedagogicheskii aspekt [Theory of Educational Problems: Psychological and Pedagogical Aspect]. M.: Pedagogika. P. 5-6.

6 Ball, G. A. (1990) Teoriia uchebnykh zadach: Psikhologo-pedagogicheskii aspekt [Theory of Educational Problems: Psychological and Pedagogical Aspect]. M.: Pedagogika. $184 \mathrm{~s}$.

7 Ball, G. A., Margulis, Ye. D., Rybalka, V. V., Chmut. T. K., Samoylov, A. Ye. (1983). Issledovaniia protsessa postanovki zadachi i ikh pedagogicheskoye znacheniye [Investigations of the Problem Setting Process and Their Pedagogical Significance]. // Programmirovannoye obucheniye [Programmed Training]. Vyp. 20. Kiyev. 
analyzes relevant experimental studies conducted by colleagues under the guidance of G. Ball, investigates the process of setting mental and organizational problems within the framework of fulfilling practical tasks that are set outside. These are service situations for checking the availability of a tool given to two employees of different shifts (T. Chmut's research); tasks for operating computers (O. Samoilov's research); design problems (V. Rybalka's research) and tasks for setting problems in group work (E. Margulis's research). In the last study, in particular, the focus was on setting group-specific tasks and its organization. It was found out that such problems were not spotted or actualized by pairs, but sometimes were spotted in the group of three people, however were often ineffectively solved, that is, the resolution activities were carried out by one or two tested persons, and the third was passively awaiting the results.

Although, relevant researches were conducted more than thirty years ago and bears convincing evidence about the importance of setting problems without any assistance for the evolvement of cognitive activity and creative initiative, it can have been stated so far that "relevant skills are purposefully formed neither in secondary school, nor in the vocational education system, nor in higher education establishment" ${ }^{\text {" }}$.

However, in the traditions of H. Kostiuk's scientific school, it is necessary to build psychological and pedagogical approaches taking into account their developmental potential and possibilities of further enrichment and modernization $9,10,11$. G. Ball rightly

${ }^{8}$ Ball, G. A., Margulis, Ye. D., Rybalka, V. V., Chmut. T. K., Samoylov, A. Ye. (1983). Issledovaniia protsessa postanovki zadachi i ikh pedagogicheskoye znacheniye [Investigations of the Problem Setting Process and Their Pedagogical Significance]. // Programmirovannoye obucheniye [Programmed Training]. Vyp. 20. Kiyev. [in Russian]

${ }^{9}$ Kostiuk, H. S. (1969). Princip razvitiia v psihologii [The Development Principle in the Psychology]. Metodologicheskiie i teoreticheskiie problemy psihologii [Methodological and Theoretical Problems of Psychology]. M. : Nauka [in Russian].

10 Maksymenko, S. D. (2019). Aktualni problemy henetychnoi psykholohii [Actual Problems of Genetic Psychology] Aktualni problemy psykholohii: Zb. nauk. prats Instytutu psykholohii imeni H. S. Kostiuka NAPN Ukrainy. [Actual problems of psychology: Collection of scientific works of the H. S. Kostiuk Institute of Psychology of the National Academy of Pedagogical Sciences of Ukraine.] T. U111, Psykholohichna teoriia $\mathrm{i}$ tekhnolohiia navchannia [Psychological Theory and Technology of Learning], vol. 10., Kyiv. 8-20 [in Ukrainian]. 
points out that problems (sign models of problems), which have the same normative meaning, do not always have the same meaning for the solver" ${ }^{12}$ In this respect, we recollect the concept of "additional definition" of a problem, introduced by Y. Mashbits ${ }^{13}$, according to which, under the influence of various intellectual and motivational factors, a student transforms a specified external problem into a problem in a psychological sense, that is, not only spots an object but also comes to grips with his / her own learning activities. "A problem additional definition can be pictured as a projection of actualized goal-drives for a subject at a specified moment (they reflect both the personal meaning of the students and certain situational factors), as well as the intellectual properties (abilities, knowledge and skills, subjective world as a whole) to an externally set task" ". An additional definition and even a new definition of the problem contribute to the development of the person, who solves the problem (the solver), that is, it can facilitate the achievement of learning goals, especially distant ones, such as the development of cogitation, imagination, reflection as well as students' own activity mastery.

However, in our opinion, the most effective in terms of selfeducation and accordingly intellectual self-development is the situation

11 Chepelieva, N. V. (2019). Rozviazannia smyslovykh zadach yak chynnyk samoproektuvannia osobystosti [Solving Meaningful Problems as a Factor of SelfDesign of Personality]. Aktualni problemy psykholohii: Zb. nauk. prats Instytutu psykholohii imeni H. S. Kostiuka NAPN Ukrainy [Current Problems of Psychology: a collection of scientific works of H. S. Kostiuk Institute of Psychology of the National Academy of Pedagogical Sciences of Ukraine]. T. U111, Psykholohichna teoriia i tekhnolohiia navchannia [Psychological Theory and Technology of Learning], vol. 10. K., P. 300-313 [in Ukrainian].

${ }^{12}$ Ball, G. A. (2019). Bazovyie poniatiia obshchei teorii zadach. [Basic Concepts of the General Theory of Problems]. ... // Aktualni problemy psykholohii: Zb. nauk. prats Instytutu psykholohii imeni H. S. Kostiuka NAPN. Vol. U111, Psykholohichna teoriia i tekhnolohiia navchannia [Psychological Theory and Technology of Learning], vol. 10. Kyiv, 33-55. [in Russian]

13 Mashbyts, Yu. I. (2019). Psykholohichni mekhanizmy i tekhnolohiia navchannia [Psychological mechanisms and technology of teaching]. K.: Interservis [in Ukrainian].

14 Mashbyts, Yu. I. (2019). Psykholohichni mekhanizmy i tekhnolohiia navchannia [Psychological mechanisms and technology of teaching]. K.: Interservis [in Ukrainian]. S. 33. 
of self-assignment when the problem-maker and problem-solver is one and the same person, that is, they merge into one person, who finds for himself / herself a specified (problem) situation. This person constructs its sign model (transforms into a problem) and then solves the problem according to their own systems of tools, sometimes creatively developing and supplementing them.

Based on the problem-based approach, we believe that intellectual activity is initiated (triggered) in a problem situation, which transforms into a task when it is independently set. Any situation, whether practical or theoretical, can be defined as a problem one, which has no obvious decision fitting the circumstances and that is why it requires ground state and cogitation. Depending on how the situation is perceived by the subject, the problem setting either takes place or does not.

A problem setting stage needs consideration in all tasks, but especially in those that arise in practical work. Detection of a future problem - a problem situation - is one of the most important properties of an expert's intellect. The problem situation is often not fully recognized and exists to the extent that the person, who invented it, has something to with it.

The problem differs from the problem situation as it is recognized by the subject, objectified and most often described verbally or in a different sign (numeric, graphic) form. The problem statement contains its analysis and understanding at a certain level, preliminary definition of the decision conception, strategy, action plan. It usually involves consideration of possible realistically available problem solving tools (ie material, materialized and ideal objects that do not directly enter the conditions of the problem but are involved in solving it) ${ }^{15}$.

Therefore, a problem, that is, its independent statement, is an ontological substrate for such metacognition, which we call intellectual initiation ${ }^{16}$. We are not inclined to agree with M. Kholodnaia's critics of problems as the ones that deontologizes

15 Smulson, M. L. (2003). Psykholohiia rozvytku intelektu: monohrafiia [Psychology of Development of Intellect: Monograph], K. : Nora-Druk[in Ukrainian].

${ }^{16}$ Smulson, M. L. (2009). Intelekt i mentalni modeli svitu [Intellect and Mental Models of the World] / Naukovi doslidzhennia kohnityvnoi psykholohii [Scientific and Cognitive Psychology]. Ostroh: Vyd-vo Natsionalnoho universytetu "Ostroh", Vol. 12, 38-49 [in Ukrainian]. 
intellect $^{17}$. She believes that the problem-based approach specific for intelligence scale is diagnosed not by the type of intellectual organization but by the problem-dependent response style. In other words, fair criticism here is limited to a wrong emphasis on the result rather than the process and the apparent artificiality of the test tasks, but one cannot agree that the problem is the one, which deontologizes the intellect. In our opinion, the task itself neither detect, nor diagnose intellect, nor deontologizes it in any way, it launches it, that is, initiates intellectual activity. Moreover, we use the term "problem" as a basic semantic construct in defining intellect and analyzing the process of its development. From our point of view the intellect is a holistic (integral) mental formation that is responsible for the creation, construction and restructuring of mental models of the world by setting and solving problems (for more information about the significance of the problem in intellectual activity ${ }^{18}$ ).

In the context of professional activity, we consider the mental model of the world as the result of intellectual processing (reflection, awareness, fixation and interpretation) by a professional of personal experience, recorded in a reduced form (for example, in the form of self-narrative). Mental models capture the content and level of understanding of a person's self, others and the environment, closely related to knowledge and beliefs, so they can be considered as a stable intellectual characteristic of a professional. A serious transformation of the mental model system is usually interpreted as a sign of selfmovement and self-development.

On the other hand, the mental model can be regarded as a kind of interpretation filter. The basic directions of constructing a mental model are the sense or, otherwise, the value-oriented basis (life, one's own professional activity, etc.), the chronotope, or temporal-spatial

17 Kholodnaia, M. A. Psikhologiya intellekta [Psychology of Intelligence]. Paradoksy issledovaniia [Paradoxes of Research]. Moskva-Tomsk: Izd-vo Tom. un-ta, 1997. $392 \mathrm{~s}$.

${ }^{18}$ Smulson, M. L. (2017). Mistse zadachi v intelektualnii diialnosti // Pedahohika i psykholohiya: Visnyk NAPN Ukrayiny [The Place of the Problem in Intellectual Activity // Pedagogy and Psychology: Bulletin of the National Academy of Pedagogical Sciences of Ukraine]. № 2 (95). S. 40-48. 
coordinates, as well as an aspect of a significant other (others, reference group) as an interactive (decentralized) substructure of the mental models ${ }^{19}$.

The structure of intellect is formed by the basic mental processes, that is, the system of cognitions, as well as metacognitions: intellectual initiation (self-assignment), decentralization, reflection and strategic fit ${ }^{20}$.

They are their own, independently set problems that initiate the development and self-development of intellect. Used as a problem, all structural components of intellect, both cognitive and metacognitive ones, interact and integrate, enter into a coalition at every timepoint, providing appropriate amplification and transformation of mental models of the world.

The dynamics of metacognitions determine the potential for the development and self-development of intellect as a whole. At the same time, as we stated above, intellectual initiation corresponds to the independent formulation of the problem, and the intellect develops best if the problem is independently spotted and assigned. To launch the intellectual processes, it is necessary to have a problem that the subject feels, sees, etc., turns it into a task and begins to work on it, to solve it.

A. Karpov ${ }^{21}$, explaining the special role of metacognitive processes in the structure of consciousness, notes that they are all aimed at organizing, regulating, and coordinating others - the "primary" cognitive processes. Therefore, metacognitive processes are such procedural means that, by mastering them, the subject largely becomes the one, that is, he / she acquires "self" and subjectness not

19 Smulson, M. L. (2019). Rozvytok dorosloi liudyny u suchasnomu tranzytyvnomu sviti [Adult development in the modern transitive world]. Aktualni problemy psykholohii: Zb. nauk. prats Instytutu psykholohii imeni H.S.Kostiuka NAPN Ukrainy [Current problems of psychology: a collection of scientific works of the H.S. Kostiuk Institute of Psychology of the National Academy of Pedagogical Sciences of Ukraine]. T. U111, Psykholohichna teoriia i tekhnolohiia navchannia [Psychological theory and technology of teaching], vol. 10, Kyiv, 257-267 [in Ukrainian].

20 Smulson, M. L. \& oth. (2015). Intelektualnyi rozvytok doroslykh u virtualnomu osvitnomu prostori: monohrafiia [Adult intellectual development in the virtual educational space: a monograph]. Kyiv : Pedahohichna dumka. URL: http://lib.iitta.gov.ua/10064. [in Ukrainian].

21 Karpov, A. V. (2011). Psikhologiia soznaniia: Metasistemnyi podkhod [Psychology of Consciousness: Metasystem Approach]. M.: RAO. 1088 s. 
only in relation to the external world, but also in relation to the inner world - one's own psyche, its contents.

In this concept, intellect is the only one, there is no schematic, social, emotional, professional or any other intellect. This understanding is in line with the B. Teplov's principle of unique intellect $^{22}$. The problems that intellect fulfills at each particular time are different. The development of intellect is that it is enriched, amplified, that is, metacognitions begin to actively work with the new problems, for example, not only with the professional, but also with those a person faces in the society, or vice versa.

\section{Psychological Principles of Pre-Starting Procedure for Solving Professional Problems}

Both cognitions and metacognitions have fundamental differences when it comes to the professional, true-to-life problems, on the one hand and learning ones, on the other hand. In view of this, Y. Kornilov notes that when comparing specific features of professional and trueto-life problems (multifacetedness, continuity, dynamics, immensity, efficiency, irreversibility) with the features of common learning problems it becomes clear that the latter are characterized by contradictions. (one-sidedness, discontinuity, static character, readability, inactivity, reversalness $)^{23,24}$.

Learning problem, even if taken from the professional sphere or from real life, is discharged of the special bonds which it has been associated with, respectively, with the career process or with life. It is, as already stated, was given to the student externally, and therefore he

22 Teplov, B. M. (1961). Um polkovodtsa [The Mind of the Commander]. I B.M.Teplov // Problemy individual'nykh razlichiy [Problems of Individual Differences]. M.: APN RSFSR. S. 252-344.

23 Kornilov, Yu. K. (1997). O razlichiiakh metakognitsii uchebnoy i professionalnoi deiatelnosti [About the Differences in Metacognitions of Educational and Professional Activities]. // Kognitivnoie obucheniie: sovremennoie sostoianiie i perspektivy [Cognitive Learning: Current Status and Prospects]. / Pod red. T. Galkinoy i E. Lourera. M.: Izd-vo «Institut psikhologii RAN». S. 191-200.

${ }^{24}$ Kornilov, Yu. K. (2014). Na puti k psikhologii prakticheskogo myshleniia [On the Way to the Psychology of Practical Thinking]. M.: Izd-vo «Institut psikhologii RAN». $407 \mathrm{~s}$. 
is not required to find the problem on his / her own. Therefore, the learning problem does not teach the student the most important skill of the problem-based approach to activity - the "art" of seeing the problem. On the other hand, standard learning activity prepares itself for error-free activity, extremely strictly treating any student error in solving the problem.

According to $\mathrm{Yu}$. Mashbits ${ }^{25}$ learning problems are fundamentally different from production, professional ones. They occupy a specific place in the activity. In any work activity, both production as well as theoretical and cognitive ones, the solution of the problem is the purpose of the activity and acts as its direct product. However, in learning activity, the result of problem solving does not make sense in itself, apart from the problem solving process as an indicator of its progress. So, in the learning activity, problem solving is not its goal, but a means of achieving a goal.

However, how can you teach a professional without going through a training phase, solving a job's professional problems?

There is a serious and difficult to solve problem: how to eliminate this rigid opposion of the learning and the real problems, the approximation of the relevant metacognitions. The fundamental point in this aspect is the orientation of the psychological and pedagogical content of the learning problems (ie, the methods of action and strategies) at the corresponding content of the real ones.

It is worth reminding that the basic characteristic of intellectual initiation we consider subjectness and independence, that is, the impulse to tackle the difficult true-to-life or professional problem, looking for resources to solve it and analyzing not only the result, but also the process of achieving this result. At the same time, the fundamental and very interesting moment of the modern decisionmaking concept in complex and complicated situations is the refusal to focus on error-free activities.

25 Mashbyts, Yu. I. (2019). Psykholohichni mekhanizmy i tekhnolohiia navchannia [Psychological mechanisms and technology of teaching]. K.: Interservis [in Ukrainian]. 
G. Klein ${ }^{26}$ refers to D. Kahneman's research on decision-making in an uncertain situation ${ }^{27,28}$, noting that they have become of particular importance now, in the new century, because it is clear that people do whatever it takes to solve problems and make decisions in the real life. They do not generate alternatives, they do not estimate their probabilities, they do not weigh the advantages and disadvantages to compare these alternatives, they do not build decision trees although such strategies are considered to be the most rational. In other words, the classic normative approach to decision-making does not provide an understanding of how expert professionals act in making urgent decisions in complex situations, which are certainly linked to crisis true-to-life and professional conditions.

That is why a new paradigm has emerged that considers decision-making in unique situations of extreme professional activity, known as "naturalistic decision making"29, 30. The main characteristic of the approach is, first of all, the rejection of generalized abstract decision-making models, since expert's decisions depend on the unique features of the particular situation. The options available to the subject are unknown and are being opened during the problem solving process.

The person in the problem solving process does not compare the options, if he / she immediately finds an alternate that leads to a satisfactory solution, then in times of scarcity, he / she uses it (because the situation may change irreversibly during reflection).

${ }^{26}$ Klein, G. (2008). Naturalistic Decision Making. Human Factors / Klein G. // The Journal of the Human Factors and Ergonomics Society. 50(3). P. 456-460.

27 Kaneman, D. (2014). Dumai medlenno... reshai bystro [Think Slowly ... Decide Fast]. / Daniel Kaneman M.: AST. - 315 s. [in Russian].

28 Kaneman, D., Slovik, P., Tverski, D. (2018). Prinyatiie reshenii v neopredelennosti. Pravila i predubezhdeniya [Decision Making in Uncertain Situations: Rules and Biases]. KH. : Izd-vo «Gumanitarnyi Tsentr». $536 \mathrm{~s}$. [in Russian].

${ }^{29}$ Klein, G. (2008). Naturalistic Decision Making. Human Factors / Klein G. // The Journal of the Human Factors and Ergonomics Society. 50(3). P. 456-460.

${ }^{30}$ Knauff, M., Wolf, A. G. (2010). Complex Cognition: the Science of Human Reasoning, Problem-Solving, And Decision-Making / Knauff M., Wolf A. G. // Cognitive Processesing. 11 (2) P. 99-102. 
And again: there is no point in finding deviations from normative models and interpreting them as erroneous. O. Poddiakov ${ }^{31}$, analyzing this approach, notes that "in situations of high complexity, the very concept of error becomes ambiguous; it loses the meaningfulness and clarity of the criteria for distinguishing between errors and no mistakes... In general, under unstable conditions, rigid attitudes towards error-free activity are not adaptive".

On the other hand, activities under the circumstances of the guideline removal of infallibility also imply a high level of subjectness, that is, the willingness to be responsible for both self-selected, assigned and solved problems, as well as for the irreversible results of the choices and decisions made.

Thus, we have demonstrated that in a specifically organized learning activity under the conditions of intellectual training ${ }^{32}$, this disagreement is removed to some extent.

Our learning problems designed for training acquire the main features of true-to-life problems - namely, multifacetedness, continuity, dynamics, immensity, efficiency. However, it is obvious that in a safe artificial training environment, learning problems could not acquire implementation-related features, that is their irreversibility, which promotes high responsibility for intellectual activity.

We describe the features of intellectual training as an environment for learning to set and solve professional tasks ${ }^{33}$. One of the fundamental properties of an intellectual training environment is its intellectual saturation, which is achieved by creating problem situations of different content and structure and building appropriate psychotechnical procedures on their basis.

31 Poddiakov, A. N. (2015). Psikhologiia obucheniia v usloviiakh novizny, slozhnosti, neopredelennosti [Yelektronniy resurs] [The psychology of Learning in the Context of Novelty, Complexity, Uncertainty [Electronic resource]. / A. N. Podd'yakov // Psikhologicheskiye issledovaniya [Psychological research]. T. 8, № 40. S. 6. URL: http://psystudy.ru

32 Smulson, M. L. (2003). Psykholohiia rozvytku intelektu: monohrafiia [Psychology of Development of Intellect: Monograph], K. : Nora-Druk [in Ukrainian].

33 Smulson, M. L. (2003). Psykholohiia rozvytku intelektu: monohrafiia [Psychology of Development of Intellect: Monograph], K. : Nora-Druk [in Ukrainian]. 
It is worth reminding that $\mathrm{G}$. Ball ${ }^{34}$ distinguishes the problem from the problem situation - a set of objects that allows a systematic representation in the form of a problem, but the one that has not yet received such representation.

He also distinguishes the problem from its sign model, the partial case of which is a verbal description (formulation).

We call a problem any situation, practical or theoretical, in which there is no obvious appropriate to circumstances decision and that is why it requires a break and consideration. Depending on how the situation is perceived by the subject, problem setting either takes place or does not take its place in the task ${ }^{35,36}$. We can assume that the transition from a problem situation to a problem is caused by a special manifestation of the subject's vigorous actions - excessive situative activity, which characterizes the tendency of the subject to act above the threshold of external or internal situational need, or go beyond the initial situation ${ }^{37}$.

V. Petrovsky distinguishes two levels of such activity: the phenomenon of "excessive situationality", that is, the redundancy of the subject's actions with respect to the requirements of the situation, which determine the criteria for the effectiveness of his behavior and are taken as initial ones, and "counter-situationality" when the subject acts contrary to incentives that restrict his / her free development. The main feature of the phenomena of excessive situational activity is that "the subject, acting in the direction of realization of the initial requirements of the situation, goes beyond these requirements; activity

${ }^{34}$ Ball, G. A. (2019). Bazovyie poniatiia obshchei teorii zadach. [Basic Concepts of the General Theory of Problems.] ... // Aktualni problemy psykholohii: Zb. nauk. prats Instytutu psykholohii imeni H. S. Kostiuka NAPN. Vol. U111, Psykholohichna teoriia i tekhnolohiia navchannia [Psychological Theory and Technology of Learning], vol. 10. Kyiv, 33-55. [in Russian]

35 Smulson, M. L. (2003). Psykholohiia rozvytku intelektu: monohrafiia [Psychology of Development of Intellect: Monograph], K. : Nora-Druk[in Ukrainian].

36 Poddiakov, A. N. (2015). Psikhologiia obucheniia v usloviiakh novizny, slozhnosti, neopredelennosti [Yelektronniy resurs] [The psychology of Learning in the Context of Novelty, Complexity, Uncertainty [Electronic resource]. / A. N. Podd'yakov // Psikhologicheskiye issledovaniya [Psychological research]. T. 8, № 40. S. 6. URL: http://psystudy.ru

${ }^{37}$ Petrovskiy, V. A. (1992). Psikhologiya nadadaptivnoi aktivnosti [Psychology of Adaptive Activity]. M.: TOO «Gorbunok» [in Russian] 
moments appear at the same time as if they were separated and not related to the facts of the subject "exit" beyond the situation boundaries" 38 . Such "exit beyond" the problem situation is observed, in our opinion, in case of the subject (group) transition to independent problem setting and attempts to solve it.

The problem-setting stage needs to be considered in all problems, but especially in those that arise in practical work. Finding a future problem - a problem situation - is one of the most important properties of an expert's intellect.

The problem differs from the problem situation in that it is consciously recognized by the subject, objectified and most often described verbally or in another sign (numeric, graphic form). The problem setting contains its analysis and understanding at a certain level, preliminary definition of the conception of the decision, strategy, and action plan. It, as a rule, involves taking into account the possible realistically available problem solving means (ie. material, materialized and ideal objects that are not directly included in the conditions of the problem, but are involved in solving it).

Hereafter, the stage of building problem structure is highlighted as the most important stage of the solving process ${ }^{39}$. A problem structure is understood a well-ordered model of a problem situation, which includes ideal objects, their functions, purpose (the ordering operation separates the desired objects from the data in the condition). This issue is called differently: understanding the problem, building a problem situation model and so on. According to many studies, this aspect plays an important role in the process of solving any problem. Apart from the very issue of constructing (detecting) a problem structure, the issue concerning the means of its explicit description, as well as some formalized "language" for such a description are equally important. Adequate language of the problem structure promotes the convergence of objective and subjective problem structures.

${ }^{38}$ Petrovskiy, V. A. (1992) .Psikhologiya nadadaptivnoi aktivnosti [Psychology of Adaptive Activity]. M.: TOO «Gorbunok». S. 15. [in Russian].

39 Mashbyts, Yu. I. (2019). Psykholohichni mekhanizmy i tekhnolohiia navchannia [Psychological mechanisms and technology of teaching]. K.: Interservis [in Ukrainian]. 
This gave us a reason to highlight the construction and description in a special formalized "language" of the problem structure in designing problem solving processes as intellectual activity as a separate sub-problem, and in terms of formation - learning an effective strategy for building a problem structure (along with the subsequent learning of an effective strategy to transform the problem structures). As for the descriptive "language" of a problem structure, it must become an integral part of the whole set of tools for solving similar problems.

Thus, intellectual training can be argued that it provides cooperative learning activity with its main attributes: free exchange of thoughts, creative character of search, interdependence and interresponsibility, reflection of one's own and partners' activity, management of one's own and partners' activity, etc.

In addition, it provides an opportunity to construct the learning process so that the direct product of students' activities is not the digestion of certain content, which in the context of traditional learning meets the closest learning goals, but the formation of those abilities that correspond to the components of our intended intellect in their interconnection. The construction of the educational process is aligned with the experimental and genetic method, because, firstly, it is based on a model (project) of the psychological phenomenon, which must be formed. Secondly, it provides other regularities of students' activity and development of projected ability in comparison with the patterns in traditional learning. Thirdly, the development of this psychological phenomenon in the conditions of experimental training, built according to the model (project) and theoretical ideas about the learning process is investigated. Fourthly, the design of our training process concerning preparation for the problem solution allows us to construct the educational process so that those psychological abilities that in the conditions of traditional training meet the distant goals, in the experimental training act as those that meet its immediate goals.

\section{CONCLUSIONS}

All in all, the practical implementation of the designed educational process requires a fundamentally new approach to building an educational impact system as a way of managing learning activities. The learning impact system was organized into a learning environment 
that we called intellectually rich, since the learning impacts were aimed at setting and solving intellectual problems. The most important features of such an environment are that it is characterized by such features as the problematicity and uncertainty of the environment, over-objectivity of the environment, the metacognitive nature of the environment, the processivity of the environment, the intellectual potentiality of the environment, the integrative and activity nature of the environment. In addition, the activity in the environment is invaluable, tolerant, that is, in intellectual training the concept of error, evaluation - neither process nor result - by other participants or the trainer is not used, except self-evaluation and one's own comparison with one's objective results. Fluid and crystallized intellect interact in the environment, which is achieved through inclusion of experts' groups of all ages. Decentrality and group nature of the environment should also be noted. The implementation of these characteristics acted as certain requirements for the project development of the environment.

Means of providing, ie creation and maintenance, project characteristics in the real training process are multifunctional problem situations and psychotechnical procedures are designed on their basis. Intellectual saturation of the environment is achieved by introducing to it specially designed (sprout) problem situations of different content and structure and constructing appropriate psychotechnical procedures on their basis. It is a fundamental moment in designing and maintaining the problematicity of the environment, because in this approach the problem situations are really only "potential problems", and the elements of vision, reconstruction, minimization-deployment of problem situations and tasks in the multi-vector field of professional activity are simulated in the environment.

The environment, designed in this way, enables the extension of problem types used in it as well as the predominant orientation to setting and solving non-standard problems, namely: problems for setting problems and moving from a problem situation to a problem using different "languages" of its description, problems on reflection, problems concerning the situation forecast and transformation, situations concerning one's own and partners' activity management as well as joint activity organization, etc. Intellectual activity in the environment when solving any problem requires constant 
metacognitive monitoring advanced intellectual and interpersonal ("inter-intellectual") reflection. In other words, constructing a "world of problems", one's own intellectual and partners' activities takes place in the environment, which contributes to the amplification and transformation of mental models of the world ${ }^{40,41,42}$.

\section{SUMMARY}

In the problem-based approach to activity, proposed by $\mathrm{H}$. Kostiuk and his followers, activity is seen as a system of problem solving processes. In order to start (initiate) a professional activity, the problem, which the subject feels, sees, etc., turns into a task and begins to work on it, to solve it, is nessecery. This situation of self-assignment of the professional problem has the greatest effectiveness in terms of self-study and, accordingly, professional self-development.

The modern process of preparation for professional activity focuses primarily on situations of high complexity and involves a high level of independence and subjectness of the student, in particular, in setting and solving problems in the activity; reorganization of systems of learning problems to approximate them to the real ones and, accordingly, orient them to the requirements of multifacetedness, continuity, dynamics, immensity, efficiency, etc.; refusal from the rigid guidance on the error-free activity; special work on the development of self-search skills and setting tasks in the activity. These aspects of preparation for problem solving in a professional activity are effectively realized through the use of intellectual training, ie specially organized group work on setting and solving different types of professional problems.

40 Smulson, M. L. (2003). Psykholohiia rozvytku intelektu: monohrafiia [Psychology of Development of Intellect: Monograph], K. : Nora-Druk[in Ukrainian].

${ }^{41}$ Smulson, M. L. (2009). Intelekt i mentalni modeli svitu [Intellect and Mental Models of the World] / Naukovi doslidzhennia kohnityvnoi psykholohii [Scientific and Cognitive Psychology]. Ostroh: Vyd-vo Natsionalnoho universytetu "Ostroh", Vol. 12, 38-49 [in Ukrainian].

42 Smulson, M.L. \& oth. (2015). Intelektualnyi rozvytok doroslykh u virtualnomu osvitnomu prostori: monohrafiia [Adult intellectual development in the virtual educational space: a monograph]. Kyiv : Pedahohichna dumka. URL: http://lib.iitta.gov.ua/10064. [in Ukrainian]. 


\section{REFERENCES}

1. Ball, G. A. (2019). Bazovyie poniatiia obshchei teorii zadach [Basic Concepts of the General Theory of Problems.] ... // Aktualni problemy psykholohii: Zb. nauk. prats Instytutu psykholohii imeni H. S. Kostiuka NAPN. Vol. U111, Psykholohichna teoriia i tekhnolohiia navchannia [Psychological Theory and Technology of Learning], vol. 10. Kyiv, 33-55. [in Russian].

2. Ball, G. A., Margulis, Ye. D., Rybalka, V. V., Chmut. T. K., Samoylov, A. Ye. (1983). Issledovaniia protsessa postanovki zadachi i ikh pedagogicheskoye znacheniye [Investigations of the Problem Setting Process and Their Pedagogical Significance]. // Programmirovannoye obucheniye [Programmed Training]. Vyp. 20. Kiyev. S. 39-47. [in Russian].

3. Ball, G. A. (1990) Teoriia uchebnykh zadach: Psikhologopedagogicheskii aspekt [Theory of Educational Problems: Psychological and Pedagogical Aspect]. M.: Pedagogika. 184 s. [in Russian].

4. Chepelieva, N. V. (2019). Rozviazannia smyslovykh zadach yak chynnyk samoproektuvannia osobystosti [Solving Meaningful Problems as a Factor of Self-Design of Personality]. Aktualni problemy psykholohii: Zb. nauk. prats Instytutu psykholohii imeni H. S. Kostiuka NAPN Ukrainy [Current Problems of Psychology: a collection of scientific works of H. S. Kostiuk Institute of Psychology of the National Academy of Pedagogical Sciences of Ukraine]. T. U111, Psykholohichna teoriia i tekhnolohiia navchannia [Psychological Theory and Technology of Learning], vol. 10. K., P. 300-313 [in Ukrainian].

5. Kaneman, D. (2014). Dumai medlenno... reshai bystro [Think Slowly ... Decide Fast]. / Daniel Kaneman. M.: AST. 315 s. [in Russian].

6. Kaneman, D., Slovik, P., Tverski, D. (2018). Prinyatiie reshenii $\mathrm{v}$ neopredelennosti. Pravila i predubezhdeniya [Decision Making in Uncertain Situations: Rules and Biases]. KH. : Izd-vo "Gumanitarnyi Tsentr". 536 s. [in Russian].

7. Karpov, A. V. (2011). Psikhologiia soznaniia: Metasistemnyi podkhod [Psychology of Consciousness: Metasystem Approach]. M.: RAO. 1088 s. [in Russian]. 
8. Kholodnaia, M. A. Psikhologiya intellekta [Psychology of Intelligence]. Paradoksy issledovaniia [Paradoxes of Research]. Moskva-Tomsk: Izd-vo Tom. un-ta, 1997. 392 s. [in Russian].

9. Klein, G. (2008). Naturalistic Decision Making. Human Factors / Klein G. // The Journal of the Human Factors and Ergonomics Society. 50(3). P. 456-460. [in English].

10. Knauff, M., Wolf, A. G. (2010). Complex Cognition: the Science of Human Reasoning, Problem-Solving, And DecisionMaking / Knauff M., Wolf A.G. // Cognitive Processesing. 11 (2). P. 99-102.

11. Kornilov, Yu. K. (2014). Na puti k psikhologii prakticheskogo myshleniia [On the Way to the Psychology of Practical Thinking]. M.: Izd-vo "Institut psikhologii RAN". 407 s. [in Russian].

12. Kornilov, Yu. K. (1997). O razlichiiakh metakognitsii uchebnoy i professionalnoi deiatelnosti [About the Differences in Metacognitions of Educational and Professional Activities]. // Kognitivnoie obucheniie: sovremennoie sostoianiie i perspektivy [Cognitive Learning: Current Status and Prospects]. / Pod red. T. Galkinoy i E. Lourera. M.: Izd-vo "Institut psikhologii RAN". S. 191-200. [in Russian].

13. Kostiuk, H. S. (1969). Princip razvitiia v psihologii [The Development Principle in the Psychology]. Metodologicheskiie i teoreticheskiie problemy psihologii [Methodological and Theoretical Problems of Psychology]. M. : Nauka [in Russian].

14. Maksymenko, S. D. (2019). Aktualni problemy henetychnoi psykholohii [Actual Problems of Genetic Psychology] Aktualni problemy psykholohii: $\mathrm{Zb}$. nauk. prats Instytutu psykholohii imeni H. S. Kostiuka NAPN Ukrainy. [Actual problems of psychology: Collection of scientific works of the H.S. Kostiuk Institute of Psychology of the National Academy of Pedagogical Sciences of Ukraine.] T. U111, Psykholohichna teoriia i tekhnolohiia navchannia [Psychological Theory and Technology of Learning], vol. 10., Kyiv., 8-20 [in Ukrainian].

15. Mashbyts, Yu. I. (2019). Psykholohichni mekhanizmy i tekhnolohiia navchannia [Psychological mechanisms and technology of teaching]. K.: Interservis [in Ukrainian]. 
16. Petrovskiy, V.A. (1992) .Psikhologiya nadadaptivnoi aktivnosti [Psychology of Adaptive Activity]. M.: TOO "Gorbunok" [in Russian].

17. Poddiakov, A. N. (2015). Psikhologiia obucheniia v usloviiakh novizny, slozhnosti, neopredelennosti [Yelektronniy resurs] [The psychology of Learning in the Context of Novelty, Complexity, Uncertainty [Electronic resource]. / A. N. Podd'yakov // Psikhologicheskiye issledovaniya [Psychological research]. T. 8, № 40. S. 6. URL: http://psystudy.ru [in Russian].

18. Smulson, M. L. (2003). Psykholohiia rozvytku intelektu: monohrafiia [Psychology of Development of Intellect: Monograph], K. : Nora-Druk [in Ukrainian].

19. Smulson, M. L. (2009). Intelekt i mentalni modeli svitu [Intellect and Mental Models of the World] / Naukovi doslidzhennia kohnityvnoi psykholohii [Scientific and Cognitive Psychology]. Ostroh: Vyd-vo Natsionalnoho universytetu "Ostroh", Vol. 12, 38-49 [in Ukrainian].

20. Smulson, M. L. \& oth. (2015). Intelektualnyi rozvytok doroslykh u virtualnomu osvitnomu prostori: monohrafiia [Adult intellectual development in the virtual educational space: a monograph]. Kyiv : Pedahohichna dumka. URL: http://lib.iitta.gov.ua/ 10064. [in Ukrainian].

21. Smulson, M. L. (2019). Rozvytok dorosloi liudyny u suchasnomu tranzytyvnomu sviti [Adult development in the modern transitive world]. Aktualni problemy psykholohii: Zb. nauk. prats Instytutu psykholohii imeni H.S.Kostiuka NAPN Ukrainy [Current problems of psychology: a collection of scientific works of the H. S. Kostiuk Institute of Psychology of the National Academy of Pedagogical Sciences of Ukraine]. T. U111, Psykholohichna teoriia i tekhnolohiia navchannia [Psychological theory and technology of teaching], vol. 10, Kyiv, 257-267 [in Ukrainian].

22. Smulson, M. L. (2017). Mistse zadachi v intelektualnii diialnosti // Pedahohika i psykholohiya: Visnyk NAPN Ukrayiny [The Place of the Problem in Intellectual Activity // Pedagogy and Psychology: Bulletin of the National Academy of Pedagogical Sciences of Ukraine]. № 2 (95). S. 40-48. 
23. Teplov, B. M. (1961). Um polkovodtsa [The Mind of the Commander]. / B. M. Teplov // Problemy individual'nykh razlichiy [Problems of Individual Differences]. M.: APN RSFSR. S. 252-344. [in Russian].

\section{Information about the author:}

Maryna Smulson

Doctor of Psychological Sciences, Professor,

Real member of National Academy of Pedagogical Sciences of Ukraine,

Head of Department of Modern Information Technologies of Education, G. S. Kostiuk Institute of Psychology, National Academy of Pedagogical Sciences of Ukraine 2 Pankivska str., Kyiv, 01033, Ukraine ORCID ID: orcid.org/0000-0002-9563-3390 E-mail: smulson@ukr.net 


\section{PROFESSIONALISM OF ENGINEERS-BORDER GUARDS AS A FACTOR TO ACCOMPLISH THEIR SERVICE DUTIES}

\section{Mykhailo Tomchuk}

\section{INTRODUCTION}

An important state task in the war in the east of Ukraine is the training of highly qualified specialists in the security and defense sector. Such a national task is successfully solved by the staff of the National Academy of State Border Guard Service of Ukraine (NASBGSU), providing professional training of cadets for future professional activity at the border. The formation of the competence and professionalism of future officers is directly connected with the development of their readiness to solve various tasks on the protection of the State Border of Ukraine. The professionalism of cadets-border guards, as an indicator of their personal readiness to complete their assignments, is formed at the academy as a special institution of higher education (HEI), in a holistic, integrated educational process. The level of professionalism depends on the objective (external) conditions, namely on the content and orientation of the educational process, the qualification of scientific and pedagogical staff, and on the individual characteristics of the cadets, their sensitivity, ability to learn, motivation, ability to regulate their mental conditions, behavior in the conditions of future extreme activity at the border, etc.

It is of scientific and practical interest to study the dynamics of personal readiness development to solve professional problems in the educational process of the State Border Guard Academy and in the process of adapting its graduates to real professional activity at the border. The development of components of person's professionalism, depending on the professional orientation of young people is still underdeveloped in psychology. That is why we have carried out a comparative analysis of the levels of development of individual components of professionalism in boys and girls studying in the academy and in humanitarian HEI. In the researches concerning the mentioned problem, insufficient attention is paid to the formation of professionalism of cadets-border guards - future engineers of the State 
Border Guard Service of Ukraine. They carry out the tasks that are relevant to the state: engineering support of the state border protection, maintaining communication between the border guard units, their software and technical service, etc.

The service of officers-engineers at the border takes place in special, conditions, requiring rapid adaptation of equipment, special devices to combat use, readiness for operational intellectual activity, planning, assumptions, making optimal decisions.

The young border guard-officer also needs a long time to adapt to the real life at the border, to fulfill his or her professional duties. The success of their adaptation is conditioned by the peculiarities of the development of the necessary personal, professionally significant qualities in the HEI.

The complication of the professional activities of military engineers at the border in the current environment requires the maximum use of content, innovative technologies for training the cadets to develop them as a creative personality, an individual who has prospects for improvement and is able not only to assess their capabilities adequately, but also to use them rationally in the future activities.

That is why the proposed study is devoted to theoretical and experimental analysis of the peculiarities of the development of border guard-engineers' professional readiness to solve their tasks.

\section{Professionalism as readiness of a person for professional activity}

Methodological basis in the process of studying the problem of professional forming of future engineers - the border guards-cadets was a personal activity, systematic approach. According to the activity approach (M. Ya. Basov, Ye. O. Klimov, O. M. Leontiev, S. L. Rubinshtein, V. D. Shadrikov, etc.), in the process of professional formation under the influence of educational, subject and professional activity, the border guard's personality changes, his motivation, competence, self-awareness.

Depending on the content and focus of training, a certain type of professional personality is formed at the National Academy of the State Border Guard Service of Ukraine, for example, future 
engineering officers show a slightly greater tendency to intellectual, technical activity.

The professional development of the individual is a two-sided process: firstly the profession, which is chosen, and the educational process in the HEI influence the development of the individual, and then the specialist make alterations to the professional activity at the state border.

According to the representatives of the systematic approach (L. K. Velitchenko, Yu. P. Povarionkov, V. V. Rybalka, etc.), professional formation of a person can be considered as a system "subject of work - professional activity". Thus, the psychological functional system of activity consists of motives of professional activity; goals that are related to the activity result, programs, information bases of the activity; decision making and subsystems of professionally important qualities. The structure of the subsystem of professionally important qualities changes and the level of their integration increases depending on the stage of professional formation $^{2}$. Professional formation is a dynamic systemic multilevel process: at its first level, mechanisms of socialization and individualization are studied; on the second - elements of the life path of the individual; on the third - mechanisms of development and learning; on the fourth - a form of personality activity. Professional formation of a person depends on social factors, professional abilities, professional experience, acceptance of "professionalization as a life task"3. An indicator of the person's professionalism is his readiness for professional activity. That is why we plan an experimental study of individual indicators of the border guards-engineers' readiness development to solve their service tasks: activity motives, volitional traits, qualities, etc.

${ }^{1}$ Povarenkov Yu. P. (2002). Psykholohycheskoe soderzhanye professyonal'noho stanovlenyya cheloveka [Psychological content of professional formation of a person]. Moscow: Publishing House of URAO. [in Russian]

${ }^{2}$ Shadrikov V. D. (1996). Psykholohyya deyatel'nosty y sposobnosty cheloveka [Psychology of human activity and ability]. Moscow: Logos Publ. [in Russian]

${ }^{3}$ Povarenkov Yu. P. (2002). Psykholohycheskoe soderzhanye professyonal'noho stanovlenyya cheloveka [Psychological content of professional formation of a person]. Moscow: Publishing House of URAO. [in Russian] 
Within the systematic approach, scientists distinguish the components of professional activity: needs, motives, subject matter, information base, purpose, tools, social environment and subject. In accordance with this model, a two-dimensional model of personality (subject of professional activity) is revealed, the personality's structure of general psychological properties has been revealed in the following dimensions: social-psychological and individual (psychosociality, capability to communicate, determination, character, self-awareness, experience, intellect, psychophysiology, psychosomatics) and activity (need-motivational, informative-cognitive, goal-forming, operationaleffective, emotional-sensual components) ${ }^{4}$.

The person formation in a professional activity, success is largely dependent on an adequate comparison of oneself, one's own achievements in the profession with those ones of others. The professional activity of a specialist in the subjective dimension and, accordingly, its formation is revealed through the achievement of professional suitability, through readiness for activity, which implies the subject's compliance with its requirements. The stages of professional formation are: preparation for the profession, option, vocational training, mastery of professional activity, skills, leaving the profession. We consider that very important periods are the choice of profession, vocational training and the stage of mastering and adapting to it. The subject of our study is to study the peculiarities of professionalization of cadets in the educational process of HEI and in the process of adaptation and mastery of graduates with professional engineering activities in the initial period of service at the border.

Professional development is understood as the formation of a set of integrated personality characteristics: professional orientation, competence, socially and professionally important qualities, as well as its readiness for constant professional growth, finding the correspondence between individual-personality characteristics and the nature of pursuing professional activity with the aim of more qualitative and creative approach to its implementation. During the implementation

${ }^{4}$ Rubalka V. V. (2014). Psykholohiya ta pedahohika pratsi osobystosti: vid obdarovanosti dytyny do maysternosti dorosloho [Psychology and pedagogy of the work of the individual: from the gifted child to the skill of the adult]. Kyiv: Institute of Gifted Child Publ. [in Ukrainian] 
of professional activity, there is an interaction of the person and the profession, which causes the corresponding changes: on the one hand, under the influence of activity, a person changes, on the other hand - the nature and content of the profession transforms. The main contradiction contributing to the development of personality is the mismatch between the requirements of the profession and the available personality traits. Therefore, with the inclusion of a person in professional activity is enriching his psyche due to the formation of complexes of qualities. Determinants of professional formation are external influences (socioeconomic conditions) and internal conditions (peculiarities of the psyche of the individual, his social and professional experience). The decisive importance in professional development belongs to professional activity, which depends on the quality of professional activity, getting pleasure from it, the pace of professional growth, the possibility of overcoming professional crises, etc. 5

The crises overcoming in ontogenesis is caused by the driving forces of personality development, provided they are resolved productively. We believe that the subject of activity for effective professional development must go through overcoming contradictions and crises. Much of this depends on the activity of the individual, the level of his motivation to perform professional activity, readiness for self-realization and so on.

The study of the psychological structure of activity, including the professional one, helps to solve extremely important methodological and practical problems and answer the following questions: 1) how the objective world transforms during the active intervention of a person to perform professional activity; 2) how a person changes during the performance of a certain activity; 3) the appearance of the psychological structure of any particular professional activity; 4) how the activity influences the development of human capabilities and how the activity itself becomes individual ${ }^{6}$.

${ }^{5}$ Zeer E. F. (2009). Psykholohyya professyonal'noho obrazovanyya [Psychology of Professional Education]. Moscow: IT Academy Publ. [in Russian]

6 Bodrov V.A. (2007). Psykholohycheskye osnovy professyonal'noy deyatel'nosty [Psychological bases of professional activity]. Moscow: PERSE Publ. [in Russian] 
Typical tasks and skills are identified for each profession, which imply not only specific professional knowledge, skills, but also professionally important personality traits (PITs). Today, in our opinion, it is important to distinguish the concepts of professional competencies of the engineer, which imply not only his knowledge, skills, abilities, but also the ability to use them in new non-standard conditions, to include the intelligent, volitional qualities to solve pressing problems of engineering activities.

In general, in the readiness for professional activity of a future engineer, the following components can be distinguished: motivational, cognitive, individual-typological, operational-procedural and emotional-volitional, which have their own characteristics. Each component of the professionalism of a future engineer is characterized by specific features. Thus, the motivational component includes the presence of developed motivation to obtain professional knowledge and skills, mastering engineering activities, and expressed motives (creative implementation, motivational units for military service, process, educational and cognitive motives, etc.), also an important aspect is the ability to set an adequate goal and find the means to achieve it, and in general, to the profession as a satisfying one.

The cognitive component is primarily the knowledge of the profession of military engineer, professional intelligence (technical thinking, imagination), which have specific properties that allow you to solve engineering problems, and its structure includes the idea of themselves in the profession as such characteristics, which imply awareness, interpretation, self-description and situations that occur around you. The individual-typological component contains the typological and characterological properties of the engineer's personality, including PSF. Emotional-volitional readiness is characterized by the personality's ability to manifest volitional qualities, stress resistance, self-regulation of behavior and activity, emotional states in conditions of high extremality of activity at the border. In operational readiness, the skills and competencies, which are necessary for the border guard, are singled out, the ability to use professional experience in border operations; personal potential that determines the effective performance of professional tasks; creativity that provides high-quality non-template solution to professional problems. 
Thus, under the professionalism of future military engineers we understand the psychological formation of a cadet's personality, which is an integrative characteristic of a subject of engineering activity, the basis of which is professional authenticity, which contains not only professional competence but also reflects a high level of development of professionally important qualities, which provide professionally important qualities, progressive development of future border guards of engineering and technical specialties at the stage of vocational training.

\section{Psychological analysis of the activities of border guard-officers of the engineering direction}

The professional engineering of officers at the border is complex and multifunctional. Readiness for it is enshrined in the educational process at NASBGSU. The development of future border guards-engineers is ensured in the course of mastering the cadets in 1-2 courses of knowledge and skills in general and humanities, basic disciplines and, above all, in mathematics, physics, materials science, material resistance, electrical engineering, etc. Based on this, they master the basics of content and organization of transportations, economics of operation and military repair of equipment in the State Border Guard Service, organization of economic work in the military unit on the operation and repair of motor vehicles, transportation, technical and economic indicators of technical condition and works of motor transport, use of the main production assets of the unit, use of its working capital, economics of material-technical security basics reduce the cost of operation and repair of automotive and special equipment etc.

The special task of training border guards is to teach them the features of the organization, the operation of weapons and equipment, and the order and analysis of the reliability of the basic samples of border equipment. In terms of content, such training includes the features of the operation of weapons and special equipment, the operation and accounting of motor vehicles, the control of the state of arms and military equipment at the border, theoretical foundations and the calculation of indicators of their reliability.

The border guard-engineer must also have good knowledge of the basics of engineering support for the protection of the state border at 
the sector of the border guard detachment and the use of technical means of monitoring it. He must be well-informed in the basic types of technical support for units (tank, artillery, etc.). In terms of content, this involves knowledge of the basics of tank and technical support, the features of weapons and equipment in the conduct of hostilities, methods of planning repair of weapons and equipment in the conduct of combat operations, the evacuation of weapons and equipment, providing armed vehicles and equipment, units of the border guard detachment, general provisions on artillery and technical support, system of providing troops with rocket artillery and ammunition, bases of artillery and technical support of troops, provision of parts of missile and artillery weapons and ammunition in the main types of combat, artillery and technical support of the border guard detachment, engineering and technical support in main types of combat actions.

The general actions and actions of border guards include: deciding on the use of force and means; planning of border protection measures; setting tasks for border guards to protect the state border; organization of management, interaction and comprehensive support; preparation of detachments to repel enemy attacks and support them in constant combat readiness, control over the implementation of all border protection measures in the conditions of hybrid war and others.

The combat service of the border guards and, above all, the officers, involves performing difficult functions related to the high efficiency, dynamic action of the units, maintenance and use of sophisticated modern equipment, automated control systems, information processing and intelligence.

Particularly specific in terms of psychology is the organization of combat service of military personnel in extraordinary circumstances. It covers a number of such basic measures: assessment of the current situation, determination of the required number of forces and means for defense, use of the State Border Guard Service of Ukraine (SBGSU) with the highest efficiency, etc.

Educational function of the service and combat activity of the officer of the SBGSU is to train personnel in the actions during the performance of combat tasks, actions on alarms: to organize and conduct tactical and tactical-special, instructive training with personnel, which have details, use weapons and military equipment, summarize the combat service in the unit, prepare and conduct training 
with military personnel on combat readiness, constantly check the status of combat readiness of those techniques and weapons in the assigned units, use in the military service different types and forms of training and education of subordinates.

Service-combat activity is also characterized by complex conditions, which are naturally reflected on the mental level of the individual in the form of anxiety, fears, stresses, etc. The reasons for the appearance of such conditions of the border guards are:

1) suddenness, unexpectedness of occurrence and manifestation of different situations of combat service;

2) threat to the person's normal life and health;

3) danger to life and health;

4) unusuality and novelty of situations;

5) uncertainty (complete or partial lack of information, inconsistency of the combat situation);

6) redundancy of information (in case of excess of information on certain events of the phenomenon, there is a need for deep and accurate analysis and drawing of adequate conclusions);

7) lack of time (to analyze, evaluate the situation, make decisions and take specific actions, as border guards have very little time in comparison with the usual conditions of activity);

8) responsibility (for the execution of orders, according to the statutes, employees are legally responsible; in addition, they are charged with high social, moral responsibility for their actions and actions);

9) awareness of the SBGSU personnel of the special nature and results of combat service;

10) officers, ensigns, and soldiers endure prolonged difficulties, discomfort, and sometimes even indignation associated with the lack of proper living conditions.

Such activity is intense and places special demands on the emotional-volitional sphere of the individual. According to M. I. Diachenko, V. O. Ponomarenko and others, situations of special stress can be characterized by the following types (quoted $\mathrm{in}^{7}$ ):

7 Tomchuk M. I., Matohniuk L. O. (2012). Formuvannya psykholohichnoyi hotovnosti osobystosti do inzhenernoyi diyal'nosti na zanyattyakh z matematyky [Formation of psychological readiness of an individual for engineering activities in mathematics classes]. Vinnitsa: Publisher FOP Rogalskaya I. O. [in Ukrainian] 
1. Rapid situation. The activity is carried out in the conditions of severe shortage of time with the maximum mental load, the readiness of the person for immediate action at an extremely fast pace. Such situations in combat activity are characterized by unexpectedness, speed of occurrence and course, lack or contradiction of information, intensity of intellectual functions (thinking, imagination and others).

2. Long-lasting. In such a situation, high physical and mental endurance, mobilization, responsibility and autonomy are important for military personnel. These are situations in anticipation of certain behavior of border violators, etc.

3. The situation with the element of uncertainty. In such a situation, the military man faces the problem of choosing the only correct solution from several possible equally socially significant options.

4. A situation that requires an individual's readiness for urgent, operational action. In this situation, special requirements are taken into account, the speed of psychic functions, emotional balance.

5. Situation related to the receipt of false information. The way out depends on the amount of such information, the availability of time to process it and the professional experience of the border guard.

6. The situation of a "dominant state" in the activity of a military man is related to his being in a state of weak reaction to the teams, signals that can lead to negative consequences of the activity.

7. Critical situation. It occurs in extreme cases of activity of military personnel and gives them an alternative choice of possible results of activity: victory or complete defeat. In such a situation, all the possibilities and reserves of the individual are revealed, and their adaptive capabilities are revealed. Such situations are a criterion for checking the military personnel for their position, social status.

That is why the important task of forming the cadets' psychological readiness for future activity at the border is the formation of the necessary volitional qualities, the ability to selfregulate their states, behavior under different conditions of professional activity mentally.

Psychological analysis of the modern activities of the border guard shows that it can be presented to some extent as human life in special, more extreme, compared to his activity in many other areas, conditions of existence. This is a strictly regulated and controlled 
activity of the individual. It goes with certain moral, social, temporal, spatial, and more restrictions. In the service itself, formal relations are strictly and normatively regulated, employees are not allowed to be members of any parties, they cannot participate in the work of various mass meetings, organizations, societies.

In today's SBGSU, compared to the past times, there are significant changes in the direction of its decision:

1) the share of mental labor in use has increased due to its greater intellectualization and new scientific research, scientific and technical developments, means implementation;

2) certain reorganizational changes in the structure, the content of the activity of different SBGSU units;

The activity of the SBGSU has its specific socio-psychological features, which largely determine and require complication of the subjective psychological structure of the activity of the border guard's personality.

They are the following:

1) great social and state importance of the activity;

2) high physical, intellectual and emotional tension, pace and dynamics of the service;

3) more rigid, in comparison with other professions, the regulation and legal regulation of the relations between its participants;

4) the ability to perform duties in different climatic, weather, time intervals, etc.;

5) high degree of collective activity;

6) high level of organization of relationships vertically and horizontally;

7) frequent change of some activities, actions to others, which may be caused by different operational situation, etc.

Subjective conditions for pursuing professional activity at the border should also include the level of personal awareness of one's mental properties, qualities, degree of development of mental cognitive processes, emotional and volitional sphere, psychomotor, the level of knowledge, skills, and in general - abilities, which allow for timely and adequate conclusions.

The SBGSU officers should have a well-formed organizational component of the activity, which is revealed in the following features: 
1) self-organization, manifested in discipline, proper distribution of time, clear fulfillment of various duties;

2) organization of activities of other persons, who perform homogeneous or different functions in the team;

3 ) organizing and coordinating the activities of other units, institutions that perform service functions in certain situations.

Military engineers create, maintain in working order military machines, mechanisms, devices, process various materials. They must be able to understand the drawings and diagrams, to represent not only the device and the static state of the mechanism, machine, but also the process of working interaction, the movement of their elements, parts. It is important to be able to build versions of the possible causes of disorders, problems, and in the imagination to reproduce the search options, highlighting the most likely, and, most of all, in the special conditions of activity. Particularly sophisticated knowledge is required in the field of properties of objects of work, conditions and means of their transformation, it is also important to know perfectly the structure and functions of used military machines, devices, tools. It is necessary to have a lot of knowledge and quantitative indicators related to the modes of operation of equipment, its operation, working conditions. High demands apply to all forms and types of memory, thinking. Especially often requires a clear imaginary operation of objects in space, understanding the principles of operation, operation of machines, mechanisms, circuits, electronic and electrical devices. Military engineers are also appreciated for their ability to make optimal decisions in the short term. It requires emotional restraint, stability in emergencies, increased sense of responsibility (the cost of error when working with equipment is very high).

As a result of the survey of graduates of the Academy (more than 200 people), we can distinguish the following features of the professional activities of border guard-engineers: mental load, creativity, experience and knowledge, organization, initiative, autonomy, responsibility. However, the productivity of professional activities of engineers, largely depends on their personal, including volitional qualities, on the degree of their formation and manifestation. Among the professionally important personal qualities of engineers we have identified such as: readiness for independent work, professional communication, working capacity, self-organization, self-improve- 
ment, self-control, creative, spatial imagination, a tendency for technical creativity, tension, self-regulation, courage in making; promptness; teamwork, organization, discipline; compromise thinking, the ability to find an alternative between the idea of designers and the real possibilities of implementation of this idea in life; accuracy, attentiveness; stress resistance; persistence; engineering thinking.

The performance of the engineering activity is realized through the implementation of production functions that are generally typical of the engineer. They include:

1. Research, which is related to the implementation of research works, work with scientific materials and literature;

2. Design, which involves the development and design of new types of products, improvement of equipment and decision-making methods;

3. Technological, which is associated with the choice of technological process, control of the production process, in general with the control of technological systems.

Understanding these functions ensures the implementation of the professional program of the engineer. An important element of the psychological structure of engineering activities is decision making and their possible correction. This is due to the development of mental self-regulation of the personality of the officer of his volitional qualities. The study of these features, among others, will be the subject of an experimental study of future engineers and young border guards.

\section{Experimental study of the readiness of border guards for professional engineering activities}

For the purpose of experimental study of the peculiarities of personal readiness for professional engineering activity, we selected a set of methods and techniques, which included: observations, interviewing methods (questionnaires, interviews), testing. The sample consisted of: 100 cadets - future engineers of NASBGSU, 100 officers-engineers - graduates of the National Academy of the State Border Guard Service of Ukraine, for a term of up to 5 years of service and students of mechanical engineering of the city of Vinnytsia (100 persons). The study was conducted in 2018-2019. 
According to the methodology presented in ${ }^{8}$, the structure of motivation that encourages cadets-border guards and students of 2-3 courses to study at the HEI was researched. (Table 1). As can be seen from Table 1, there are some differences in the structure of motivation for choosing a profession among students of future mechanical engineers and cadets of NASBGSU. On the positive side, most young people consider studying at the HEI a condition for personal development (professional, intellectual, physical, strong-willed, etc.). However, such a group of motives is much more important in cadets than in students. As for the motivation of the prestige of the engineering profession, it is also much higher among the students of NASBGSU, compared with the students of civil defense.

\section{Features of development in youth motivation to choose the profession of engineer}

\begin{tabular}{|l|c|c|}
\hline \multirow{2}{*}{ Groups of motives } & \multicolumn{2}{|c|}{ Youth category in\% } \\
\cline { 2 - 3 } & $\begin{array}{c}\text { Mechanical Engineering } \\
\text { students } \\
(\mathbf{n = 1 0 0 )}\end{array}$ & $\begin{array}{c}\text { Students-border } \\
\text { guards } \\
(\mathbf{n = 1 0 0})\end{array}$ \\
\hline Socially significant & 35 & 42 \\
\hline $\begin{array}{l}\text { Motives for improving the } \\
\text { personality }\end{array}$ & 54 & 68 \\
\hline $\begin{array}{l}\text { Motives for the prestige } \\
\text { of the profession }\end{array}$ & 26 & 54 \\
\hline Material motives & 19 & 42 \\
\hline Secondary motives & 26 & 32 \\
\hline
\end{tabular}

Civil engineering (profession - mechanical engineer) does not enjoy high prestige among young people today, which is probably due to their awareness of employment problems, future career prospects etc. Future border guards-engineers are slightly higher than those of civilians are, and have material motives, due to some differences in their payment. The remuneration of border guards is far higher than that of civil engineers today.

8 Tomchuk M. I., Matohniuk L. O. (2012). Formuvannya psykholohichnoyi hotovnosti osobystosti do inzhenernoyi diyal'nosti na zanyattyakh $z$ matematyky [Formation of psychological readiness of an individual for engineering activities in mathematics classes]. Vinnitsa: Publisher FOP Rogalskaya I. O. [in Ukrainian] 
The study examined the integral professionally important qualities of the personality of the border guard-engineers, namely their ability to creative self-realization, communicative competence, and the adequacy of professional self-esteem (Table 2).

The presence of one or another professionally important quality in the structure of the professionalism of an engineer does not indicate that the professional activity will be successful. These qualities should be developed by cadets in the educational process of NASBGSU and should have at the beginning of the service a level of development sufficient for professional activity.

Table 2

Formation of professionally important qualities in cadets (2-3rd years of studying) and young officers of border guard-engineers

\begin{tabular}{|c|c|c|c|c|c|}
\hline \multirow{2}{*}{$\begin{array}{c}\text { Professionally } \\
\text { important } \\
\text { qualities }\end{array}$} & \multirow{2}{*}{$\begin{array}{c}\text { Category } \\
\text { persons }\end{array}$} & \multicolumn{4}{|c|}{$\begin{array}{c}\text { Levels of development } \\
\text { of personality PVA (in \%) }\end{array}$} \\
\hline & & Low & Average & High & Very high \\
\hline \multirow{2}{*}{$\begin{array}{l}\text { Ability to } \\
\text { creative } \\
\text { self-realization }\end{array}$} & $\begin{array}{l}\text { The } \\
\text { cadets }\end{array}$ & 52 & 38 & 10 & 0 \\
\hline & $\begin{array}{l}\text { Young } \\
\text { officers }\end{array}$ & 10 & 62 & 12 & 16 \\
\hline \multirow{2}{*}{$\begin{array}{l}\text { Communicative } \\
\text { competence }\end{array}$} & $\begin{array}{l}\text { The } \\
\text { cadets }\end{array}$ & 14 & 44 & 30 & 12 \\
\hline & $\begin{array}{l}\text { Young } \\
\text { officers }\end{array}$ & 4 & 50 & 30 & 16 \\
\hline \multirow{2}{*}{$\begin{array}{c}\text { Adequacy } \\
\text { of professional } \\
\text { self-assessment }\end{array}$} & $\begin{array}{l}\text { The } \\
\text { cadets }\end{array}$ & 30 & 44 & 22 & 4 \\
\hline & $\begin{array}{l}\text { Young } \\
\text { officers }\end{array}$ & 4 & 32 & 54 & 10 \\
\hline
\end{tabular}

However, as can be seen from Table 2, the cadets' level of formation of such PITs is much lower than that of the young officers who actually serve at the border. It has been found that in the course of training at NASBGSU the cadets do not fully develop their abilities for creative selfrealization. This is especially true of junior cadets, whose rigorous statutory determination of activities at the academy does not fully create the space for the creative development and self-development of a future border guard-engineer officer. The cadets do not have the skills of creative 
self-realization, which should be laid in the process of circle, research, scientific and technical activity in HEI.

Almost every third border guard-cadet has also been found to have a low level of professional self-assessment adequacy. This is probably due to the lack of awareness of young men and women about the real service at the border, its identity requirements. Somewhat higher is the adequacy of professional self-assessment after the internship of cadets at regional offices of the State Border Guard Service. With the inclusion of the individual in the real engineering activity at the border, there are significant changes in the development and self-assessment of their PITs.

An important task of our study was to study the ideas of cadets and young border guards regarding professionally important qualities for the performance of their service tasks (the results of their study are shown in Table 3).

Table 3

Notions of future and young officers about the professional qualities of a border guard-engineer, which are important for the performance of their tasks

\begin{tabular}{|l|l|c|c|}
\hline $\begin{array}{c}\text { № } \\
\mathbf{S} / \mathbf{n}\end{array}$ & $\begin{array}{c}\text { Professional important } \\
\text { qualities of an engineer-officer } \\
\text { of the State Border Guard } \\
\text { Service of Ukraine }\end{array}$ & $\begin{array}{c}\text { Percentage } \\
\text { of mentioning } \\
\text { cadets-border } \\
\text { guards }\end{array}$ & $\begin{array}{c}\text { Percentage } \\
\text { of mentioning } \\
\text { officers-border } \\
\text { guards }\end{array}$ \\
\hline 1 & Technical and abstract thinking & 87 & 70 \\
\hline 2 & Memory & 56 & 52 \\
\hline 3 & Communication & 40 & 60 \\
\hline 4 & Attentiveness & 74 & 52 \\
\hline 5 & Self-regulation & 48 & 76 \\
\hline 6 & Responsibility & 65 & 88 \\
\hline 7 & Stress resistance & 44 & 85 \\
\hline 8 & Persistence & 34 & 72 \\
\hline 9 & Purposefulness & 42 & 76 \\
\hline 10 & Organizational skills & 74 \\
\hline
\end{tabular}

Border guards consider it important to be more strong-willed than intelligent when deciding on border guard tasks. The cadets have the willpower qualities, the ability of the officer's personality to self- 
regulation do not give much advantage. Realistically, more extreme than studying at the academy, the border guard service makes significant adjustments to the border guards' perceptions of the requirements it applies to all areas of the individual. Therefore, if the cadets ranked the intellectual qualities of the personality, then the young officers of the border guards ranked strong-willed qualities, qualities of self-regulation.

\section{CONCLUSIONS}

It can be concluded that in the conditions of training of cadets at the Academy it is extremely important to create situations in which they could create adequate ideas about professional activity at the border and the importance of making informed, volitional decisions by officers in various situations at the border.

\section{SUMMARY}

The article is devoted to theoretical and experimental analysis of the peculiarities of the development of border guard engineers' professional readiness to solve their official tasks. A comparative analysis of the levels of development of individual components of professionalism in young men and women studying at the academy and in humanitarian HEA has been carried out. It is argued that an indicator of the professionalism of a personality is its readiness for professional activity. That is why the authors present the results of an experimental study of individual indicators of the development of the readiness of border guards engineers to solve their tasks: motives, volitional traits, qualities, etc. The psychological analysis of the activity of the officers-border guards of the engineering direction is carried out. The special task of training border guards is to teach them the features of the organization, the operation of weapons and equipment, and the order and analysis of the reliability of basic models of border equipment. As a result of the survey of the graduates of the Academy, the features of the professional activity of frontier engineers (mental load, creativity, experience and knowledge, organization, initiative, independence, responsibility) are highlighted; the structure of motivation that encourages cadets, border guards and students of 2-3 courses to study at the WHO has been studied; Integrated professionally important qualities of the frontier engineer's personality were studied, namely their ability for creative self-realization, communicative competence, and adequacy of professional self-esteem. It is proved that in the conditions of training of cadets in the academy it is 
extremely important to create situations in which they would form adequate ideas about professional activity at the border and the importance of making informed, volitional decisions by officers in various situations at the border.

\section{REFERENCES}

1. Bodrov V.A. (2007). Psykholohycheskye osnovy professyonal'noy deyatel'nosty [Psychological bases of professional activity]. Moscow: PERSE Publ. [in Russian]

2. Zeer E. F. (2009). Psykholohyya professyonal'noho obrazovanyya [Psychology of Professional Education]. Moscow: IT Academy Publ. [in Russian]

3. Povarenkov Yu. P. (2002). Psykholohycheskoe soderzhanye professyonal'noho stanovlenyya cheloveka [Psychological content of professional formation of a person]. Moscow: Publishing House of URAO. [in Russian]

4. Rubalka V. V. (2014). Psykholohiya ta pedahohika pratsi osobystosti: vid obdarovanosti dytyny do maysternosti dorosloho [Psychology and pedagogy of the work of the individual: from the gifted child to the skill of the adult]. Kyiv: Institute of Gifted Child Publ. [in Ukrainian]

5. Tomchuk M. I., Matohniuk L. O. (2012). Formuvannya psykholohichnoyi hotovnosti osobystosti do inzhenernoyi diyal'nosti na zanyattyakh $z$ matematyky [Formation of psychological readiness of an individual for engineering activities in mathematics classes]. Vinnitsa: Publisher FOP Rogalskaya I. O. [in Ukrainian]

6. Shadrikov V. D. (1996). Psykholohyya deyatel'nosty $y$ sposobnosty cheloveka [Psychology of human activity and ability]. Moscow: Logos Publ. [in Russian]

\section{Information about the author: Mykhailo Tomchuk}

Doctor of Psychological Sciences, Professor, Senior Researcher of the Research Department National Academy of the State Border Guard Service of Ukraine named after Bohdan Khmelnytskyi 46, Shevchenko str., Khmelnytskyi, 29003, Ukraine ORCID ID: orcid.org / 0000-0002-4508-1495

E-mail: tomchukmi@gmail.com 


\section{PSYCHOLOGICAL PRINCIPLES OF SOLVING PROFESSIONALLY AIMED SITUATIONS IN THE PROCESS OF PROBLEM-BASED LEARNING}

\section{Artem Chornyi}

\section{INTRODUCTION}

The modern society raises new, higher demands on the professional competence of professionals. Professional activity requires a modern specialist to be competent in many issues, to be well versed in the character and behavior of a person, to be able to establish a favorable working atmosphere in the team, to maintain close cooperation with interacting structures, etc.

Among the professionally important qualities, the presence of which determines the success of the tasks, the ability to professional creativity is very important. Development and formation of sustainable skills for making creative and non-standard (atypical) decisions is one of the most important tasks of professional training at the present stage $^{1}$.

Problem-based learning has strong reservations about the professional competence of modern professionals, as it (along with traditional training) develops better in those who learn the ability to think creatively.

There is a need to investigate the features of the use of problembased training in the training of a modern specialist.

When organizing the process of learning, it is necessary first of all to create conditions that would cause cognitive activity of the listener. Only under this condition the learning process will proceed in accordance with the basic pattern of learning, as the satisfaction of the cognitive need that constantly arises in the listener.

${ }^{1}$ Shynkaruk O. M., Didenko O. V. (2017). Problem-based learning of border guards: theory, methodology, practice: a manual. Khmelnitsky: edition of the NASBGS, 67-68. [in Ukrainian]. 
One of the types of developmental learning, the essential difference of which is the convergence of psychology and thinking of a person with the psychology of the development of creative thinking of listeners is problem-based learning.

Overcoming intellectual difficulties and solving complex learning tasks stimulates the listener to a high level of development of thinking, creative opportunities and formation of a high level of professional competence.

\section{The psychological analysis of Problem-Based Learning (PBL) and its impact on creative activity development}

Nowadays it is impossible to overestimate the influence of PBL on development such distinctive features as creativity, broad-minding, good intellect etc.

PBL is a teaching method in which complex real-world problems are used as the vehicle to promote student learning of concepts and principles as opposed to direct presentation of facts and concepts. In addition to course content, PBL can promote the development of critical thinking skills, problem-solving abilities, and communication skills. It can also provide opportunities for working in groups, finding and evaluating research materials, and life-long learning ${ }^{2}$

PBL encourages students to apply their critical thinking and problem-solving skills to address real-world problems. It's a rich and engaging learning experience.

It differs from the traditional lecture-based approach, where teachers primarily provide students with information, also acting as facilitators who guide pupils through the learning process ${ }^{3}$.

PBL as a psychological-pedagogical strategy appeals to many educators because it offers an instructional framework that supports active and group learning-premised on the belief that effective learning takes place when students both construct and co-construct ideas through social interactions and self-directed learning. Its

2 URL: https://citl.illinois.edu/citl-101/teaching-learning/resources/teachingstrategies/problem-based-learning-(pbl). Problem-based learning teaching-strategies

3 URL: https://www.maastrichtuniversity.nl/education/why-um/problem-basedlearning. Problem-based learning. 
implementation can vary across institutions and programmes, but in general, it can be viewed as an iterative process made up of first, a problem analysis phase, a period of self-directed learning and lastly, a reporting phase. A tutor-also known as a facilitator-acts as a guide to scaffold students' learning, particularly in the problem analysis and reporting components of the PBL tutorial, as well as facilitate students' inquiry paths as they make sense of their ideas through discussion and sharing.

PBL has the potential to improve students' higher-order thinking skills, comprehension and application of knowledge, learning attitudes and motivation" and may also encourage students to accept more responsibility for their learning.

In a typical PBL setting, learning is triggered by a problem which needs resolution. Dewey explains the cognitive element of learner engagement by describing how the origin of thinking is some "perplexity, confusion, or doubt" that is triggered by "something specific which occasions and evokes it." Students make connections to this "perplexity, confusion, or doubt" by activating their individual and collective prior knowledge and finding resources to make sense of the phenomenon; they also engage in peer learning through small-group discussions and consolidate their learning through reflective writing. Beyond enabling students to make sense of the concepts and subject matter, this learning experience is also likely to help students "develop understandings of themselves and their contexts, and the ways and situations in which they learn effectively".

\section{PBL provides the following opportunities:}

- examine and try out what you know;

- discover what you need to learn;

- develop your people skills for achieving higher performance in teams;

- improve your communications skills;

- state and defend positions with evidence and sound argument;

- become more flexible in processing information and meeting obligations;

- practice skills that you will need after your education.

\section{PBL teaches to:}

- really understand the subject matter, rather just learning by rote; 
- collaborate with partners and small teams;

- think critically with a view to solving problems;

- study and work independently;

- feel comfortable with public speaking ${ }^{4}$.

PBL helps to develops critical thinking and creative skills, to improve problem-solving skills, increase motivation and to help students learn to transfer knowledge to new situations

The core problems will vary among disciplines. There are some characteristics of good PBL problems that transcend fields ${ }^{5}$ :

A. The problem must motivate students to seek out a deeper understanding of concepts.

B. The problem should require students to make reasoned decisions and to defend them.

C. The problem should incorporate the content objectives in such a way as to connect it to previous courses/knowledge.

D.If used for a group project, the problem needs a level of complexity to ensure that the students must work together to solve it.

E. If used for a multistage project, the initial steps of the problem should be open-ended and engaging to draw students into the problem.

The method for distributing a PBL problem falls under three closely related teaching techniques: case studies, role-plays, and simulations. Case studies are presented to students in written form. Role-plays have students improvise scenes based on character descriptions given. Today, simulations often involve computer-based programs. Regardless of which technique is used, the heart of the method remains the same: the real-world problem ${ }^{6}$.

We'd like to present the following steps in the PBL which characterize the whole process:

1. Read the problem and define any terms

2. Discuss the focus and the scope of the problem/scenario

${ }^{4}$ URL: https://www.studygs.net/pbl.htm. Problem-based learning (PBL) is an exciting alternative to traditional classroom learning.

${ }^{5}$ Duch B. J., Groh S. E. \& Allen D. E. (2001) The Power of Problem-Based Learning, New York Edition. 112-113.

${ }^{6}$ Molyako V. A. (2003) Schoolchildren psychology of creative problems solving. Kyiv: Glad. Publ. 78-79 [in Ukrainian]. 
3. Discuss the issues raised in the problem focus and their implication for the problem/scenario (Brainstorm the collective knowledge within the group about the issues)

4. Organize information into themes:

5. Set learning objectives

6. Access resources to answer learning objectives

7. Apply the knowledge to the problem scenario and feedback to the group and testing of new knowledge ${ }^{7}$.

Now, we'd like to mention the advantages of PBL, so they are as follows:

- it can encourage higher order critical thinking and deemphasize memorization;

- it can help student learn what is relevant to the real world;

- it can increase motivation to learn and arrive at a solution;

- it can provide opportunities for students to collaborate and practice their communication and social skills;

- it can help students understand how to learn ${ }^{8}$.

Education world suggests that teachers can implement PBL by getting students to work on problems affecting the neighborhood or school community, such as an ongoing litter problem, or by asking students to identify problems in the area, depending on their age and experience with problem-based learning ${ }^{9}$.

"Once you have selected a problem, gather your students to discuss project goals, deadlines and materials, and to brainstorm some action steps for the project. Make sure your assignment has no one right answer. Let your students drive the discussion and do the real, "messy" work-your job is to offer gentle direction and answer questions" $"$. Despite the potential benefits PBL can bring to the

7 URL: https://www.learning-theories.com/problem-based-learning-pbl.html. Problem-based learning learning-theories.

8 URL: https://www.forbes.com/sites/michaeltnietzel/2019/10/29/new-strongevidence-for-problem-based-learning/\#2f9c67e86ab8.New-strong-evidence-forproblem-based-learning.

9 URL: https://www.sciencedirect.com/science/article/pii/S2452301116300062. Problem-Based Learning: An Overview of its Process and Impact on Learning.

10 URL: https://www.studyinternational.com/news/problem-based-learning-inthe-classroom-yay-or-nay. Problem-based-learning-in-the-classroom-yay-or-nay. 
classroom, studies suggest that incorporating PBL can pose some teaching challenges.

In order to reach the full potential of PBL, the curriculum needs to be designed to meet the specific instructional needs and constraints of the students, such as their ability to be self-directed in their learning ${ }^{11}$.

Both teachers and students who are new to the responsibilities of this open-ended learning environment will need time to adjust to their changing roles, adding that studies suggest designing effective PBL problems is time-consuming and research-intensive process ${ }^{12}$.

This adds to teachers' stress levels, and potentially reduces their desire to implement PBL in the classroom. To boot, students who do not fare well in self-directed learning may pose another challenge.

\section{Psychological analysis of mechanisms for solving problem situations}

The main feature of problem learning is the deliberate use by the teacher of problem situations that arise out of his/her will (objectively) and situations created by them specifically.

The peculiarities of organizing the problem-based learning process are that the main element of the first and second stages of learning is the problem situation - the main means of activating students' mental activity.

There are two concepts in the literature on problem-based learning: "emergence" and "creation" of problem situations. First, a problematic situation for the listener always arises, for the teacher there are no problematic situations, there can be only methodological (psychological and pedagogical) difficulties ${ }^{13,14}$.

${ }^{11}$ URL: https://doi.org/10.1016/j.hpe.2016.01.004. The theory of problem-basedlearning.

${ }^{12}$ URL: https://www.wits.ac.za/therapeuticsciences/occupational-therapy/aboutus/problem-based-learning. Occupational-therapy.

${ }^{13}$ Bruner J. (1977). Psychology of knowledge. Beyond direct information. trans. from English. Moscow: Progress Publ. 223-224 [in Ukrainian]

${ }^{14}$ Grishko-Dunaevskaya V. A. (2016). Features of subject-subject interaction in the process of learning a foreign language in higher military educational institutions. Khmelnytskyi. : dissertation author's abstract on obtaining a scientific degree of candidate of psychological sciences, 6. [in Ukrainian]. 
Secondly, the problematic situation is generated by the educational or practical situation, the logic of the subject; they arise, as a rule, regardless of the desire of the teacher, i.e. objectively. Similarly, they can occur according to the logic of the educational process because of the rules of didactics of the sequence of actions of the teacher and the students. Typically, such situations are the result of the teacher asking questions or problems that prove to be problematic. However, the teacher may not even be aware of the psychological nature of this phenomenon ${ }^{15}$. Questions and tasks can be posed for a different purpose (to attract the attention of the listener, to find out if he has mastered the material, etc.), but, however, cause a problematic situation. Occurrence of it regardless of purposeful actions of the teacher is a completely natural phenomenon of the learning process ${ }^{16}$. Such situations, no doubt, activate the mental activity of the students, but this activation is not systematic, it has always been in the educational process. Problem situations can be created by the teacher intentionally, if he knows the rules of organization of problem-based learning ${ }^{17}$.

Purposeful use by the teacher of problem situations that arise in addition to his desire (objectively) and situations intentionally created by them, are a system whose skillful application is the main feature of problem-based learning and its difference from traditional one ${ }^{18,19}$.

The teacher A. M. Matyushkin formulated six rules for creating problem situations, four rules for managing the process of assimilation in a problem situation. These problem-based learning rules can serve

${ }^{15}$ Vygotsky L. S. (1982). The problem of will and its development in a child's age. Vol. 3, 452-455. [in Ukrainian].

${ }^{16}$ Antonenko T. L. (2019). Psychological bases of formation of value-semantic sphere of personality of the future specialist, K.: dissertation author's abstract on obtaining scientific degree of doctor of psychological sciences, 38-39. [in Ukrainian].

17 Ivanova L. (1988) Increasing of students' cognitive activity. Public education, 4. 42-47 [in Russian].

${ }^{18}$ Baranovska L. V. (2015). Pedagogy and Psychology of Higher School: Educ. Manual. Kyiv: NAS Publ. 223-225 [in Ukrainian].

19 Zhitko T. (2002). Learning Methods - Precondition for Intellectual Development of Personality. Native School, 6, 72-77 [in Ukrainian]. 
as didactic recommendations to the teacher in organizing the problembased learning process ${ }^{20,21}$.

Didactically and methodologically sound ways of creating problematic situations can be found only if the teacher knows the general patterns of their occurrence. There are attempts to formulate these patterns on problem-based learning in the literature in the form of types of problem situations ${ }^{22}$.

A broad typology of problematic situations was suggested by T. V. Kudryavtsev. As practice shows, all the diversity of contradictions contained in teaching material can be expressed by only a few types of educational problem situations as a more general concept of pedagogical psychology ${ }^{23}$.

As the studies have shown, we can distinguish the most typical two types of problem situations common to all subjects.

The first type should be considered the most common: the problem situation arises if the listeners do not know how to solve the task, cannot answer the problem questions, to explain the new fact in the educational or life situation, that is, if the students are aware of insufficient knowledge for an explanation of the new fact ${ }^{24}$.

The second type - problem situations arise when students are confronted with the need to use previously learned knowledge in new practical conditions. As a rule, teachers arrange these conditions not only to enable students to apply their knowledge in practice, but also to face the fact of their insufficiency. Awareness of this fact gives students a cognitive interest and stimulates the search for new knowledge $\mathrm{e}^{25,26}$.

${ }^{20}$ Matyushkin A. M (2003). Thinking, training, creativity. Moscow: Moscow Ed. Psychol. Soc. Inst; Voronezh: MODEK Publ. 615-616 [in Russian].

21 Matyushkin A. M. (1972). Problem situations in thinking and learning. Moscow: Pedagogy Publ. 78-80 [in Russian].

${ }^{22}$ Kostiuk, G. S. (1969). Princip razvitiya v psihologii [The principle of uncertainty in the psychology of choice and risk. Methodological and theoretical problems of psychology]. Moscow: Nauka Publ. [in Russian].

23 Kudryavtsev T. V. (1987). Issues of psychology and didactics of problem learning. Problem education. Moscow: Enlightenment Publ. 145-148. [in Russian]

${ }^{24}$ Ilnitskaya I. Ya. (1985). Problem situations and ways to create them in a lesson. Moscow: Knowledge Publ. 57-59. [in Ukrainian]

${ }^{25}$ Lerner I. Ya. (1974). Problem-based learning. Moscow. 128-129. [in Russian] 
The third type - a problem situation easily arises if there is a contradiction between the theoretically possible way of solving the problem and the practical impracticability of the chosen method.

The fourth type - a problematic situation arises when there is a contradiction between the virtually achieved result of the completion of the study task, the lack of knowledge of the students for its theoretical substantiation.

Opportunities to manage the learning process are that the problematic situation in its psychological structure has not only a substantively meaningful, but also a motivational personal side (the listener's interests, desires, needs, opportunities, etc.) ${ }^{27,28}$.

\section{The following didactic goals can be noted:}

a) to draw the listener's attention to the issue, the task, the educational material, to arouse his cognitive interest and other motives of activity;

b) to put him (her) in the face of such severe cognitive difficulties, which overcoming it would activate mental activity;

c) to open to the listeners the contradictions between the cognitive need and the impossibility of satisfying it, with the help of the available stock of knowledge, skills, habits;

d) to help him to identify in the cognitive task, issue, task the main problem and to outline a plan for finding ways out of the problem; to encourage the student to actively search;

e) to help him to update the previously learned knowledge and to show the direction of finding the most rational way out of the situation of difficulty ${ }^{29,30}$.

Based on the generalization of good pedagogical experience, there are several basic ways to deal with problem situations. These methods

${ }^{26}$ Makhmutov M. I. (1975). Problem-Based learning. Moscow. [in Russian]

27 Romanyuk I. M., Bogaychuk V. J. (2011). Problem studying-one of the effective methods of searching-cognitive activity of cadets (listeners), Bulletin of the National University of Defense of Ukraine, 6 (25). 47-55. [in Ukrainian]

${ }^{28}$ Smirnov S. D. (2003). Pedagogy and Psychology of Higher Education: From Activity to Personality. Moscow: Academy Publ. 125-126. [in Russian]

${ }^{29}$ Selevko G. K. (1998). Modern educational technologies: textbook. Manual. Moscow. 147-149. [in Ukrainian]

${ }^{30}$ Sliepkan Z. I. (2005). Scientific principles of pedagogical process in higher education: a textbook. Kyiv: High school Publ. 145-146. [in Russian] 
are chosen by the teacher on the basis of their knowledge of the conditions of occurrence of different types of problem situations. A form of implementation of this or that method is such didactic techniques as the formulation of a problem question, task, problem task, demonstration of experience.

The first way is to involve the students in the theoretical explanation of the phenomena, objects, external discrepancy between them. This leads to search activities and to the active acquisition of new knowledge.

The second way is to use learning and life situations that arise when students perform practical tasks, as a result of observations of nature, etc. Problematic situations in this case arise when students try to independently achieve their practical goals . Usually, students formulate the problem themselves at the end of the situation analysis.

The third way is to set educational problem tasks to explain the phenomena or to find ways of their practical application. An example would be any student research work at a study site, laboratory or office, as well as in a lesson.

The fourth way is to involve the students in the analysis of the facts and phenomena of reality that give rise to the contradictions between the ideas of life and the search concepts of these facts.

Fifth way - to make assumptions (hypotheses), formulate the results and test them.

The sixth way is to involve students in comparing, contrasting and contrasting the facts, phenomena, rules, actions that result in a problematic situation.

The seventh way is to involve students in the pre-summarization of new facts. The students are tasked with looking at some facts, phenomena that exist in the new material for them, comparing them with the known ones and making an independent generalization. In this case, as a rule, there is a problematic situation, as the comparison reveals the special qualities of new facts, their explanations are unclear.

Eighth way - students are introduced to facts that are incomprehensible and that have led the history of science to the scientific problem. Usually, these facts and phenomena seem to deny those concepts and ideas that students have formed, which are explained by the lack of their previous knowledge. 
The ninth way is to organize cross-curricular links. Often the material of the subject being studied does not provide a problem situation (when developing skills or repeating previous material, etc.). In this case, the facts and data of the sciences (subjects) that are relevant to the material being studied are used.

The tenth way is to vary the task, reformulate the question.

The problematic task should correspond to the level of development of the mental abilities of the listener, to proceed from the logic of the educational material, and the main thing - to be perceived by the listener as a natural difficulty, the overcoming of which is necessary. To raise the level of mental activity of the listener, it is necessary to gradually complicate cognitive tasks and their degree of independence in the solution.

In problem-based learning, it is necessary to create the most favorable conditions for the speech self-realization of the students through the introduction into practice of creative exercises, research tasks, problematic issues, etc. The primary task at the same time is the awakening of cognitive activity ${ }^{31}$. Cognitive activity at the level of the structural unit of personality orientation indicates that the listener not only willingly assimilated one or another information, but is distinguished by a strong need for quality cognitive activity, strong and persistent motives for this activity. Techniques that put the listener in an active position in the classroom include a number of learning situations: first of all, situations in which the listener must defend his or her opinion; situations that prompt students to ask a teacher or classmate; reviewing the responses, creative work of other students in the classroom and after-school activities; performing tasks designed to use additional literature; free choice of tasks, mainly of a search character; creating a situation of exchange of educational information among students; self-examination, analysis of own cognitive works. The indicator of the formed cognitive activity of the listeners can be primarily their actions. In particular, if the listener asks a question to the teacher; seeks, at its own request, to participate in educational activities, to discuss issues discussed at the lesson; complements the answers of other listeners, wishes to express his/her views; seeks to

${ }^{31}$ Fitsula M. M. (2006). Pedagogy of the Higher School: Educ. Tutorial. Kyiv. Academ. Edit., 312-313. [in Russian] 
share new information with others, complete the exercise started, in this case we can talk about his advanced cognitive activity.

\section{Use of the mechanism of defining the educational task in the process of solving problem situations}

We call problematic any situation, practical or theoretical, in which there is no obvious decision appropriate to circumstances and that is why it requires stopping and thinking. Depending on how the situation is perceived by the subject, he or she does or does not actually perform setting of the problem. We can assume that the transition from a problem situation to a task is caused by a special manifestation of the subject's activity - over situational activity, which characterizes the tendency of the subject to act above the threshold of external or internal situational necessity, go beyond the initial situation ${ }^{32}$

In its most general form, the task is a system, which mandatory components are:

1) The object of the problem, which is in the initial state;

2) A model of the desired state of the object of the problem, which is identified with the requirements of the problem ${ }^{33,34}$.

The problem G. O. Ball differs from a task (problematic) situation - a set of objects that allows a systematic representation in the form of a problem, but one that has not yet received such a representation. He also distinguishes it from the problem by its sign model, the partial case of which is a verbal description (formulation) ${ }^{35}$. [in Russian].

32 Okon V. (1988). Fundamentals of problem-based learning. Moscow.

${ }^{33}$ Ball G. O. (1990) The theory of learning tasks: Psychological-Pedagogical Aspect. Moscow: Pedagogics Publ. 165-167. [in Russian]

${ }^{34}$ Smulson M. L. (2019) Adult development in the modern transitive world Topical problems of psychology: Collection of scientific works of the G. S. Kostyuk Institute of Psychology of the National Academy of Pedagogical Sciences of Ukraine. 2019. Volume VIII: Psychological Theory and Technology of Learning. Issue 10. 328. [in Russian]

35 Smulson M. L.(2009). Intelekt i mentalni modeli svitu [Intellect and mental models of the world]. Naukovi doslidzhennia kohnityvnoi psykholohii - Scientific and cognitive psychology. Ostroh: Natsionalnoho universytetu "Ostroh" Publ., vol. 12, 38-49 [in Ukrainian] 
Petrovskyi V. A. distinguishes 2 levels of such activity: the phenomenon of "supersituation", that is, the redundancy of the subject's actions in relation to those requirements of the situation, which determine the criteria for the effectiveness of his behavior and are taken as primary data, as well as "counter-situation" when the subject acts contrary to the constraints that restrict his/her free development.

The main feature of the phenomena of super-situational activity is that "the subject, acting in the direction of realization of the initial requirements of the situation, goes beyond these requirements; the moments of activity appear at the same time as if they were separated in the facts of the subject's "going beyond the limits of the situation". Such "going beyond" the problem situation is observed, in our opinion, in the transition of the subject (group) to independent formulation of the problem and attempts to solve $\mathrm{it}^{36}$.

Therefore, the statement (vision) of the problem in a problem situation is one of the manifestations of supersituative activity, as well as active intelligence, or, according to D. B. Bogoyavlenskaya (1983), the intellectual activity of the individual. The tasking stage needs to be considered in all tasks, but especially in those that arise in practical work. Finding a future challenge - a problematic situation - is one of the most important properties of an intelligence practitioner - a professional. The task (problematic) situation is often not fully understood and exists to the extent that it, figuratively speaking, is the "present" person who invented $\mathrm{it}^{37}$.

The task differs from the task (problem) situation in that it is conscious by the subject, objectified and most often described verbally or in another sign (numeric, graphic form). The problem statement contains its analysis and understanding at a certain level, preliminary definition of the conception of the decision, strategy, plan of action. It, as a rule, involves taking into account the possible realistically available and present means of solving the problem (i.e. material,

36 Petrovskyi V. A. (1992) Psychology of over adaptive activity, Moscow. 152-154. [in Russian].

${ }^{37}$ Bogoyavlenskaya D. B. (1983). Intellectual activity as a problem of creativity. Rostov, Publ. Rostov Univers. 174. [in Russian] 
materialized and ideal objects that are not directly included in the conditions of the problem, but are involved in solving it) $)^{38,39}$.

An educational task is a task aimed at the achievement of learning goals, which is put forward by the teacher or the student sets himself.

Explicit include tasks that clearly state the condition and require explicit, that is, external, response. The implicit include tasks that do not have a clear condition and do not require a clear answer, and which are often used to stimulate the listener's internal dialogue, reflection of his or her activity, teacher's activity, or peculiarities of the functioning of the educational system.

The educational task is understood quite broadly, along with the thinking, there are also mnemonic, perceptual tasks, as well as tasks for understanding. Learning tasks are components of both educational and learning activities (in the latter it acts as a learning influence) $)^{40}$.

Definition of a learning task (learning influence) - can be considered as a special case of psychological mechanism of task definition, which takes place in any management system, in which a person is the object. Its specific feature is primarily due to the fact that the educational task occupies a different place in the structure of the students' activity than, for example, a production or scientific task in the activity of the respective specialists. Here, the solution does not meet the educational goal, but acts only as a means of achieving it, and to achieve even the closest goal (learning a certain mode of action, that is, a method of solving a certain class of problems) requires the solution of not one task, but a set of problems.

${ }^{38}$ Smulson M. L. \& oth. (2015). Intelektualnyi rozvytok doroslykh u virtualnomu osvitnomu prostori: monohrafiia [Adult intellectual development in the virtual educational space: a monograph]. Kyiv: Pedahohichna dumka. Publ. Retrieved from: http://lib.iitta.gov.ua/10064 [in Ukrainian]

${ }^{39}$ Furman A. V. (1987) Application of the problem situation // Sov. Pedagogy, № 3. 17-21. [in Russian]

40 Smulson M. L. (2016). Rozvytok intelektu ta subiektnosti doroslykh u virtualnomu prostori [The development of adult intelligence and subjectness in virtual space]. Tekhnolohii rozvytku intelektu - Technologies of Intellectual Development, vol. 2, 2(13). Retrieved from: http://psytir.org.ua/index.php/technology_intellect_ develop/issue/view/18 [in Ukrainian] 
The essence of this psychological mechanism can be formulated in the following way: any learning influence on the part of the teacher in the form of a task (the main learning influence), explicit or implicit, subjected to the students processing, resulting in a discrepancy between the task posed by the teacher, and in fact one solved by the listener $^{41}$.

This psychological mechanism of learning reflects primarily the features of internal determination: under the influence of various factors (both motivational and intellectual), the listener transforms the task from the outside (task situation) into a task in the psychological sense.

Thus, a definite task can be imagined as a projection to the task externally actualized goals of the subject-motives (it reflects both the personal meaning of the trainees, as well as certain situational factors), as well as intellectual property (abilities, habits and knowledge, the subjective world as a whole). Regarding learning tasks, the principle is as follows: the goals must be aligned with the learning goals when solving problems. In the process of defining a task, the listener firstly sets a specific goal (sometimes, even without being fully aware of it), and secondly, sets his own requirements for the process and the product of its solution.

The theoretical significance of the psychological mechanism of defining the educational task is, first of all, that it makes it possible to scientifically substantiate the following position: even in the conditions of rigidly determined training, the student acts not only as an object of management, but also as a subject of educational activity. After all, he/she determines the nature of the projection to the task externally, and thus actually solved the problem. The fundamental importance of this provision is that it demonstrates the scientific failure of a behaviorist approach to learning, which plays a decisive role in the system of rewards and punishments. While not denying the importance of rewards and punishments in the educational process, we also

${ }^{41}$ Smulson M. L. (2014). Psykholohichni mekhanizmy v kontseptsii navchannia Yu.I. Mashbytsia [Psychological Mechanisms in the Concept of Teaching YI Mashbits]. Tekhnolohii rozvytku intelektu - Intellectual Development Technologies, vol. 1, 6. Retrieved from: http://psytir.org.ua/index.php/technology_intellect_develop/ article/view/123 [in Ukrainian] 
emphasize the incorrectness of giving them a decisive role and essentially reducing the personality of the listener to the object of manipulation. Solving the external task, the listener remains essentially the subject of his/her activity, because he/she defines this task.

If the learner does not correlate his/her solution to the learning goals when solving a problem, his/her activity cannot be considered as an educational task, although he/she fulfills an important requirement when solving a learning problem: the student uses only available means of solving problems ${ }^{42,43}$.

It cannot be said that the didactic effect will always be zero. He may spontaneously memorize some of the techniques for solving a given task that are typical of a particular class, and after a while, when solving another task, the listener may recall that technique and generalize it. In doing so, he may even unknowingly relate the solution of the problem to such a learning purpose as mastering a particular way of solving the problem. However, it is of fundamental importance that the latter is accomplished in the solution of another problem, and here it has to be determined ${ }^{44,45}$.

In the light of this psychological mechanism, the definition of a learning task can be justified by the well-known proposition that the student begins to solve the learning problem only when he/she sees in it his/her personal meaning. At first glance, it may seem that solving a typical learning problem may not make personal sense. Undoubtedly,

42 Smulson M. L. (2016). Rozvytok intelektu ta subiektnosti doroslykh u virtualnomu prostori [The development of adult intelligence and subjectness in virtual space]. Tekhnolohii rozvytku intelektu - Technologies of Intellectual Development, vol. 2, 2(13). Retrieved from: http://psytir.org.ua/index.php/technology_intellect_ develop/issue/view/18 [in Ukrainian]

43 Smulson M. L. (2003). Psykholohiia rozvytku intelektu [Psychology of Development of Intellect]. Kyiv: Nora-Druk Publ. [in Ukrainian]

${ }^{44}$ Smulson M. L. \& oth. (2015). Intelektualnyi rozvytok doroslykh u virtualnomu osvitnomu prostori: monohrafiia [Adult intellectual development in the virtual educational space: a monograph]. Kyiv: Pedahohichna dumka. Publ. Retrieved from: http://lib.iitta.gov.ua/10064 [in Ukrainian]

${ }^{45}$ Smulson, M. L. \& oth. (2018). Rozvytok subiektnoi aktyvnosti doroslykh $u$ virtualnomu prostori [The development of adult subjective activity in virtual space]. Kyiv: H. S. Kostiuk Institute of Psychology of the National Academy of Pedagogical Sciences of Ukraine. Retrieved from http://lib.iitta.gov.ua/712119/1/The development of adult subjective activity in virtual space.pdf [in Ukrainian] 
such a task does not make sense to the listener if it limits the listener's purpose to find what he/she is looking for. But, as stated above, in the process of defining a given task from the outside, the student correlates it with the current educational goals for him/her. A learning task acquires a personal meaning for the listener because he / she is aware that the solution of this task ensures the achievement of a certain educational goal or at least promotes it ${ }^{46}$.

Thus, the student's learning activities are not limited in any way to the solution of the tasks set by the teacher. The latter act as specific task situations for him/her and the listener greatly expands the range of these situations by setting and solving various learning tasks. Without any exaggeration, it can be argued that a great role in the activity of the listener is the independent formulation and solution of various learning tasks. In other words, it is the activity of the listener in the world of learning tasks ${ }^{47}$.

The mechanism of defining the educational task reveals new limits of the study of the psychological development of the listener, the source of his/her self-development. One of the most important components of the personal development of listeners is the development of content, first of all, personal content. These changes reflect the development of the intentional side of activity, which in turn characterizes the orientation of the individual, and the content system, as emphasized by D. O. Leontiev, ensures correspondence of the activity to the intentional sphere of personality, coordinating the tasks of the activity with motives, needs, values, and attitudes of the listerner ${ }^{48}$.

We believe that students 'determination of learning tasks, manifested in the extension of the cognitive field given by the teacher, which defines the system of tasks, is one of the most important sources

46 Mashbyts, Yu. I. (2019). Psykholohichni mekhanizmy i tekhnolohiia navchannia [Psychological mechanisms and technology of teaching]. Kyiv: Interservis Publ. [in Ukrainian]

${ }^{47}$ Rybalka V. V. (1996) Psychology of creative personality development: a textbook. Kyiv: MOD Publ. 155-157. [in Russian]

${ }^{48}$ Leontiev, D. A. (2013). Lichnostnoe izmerenie chelovecheskogo razvitiya [The personal dimension of human development]. Voprosy psihologii-Psychological issues, 3, 67-80 [in Russian] 
of students' self-development. Constructing the learner a task space characterizes not only the learning activity but also his/her personality, above all the cognitive, motivational and will spheres.

This leads to an important conclusion: the teacher should stimulate the students not only to such a definition of tasks, which is based on the variation of certain subject content, but also to the formulation and solution of tasks to reflect one's activity ${ }^{49}$. The most appropriate form of learning is the intellectual training of listeners, which promotes that the students' awareness of their mental structures acts as a direct product of their actions.

Therefore, in our opinion, one of the areas of the restructuring of the education system is the widespread use of problem-based learning, which should take a prominent place in daily educational work with students.

\section{CONCLUSIONS}

To sum up, PBL has the potential to improve students' higherorder thinking skills, comprehension and application of knowledge, learning attitudes and motivation. This learning experience helps students to develop understandings of themselves and their contexts, and the ways and situations in which they learn effectively.

The peculiarity of organizing the problem-based learning process is the problem situation - the main means of activating students' mental activity.

Purposeful use by the teacher of problem situations that arise in addition to his/her desire (objectively) and situations intentionally created by them, are a system whose skillful application is the main feature of problem-based learning and its difference from traditional one.

In problem-based learning, it is necessary to create the most favorable conditions for the speech self-realization of the students through the introduction into practice of creative exercises, research tasks, problematic issues, etc. The primary task at the same time is the awakening of cognitive activity.

49 Mashbyts, Yu. I. (1997). The basis of new information technologies of studying. Kiev: H. S. Kostiuk Institute of Psychology of the National Academy of Pedagogical Sciences of Ukraine, 46-49. [in Ukrainian] 
The transition from a problem situation to a task is caused by a special manifestation of the subject's activity - over situational activity, which characterizes the tendency of the subject to act above the threshold of external or internal situational necessity.

An educational task is a task aimed at the achievement of learning goals, which is put forward by the teacher or the student sets himself. The educational task is understood quite broadly, along with the thinking, there are also mnemonic, perceptual tasks, as well as tasks for understanding. Learning tasks are components of both educational and learning activities

Any learning influence on the part of the teacher in the form of a task (the main learning influence), explicit or implicit, subjected to the students processing, resulting in a discrepancy between the task posed by the teacher, and in fact one solved by the listener.

The mechanism of defining the educational task reveals new limits of the study of the psychological development of the listener, the source of his/her self-development.

Students 'determination of learning tasks, manifested in the extension of the cognitive field given by the teacher, which defines the system of tasks, is one of the most important sources of students' selfdevelopment.

the teacher should stimulate the students not only to such a definition of tasks, which is based on the variation of certain subject content, but also to the formulation and solution of tasks to reflect one's activity.

\section{SUMMARY}

The article is devoted to the peculiarities of using of problembased learning in the training system.

A detailed analysis of the organization conditions of the educational process has been carried out. The requirements have been revealed which allow positive results' achievement when performing problematic tasks. Characteristics of problem-based learning, main principles and components of problem situations have been formulated. 
A detailed psychological analysis of the mechanisms of problematic situations solving, peculiarities of organization of problem learning process has been carried out.

Use of the mechanism of defining the educational task in the process of solving problem situations has been worked out in detail. It is proved that students' awareness of their mental structures acts as a direct product of their subsequent actions.

\section{REFERENCES}

1. Antonenko T. L. (2019). Psychological bases of formation of value-semantic sphere of personality of the future specialist. Dissertation author's abstract on obtaining scientific degree of doctor of psychological sciences. Kyiv. 38-39 [in Ukrainian].

2. Ball G. O. (1990). The theory of learning tasks: PsychologicalPedagogical Aspect. Moscow. Pedagogics Publ. 165-167 [in Russian].

3. Baranovska L. V. (2015). Pedagogy and Psychology of Higher School: Educ. Manual. Kyiv. NAS Publ. 223-225 [in Ukrainian].

4. Bogoyavlenskaya D. B. (1983). Intellectual activity as a problem of creativity. Rostov, Publ. Rostov Univers. 174. [in Russian].

5. Bruner J. (1977). Psychology of knowledge. Beyond direct information. trans. from English. Moscow. Progress Publ. 223-224 [in Ukrainian].

6. Vygotsky L. S. (1982). The problem of will and its development in a child's age. Vol. 3, 452-455. [in Ukrainian].

7. Grishko-Dunaevskaya V. A. (2016). Features of subjectsubject interaction in the process of learning a foreign language in higher military educational institutions. Khmelnytskyi. : dissertation author's abstract on obtaining a scientific degree of candidate of psychological sciences, 6. [in Ukrainian].

8. Denisyuk A. S. (1976). Searching in lessons. Pr. School. № 4., 31-37. [in Ukrainian].

9. Duch BJ, Groh SE \& Allen DE (2001). The Power of ProblemBased Learning, New York Edition. 112-113.

10. Zhitko T. (2002). Learning Methods - Precondition for Intellectual Development of Personality. Native School. 2002. № 6, 72-77 [in Ukrainian]. 
11. Ivanova L. (1988). Increasing of students' cognitive activity. Public education, 4. 42-47 [in Russian].

12. Ilnitskaya I. Ya. (1985) Problem situations and ways to create them in a lesson. Moscow. Knowledge Publ. 57-59 [in Ukrainian].

13. Kostiuk, G. S. (1969). Princip razvitiya $v$ psihologii [The principle of uncertainty in the psychology of choice and risk. Methodological and theoretical problems of psychology]. Moscow: Nauka Publ. [in Russian].

14. Kudryavtsev T. V. (1987). Issues of psychology and didactics of problem learning. Problem education. Moscow. Enlightenment Publ. 145-148 [in Russian].

15. Leontiev, D. A. (2013). Lichnostnoe izmerenie chelovecheskogo razvitiya [The personal dimension of human development]. Voprosy psihologii - Psychological issues, 3, 67-80 [in Russian].

16. Lerner I. Ya. (1974). Problem-based learning. Moscow. 128-129 [in Russian].

17. Matyushkin A. M (2003). Thinking, training, creativity. Moscow: Moscow Ed. Psychol. Soc. Inst; Voronezh: MODEK Publ. 615-616 [in Russian].

18. Matyushkin A. M. (1972). Problem situations in thinking and learning. Moscow. Pedagogy Publ. 78-80 [in Russian].

19. Makhmutov M. I. (1975). Problem-Based learning. Moscow [in Russian].

20. Mashbyts, Yu. I. (2019). Psykholohichni mekhanizmy $i$ tekhnolohiia navchannia [Psychological mechanisms and technology of teaching]. Kyiv: Interservis Publ. [in Ukrainian].

21. Mashbyts, Yu. I. (1997). The basis of new information technologies of studying. Kiev: H. S. Kostiuk Institute of Psychology of the National Academy of Pedagogical Sciences of Ukraine, 46-49. [in Ukrainian].

22. Molyako V. A. (2003). Schoolchildren psychology of creative problems solving. Kyiv. Glad Publ. 78-79 [in Ukrainian].

23. Okon V. (1988). Fundamentals of problem-based learning. Moscow [in Russian].

24. Petrovskyi V. A. (1992). Psychology of over adaptive activity. Moscow. 152-154 [in Russian].

25. Rybalka V. V. (1996). Psychology of creative personality development: a textbook. Kyiv: MOD Publ. 155-157 [in Russian]. 
26. Romanyuk I. M., Bogaychuk V. J. (2011). Problem studyingone of the effective methods of searching-cognitive activity of cadets (listeners), Bulletin of the National University of Defense of Ukraine, 6 (25). 47-55 [in Ukrainian].

27. Selevko G. K. (1998). Modern educational technologies: textbook. Manual. Moscow. 147-149 [in Ukrainian].

28. Sliepkan Z. I. (2005). Scientific principles of pedagogical process in higher education: a textbook. Kyiv: High school Publ. 145-146 [in Russian].

29. Smirnov S. D. (2003). Pedagogy and Psychology of Higher Education: From Activity to Personality. Moscow: Academy Publ. 125-126 [in Russian].

30. Smulson M. L. (2019) Adult development in the modern transitive world Topical problems of psychology: Collection of scientific works of the G. S. Kostyuk Institute of Psychology of the National Academy of Pedagogical Sciences of Ukraine. 2019. Volume VIII: Psychological Theory and Technology of Learning. Issue 10. 328. [in Russian].

31. Smulson M. L. (2016). Rozvytok intelektu ta subiektnosti doroslykh $u$ virtualnomu prostori [The development of adult intelligence and subjectness in virtual space]. Tekhnolohii rozvytku intelektu - Technologies of Intellectual Development, vol. 2, 2(13). Retrieved from: http://psytir.org.ua/index.php/technology_intellect_ develop/issue/view/18 [in Ukrainian].

32. Smulson M. L. \& oth. (2015). Intelektualnyi rozvytok doroslykh u virtualnomu osvitnomu prostori: monohrafiia [Adult intellectual development in the virtual educational space: a monograph]. Kyiv: Pedahohichna dumka. Publ. Retrieved from: http://lib.iitta.gov.ua/10064 [in Ukrainian].

33. Smulson, M. L. \& oth. (2018). Rozvytok subiektnoi aktyvnosti doroslykh $u$ virtualnomu prostori [The development of adult subjective activity in virtual space]. Kyiv: H. S. Kostiuk Institute of Psychology of the National Academy of Pedagogical Sciences of Ukraine. Retrieved from http://lib.iitta.gov.ua/712119/1/The development of adult subjective activity in virtual space.pdf [in Ukrainian].

34. Smulson M. L. (2003). Psykholohiia rozvytku intelektu [Psychology of Development of Intellect]. Kyiv: Nora-Druk Publ. [in Ukrainian]. 
35. Smulson M. L. (2014). Psykholohichni mekhanizmy v kontseptsii navchannia Yu. I. Mashbytsia [Psychological Mechanisms in the Concept of Teaching YI Mashbits]. Tekhnolohii rozvytku intelektu - Intellectual Development Technologies, vol. 1, 6. Retrieved from: http://psytir.org.ua/index.php/technology_intellect_develop/ article/view/123 [in Ukrainian].

36. Smulson M. L. (2009). Intelekt i mentalni modeli svitu [Intellect and mental models of the world]. Naukovi doslidzhennia kohnityvnoi psykholohii - Scientific and cognitive psychology. Ostroh: Natsionalnoho universytetu "Ostroh" Publ., vol. 12, 38-49 [in Ukrainian].

37. Fitsula M. M. (2006). Pedagogy of the Higher School: Educ. Tutorial / M. M. Fitsula. Kyiv: Academ. Edit. 312-313 [in Russian].

38. Furman A. V. (1987). Application of the problem situation. Sov. Pedagogy, 3. 17-21 [in Russian].

39. Shynkaruk O. M., Didenko O. V. (2017). Problem-based learning of border guards: theory, methodology, practice: a manual. Khmelnitsky: edition of the NASBGS, 67-68. [in Ukrainian].

40. URL: https://citl.illinois.edu/citl-101/teaching-learning/ resources/teaching-strategies/problem-based-learning-(pbl). Problembased learning teaching-strategies.

41. URL: https://www.maastrichtuniversity.nl/education/whyum/problem-based-learning. Problem-based learning.

42. URL: https://www.studygs.net/pbl.htm. Problem-based learning $(\mathrm{PBL})$ is an exciting alternative to traditional classroom learning.

43. URL: https://www.learning-theories.com/problem-basedlearning-pbl.html. Problem-based learning learning-theories.

44. URL: https://www.studyinternational.com/news/problembased-learning-in-the-classroom-yay-or-nay. Problem-based-learningin-the-classroom-yay-or-nay.

45. URL: https://www.wits.ac.za/therapeuticsciences/occupational-therapy/about-us/problem-based-learning. Occupational-therapy.

46. URL: https://www.forbes.com/sites/michaeltnietzel/2019/10/ 29/new-strong-evidence-for-problem-based-learning/\#2f9c67e86ab8. New-strong-evidence-for-problem-based-learning. 
47. URL: https://www.sciencedirect.com/science/article/pii/S24 52301116300062. Problem-Based Learning: An Overview of its Process and Impact on Learning.

48. URL: https://doi.org/10.1016/j.hpe.2016.01.004. The theory of problem-based-learning.

\section{Information about the author:} Artem Chornyi

Chef of Course of Engineering-Technical Faculty, National Academy of the State Border Guard Service of Ukraine named after Bohdan Khmelnytskyi 46, Shevchenko str., Khmelnytskyi, 29003, Ukraine ORCID ID: orcid.org/0000-0002-5541-1910 E-mail: chorniart@gmail.com 


\section{FORMATION OF PROFESSIONAL SELF-ASSESSMENT OF BORDER GUARD OFFICERS-INTENDING MANAGERS}

\section{Valentyn Demskyi}

\section{INTRODUCTION}

The main purpose of any mental phenomenon investigation is the use of the obtained knowledge in practice. Therefore, along with the theoretical consideration of reflexive processes, it is important to analyze certain properties in the practical activities of a border guard officer. The choice of management activities aimed at the analysis of the mechanisms of reflexive regulation is not accidental. Researchers have repeatedly provided a rationale for the importance of exploring reflective processes in management-related activities. Reflection is seen as a process of awareness of activity in works of philosophy and psychology, it is defined as a common component of its various types, including in the field of management. It is in this area that reflection is most important for border guard officers, because qualification of an officer presupposes managerial and organizational activities in the process of units' management, as well as the bodies of the State Border Guard Service of Ukraine and its other socio-economic systems.

Specifics of management of socio-economic systems, according to V. Polyakov ${ }^{1}$, presupposes the following basic aspects of self-esteem:

- identifying features of the awareness process of one's individual activity in making and implementing managerial decisions;

- awareness of the cooperative activities of participants in collective decision-making procedures to coordinate it;

- formation of the subject of management in the process of education.

The purpose of the article is to analyze the scientific papers presenting results of research on the concept of "self-esteem of a border guard officer" in the system of his professional activity and to create a program and model of its formation.

${ }^{1}$ Morozov, I. V., Zalozh, V. V., Shyrobokov, S. M. (2003). Naukovi osnovy upravlinnia, Chastyna I. [Scientific Foundations of Management, Part I]. Khmelnytskyi.: Vydavnytstvo Natsionalnoi akademii DPSU, 150 p. [in Ukrainian]. 


\section{Professional self-assessment of border guard officers and managing activity}

Transition from an extensive type of management to an intense one is impossible in modern society without increasing the value of reflective processes. It should be noted that the extensive type of management has given rise to a simplified view of the potential for influencing the entity through a combination of external incentives, in particular when the means and methods of management are given from the outside sources. An intensive type of management implies an awareness of the subject of management of its role, resulting in the synthesis of new principles and mechanisms of management.

In order to determine the role of self-assessment in the management activities of border guard officers and to identify the mechanisms of functioning of this characteristic property in practical activities, it is necessary to reveal the content of management activities.

It is noteworthy that management is a culture, a system of values, as well as a means for society development. Functioning of a developed society, solving important tasks is impossible without organizational and managerial institutions. Management is characteristic of any social phenomenon that is associated with joint activities to achieve common goals. Nowadays, with the development and complexity of society, it is easier to set up an enterprise than to manage it effectively. This pattern indicates the increasing role of management.

Managing an organization includes the performance of administrative and managerial functions ${ }^{2}$, aimed at the recruitment and placement of personnel, their management, as well as educating people initiative and independence, control of their work, the use of economic ways to influence the activities of the team. Management in a broad sense is a system of measures aimed at defining the goals of a particular production line, as well as the development and

${ }^{2}$ Potapchuk, Y. M. (2004). Teoriia ta praktyka zberezhennia psykhichnoho zdorovia viiskovosluzhbovtsiv: Monohrafiia [Theory and practice of maintaining the mental health of servicemen: A monograph]. Khmelnytskyi: Vydavnytstvo Natsionalnoi akademii DPSU, 323 p. [in Ukrainian]. 
implementation of actions aimed at organizing a team to achieve these goals, for systematic coherence of work, objects of work, means and all participants of the production organization, ensuring normal working conditions and improving the cultural and technical level of personnel and their socio-cultural service ${ }^{3}$. A rather broad definition of management is given to demonstrate its multidimensionality. It should be noted that management requires more complex regulation, involvement of a whole complex of processes and properties. It mainly refers to integral psychic processes, such as reflexivity. Due to their complexity and indirectness to other mental manifestations, a systematic, multidimensional approach to consideration of management activity and the importance of the reflexive processes of its regulation can be used.

To confirm the validity of the choice of research topic, to identify the value of reflective processes, according to V.G. Polyakov, considering management activities in three aspects: 1) the functions performed by the head, i.e. the content of the activity; 2) determining the professionally important qualities of a manager; 3) through characterization of principles and methods of activity training.

Such processes ${ }^{4}$ as planning (determining the ways, means and pace of achievement of intermediate and final goals), control (determining the degree of achievement of the ultimate goal or deviation from it), correction (identifying and using new or additional ways and means of achieving the final goals) are considered the main functions of management process. The object of management is the organization, that is, the system. Its components are people who hold professional positions in the organizational structure and determine the functional relationships between its components.

Management is aimed at optimizing people's professional activity through economic, administrative, psychological and pedagogical

${ }^{3}$ Morozov, I. V., Zalozh, V. V., Shyrobokov, S. M. (2003). Naukovi osnovy upravlinnia, Chastyna I. [Scientific Foundations of Management, Part I]. Khmelnytskyi.: Vydavnytstvo Natsionalnoi akademii DPSU, 150 p. [in Ukrainian].

4 Potapchuk, Y. M. (2004). Teoriia ta praktyka zberezhennia psykhichnoho zdorovia viiskovosluzhbovtsiv: Monohrafiia [Theory and practice of maintaining the mental health of servicemen: A monograph]. Khmelnytskyi: Vydavnytstvo Natsionalnoi akademii DPSU, 323 p. [in Ukrainian]. 
influences, taking into account the needs, values, and attitudes of an individual or a group. In technological terms, the basis of management processes is the acceptance and processing of information, decisionmaking in times of scarcity of time and information ${ }^{5}$.

If you consider the activities of management from the point of view of the manager, the following stages can be distinguished: diagnostics and prediction of the state of the managed system; forming a program of activities of subordinates aimed at changing the state of the object in a given direction; organization and execution of decisions. It should be noted that:

1) Programming involves predicting progress, performance, modeling and communicating the program to the object of management. In essence, the planning function covers three areas, namely the state of affairs (assessment of opportunities, taking into account external and internal factors), the goals that should be achieved, and the means required for their implementation. It is important to point to the fact that the reflexive mechanisms of planning management activities are not a single action, but an ongoing process. What really works is not the kind of management that makes decisions to solve certain problems, but the one that anticipates possible solutions and such planning of work in the organization to eliminate the need for problems solution. The skills of such advanced management, of course, require a high level of development of self-esteem abilities.

2) The function of the organization is to create a specific structure to perform the planned activities. Selection of people, delegation of tasks, powers and responsibilities for success are the main tasks of a manager in the organization of work. It also requires the ability to understand the situation in detail, the ability to freely mentally operate different parameters of the situation, to correlate its components and factors, to predict the course of future activity. Each manager should not only organize the work of his unit, but also rationally allocate his/ her own time. As it is revealed, the manager works much more effectively if he makes the program consciously, that is, if he has a tendency to self-assessment.

${ }^{5}$ Smolskij, S. M., Filippov, L. I. (2005). Tri shaga k professii: nauka, disertaciya, pedagogika [Three steps to the profession: science, dissertation, pedagogy]. Odessa: «Neptun-Tehnologiya», 125 p. [in Russian]. 
3) the function of motivation of employees provides that performers were interested in performance of work according to the rights and duties delegated to them. The motivation is paid more attention with the development of society. Nowadays, humanity considers not only physical and material (for example, such as monetary compensation) methods of increasing interest in work, but understands motivation as a process of creating an internal motivation for activity through taking into account the many needs of the employee. In this regard, the manager should study his subordinates, which requires skills of perception of the human condition, personal characteristics, motivational orientation, interests, interpretation of behavior in different situations. For an adequate understanding of the other person, the manager needs both the diagnostic skills, and reflective abilities, which are a property of the personality. It is known that a person does most willingly what he decides to do on his own. The manager has to set a task in such a way that the subordinate will consider the goal as his own and acts with initiative and creativity. The professionally important quality of the manager is the ability to accept the point of view of another person. When choosing measures to influence the misconduct and violations of subordinates, an experienced manager should always try to understand why the subordinate acted in this way, only then will he make the right decision.

It should be noted that the success of any team depends on the authority of the manager. The main feature of any authoritative manager is the ability to control the actions of others through the influence of his own personality, and this is associated with selfassessment, as well as with the awareness of capabilities and competence, understanding others expectancies, the ability of devotedness.

4) Control as a feedback function is closely related to planning. There are three aspects of management control:

- setting standards, that is, pinpointing the goals to be achieved by a specific deadline;

- identification of achievements and comparison with expected results;

- necessary actions for correction of the revealed deviations.

The imaginary actions on control, correction, and anticipation of results taken out on accurately realized analyzed levels increase 
efficiency of administrative activity, and as a result, are formed on the basis of self-assessment.

So, each of the functions of management is associated with the definition, processing, exchange of information and decision-making. The border guard officer needs to analyze many options for potential actions to find the most optimal one in a given situation. As a rule, you need to model the activity, having several alternative solutions. When making a decision, the border guard officer must choose what and how to plan, what means and ways to carry out activities, how to motivate subordinates and how to control the correction. All these actions are impossible without reflexive abilities. Given the importance of management functions, it can be argued that reflexivity, as a factor of their successful implementation, can affect both the procedural aspect of the activity and the final result.

An interesting description of the management activities of Herman A. Schreder ${ }^{6}$. The scientist analyzes what practical actions need to be applied in solving management problems. The first place, in his opinion, is the need for a clear recognition of the situation, the definition of deviations when comparing the planned and actual state of the managed system. This task is not easy, some managers can find such problems where they do not exist, or vice versa, managers cannot notice important features of the problem. Having noticed deviations, the manager should try to find the possible reasons of a deviation, and analyse the errors. The most important prerequisite for determining the causes of deviation is to find as many of them as possible. The manager who finds 15 causes of error when solving a problem is more suitable for management activities than one who names only two reasons. The ability to find more possible causes of deviation not only increases the probability of correct solution of the problem but also creates a prerequisite for more flexible solutions to problems that may arise in the future. However, only the rich imagination is not enough when looking for possible errors. It is necessary for manager to be able to conduct a detailed analysis of versions to find the truth. The manager must then identify possible measures and ways of behaving in

${ }^{6}$ Manhutov, Y. S., Umanskyi, L. Y. (1975). Orhanizator i orhanizatorskaia deiatelnost [Organizer and organizing activity]. Lviv, 310 p. [in Russian]. 
the situation. To do this, he needs to make an analysis of the measures provided for by the instructions and recommendations, assess his own experience, consider the measures already taken. Then he chooses ways to behave. However, most often under different circumstances, there are no necessary instructions for behavior. The choice of new methods makes you think about what the consequences may be after the application of certain measures. This means that the manager must consider the various consequences and know the advantages and disadvantages of certain activities. The last action-the test of success-is needed to find out whether the new West has contributed to reducing the deviation of actual behavior from the normative, whether additional measures are needed.

The logical continuation of the rationale for the importance of reflective processes in management activities on the basis of consideration of its stages and functions can be considered an approach in which the analysis of errors that are most common in management activities. Thus it is possible to reveal the most important key moments of activity connected with the necessity of the reflexive decision of this or that situation. In order for the border guard officer to organize his personal according to their abilities, and be fair in the performance of his daily tasks, it is necessary to constantly assess the staff's behavior. Experts believe that it is impossible to evaluate other people accurately and completely objectively. The manager can only learn to reduce the number of errors that necessarily occur when making estimates. Many experiments ${ }^{7}$ indicate the negative influence of subjective confidence in making an assessment (which, incidentally, is a sign of impulsion in decision-making). Those managers who felt the most confident in making the assessment were often wrong, and the estimates of those managers who felt insecure were significantly more accurate. Uncertain people when observing - more analytical, thoughtful, they consider opposite points of view, analyze different details, attract more information and are ready at any time to doubt their assessment, correct it. Thus, errors in the evaluation of subordinates often arise due to excessive confidence in their rightness, which has developed under

${ }^{7}$ Manhutov, Y. S., Umanskyi, L. Y. (1975). Orhanizator i orhanizatorskaia deiatelnost [Organizer and organizing activity]. Lviv, 310 p. [in Russian]. 
the influence of the initial installation. Besides, in the formation of a correct assessment of the subordinate, the ability to give clear speech formulations to his thoughts plays an important role, since impulsive, inaccurate and vague characteristics cause many misunderstandings when making an assessment.

It should be noted that other errors are also caused by insufficient reflection over the situation, they happen in the process of influencing the subordinate officer. Often, instead of making sense of the situation, the manager uses a stereotypical reaction or stereotypical expressions: "You cannot be charged anything", "You are always late", "This is very similar to you", etc. ${ }^{8}$. The decision can be made too hastily, under the influence of strong emotions. Some situations cause unpleasant associations. In such cases, officers react without understanding, without delving into the details, taking a superficial decision. Lack of selfcontrol, unformed habits of reflection to the situation, could significantly reduce the effectiveness of management. The inability to " broadly " look at the situation, the lack of alternatives in decision-making can make some problems. For example, why does a subordinate work slowly: because he cannot, does not want to work faster, just tired, or is burdened by a state of uncertainty due to instability in the unit? Besides, choosing a way of influence on the subordinate, the border guard officer not always considers the long-term consequences of the behavior. This is especially true of concomitant negative phenomena. The lack of consideration of different points of view, in particular, his own and subordinates can be added.

The next constituent analysis of reflective processes significance in management is a consideration of their role in allocation of professional-important qualities of an officer-borderguard.

It is important to consider that in the structure of a manager the reflection is not simply important, but also acts as an integrator of other properties. Reflexive processes are so actively involved in all managerial functions, that reflection is a part of the vast majority of professionally important qualities.

8 Safin, O. D. (1997). Psykholohiia upravlinskoi diialnosti komandyra: navchalnyi posibnyk [Psychology of commander's management activity: a textbook]. Khmelnytskyi: Vydavnytstvo Akademii PVU, 149 p. [in Ukrainian]. 
In this regard, there are interesting results of experimental researches, indicated by I. Mangutov and L. Uman ${ }^{9}$. We are talking about the specific properties of a skilled organizer. Of the entire number of experiment participants (potential organizers), these properties were found in almost $90 \%$ of cases. The authors describe three qualities.

The first one is "psychological selectivity", which is manifested through several life and experimental indicators:

- Frequent facts of fast, simultaneous, "collapsed", sometimes non-verbal and unconscious reflection of psychological features and states of other people;

- Empathy of the person that feel other people, i.e. emotional synchronicity;

- High sensitivity and susceptibility in the description and demonstration of psychological objects from stories, books, paintings;

- Possibility to characterize psychological peculiarities of people quickly and adequately;

- Preferable choice of psychological objects from many others that simultaneously operate on a person;

- Selective-psychological memory and observation;

- Tendency to psychological analysis, explaining the behavior and actions of other people and their own;

- Deep conviction in the forces and capabilities of the group;

- The ability to mentally visualize themselves in the psychological situation of another person, to think as this person, asking yourself the question: "How would I have done in her/his place?"

Psychological selectivity is the ability to quickly and deeply delve into the psychology of another person, to "understand" it, skillfully changing the tone and form of communication, means and methods of influence. The leader, possessing a psychological selectivity, easily determines what the employee is capable of, catches changes in the team, skillfully groups people. One of the indicators of this property is empathy, ability to stand in the place of another person, empathy.

${ }^{9}$ Morozov, I. V., Zalozh, V. V., Shyrobokov, S. M. (2003). Naukovi osnovy upravlinnia, Chastyna I. [Scientific Foundations of Management, Part I]. Khmelnytskyi.: Vydavnytstvo Natsionalnoi akademii DPSU, 150 p. [in Ukrainian]. 
Interest to people, craving to communicate with them, to remember their deeds are also associated with psychological selectivity. It should be noted that this property, which is especially important for the theoretical generalization of the analyzed literary material, determines the ability to give a characteristic to a person, his psychological portrait, determine the tendency to the psychological analysis, explaining the behavior and deeds of other people and their own.

The second specific characteristic of a skilled organizer, for I. Mangutov and L. Uman, is practically-psychological mind, which is manifested in the following characteristics:

- Distribution of responsibilities of collective activities, taking into account individual characteristics of people;

- Rapid orientation in situations requiring the practical application of human knowledge;

- Quick adaptation of a psychological state, mood of people to certain conditions of activity;

- Ability to induce stimulating motives of activity;

- Taking into account the influence possibilities of personal sympathies and antipathies, psychological differences of people when uniting them to perform collective activities;

- High level of learning in the formation of organizational skills;

- The tendency to solve practical issues through the prism of available human capabilities, a kind of imaginary, "fitting", "weighing" in accordance with the tasks of practice, the number and quality of possible performers.

Practically-psychological mind is the quality that provides the ability to find the best practical application for each person depending on its individual psychological peculiarities. Rapid orientation in situations requiring practical application of people psychology knowledge, ability to solve practical issues taking into account the possibilities of the staff.

The third quality of an organizer is a psychological tact that characterizes the style of communication of the leader with subordinates and colleagues. This is the degree of approach to people in establishing relationships and interactions with them, which is expressed in the ability to find a tone and a form of communication very quickly, depending on the psychological state and the individual characteristics of other people. 
Obviously, this property is also connected with the ability to penetrate into personal inner world, the ability to understand his/her feelings and reactions to the behavior of other people. Three considered properties is a kind of unity. This group specific quality of the authors is called "Organizing flair".

The art of managing largely depends on the ability of a person to feel how it is evaluated by subordinates, and to act as to influence them. Management consciousness of the leader is an internal model of external managerial relationships. The principle of feedback involves the perception of itself only in relations with others, that is, as the other - the reflective "I". The leader self-consciousness related to "I" actual ("What I did and how it influenced the others") and "I" reflective ("How employees and supervisors assess my actions").

If "I" actual expressed the opinion of the leader according to the other, then the "I" reflective - look at myself from the side. If the head is a man, then for him more value may have "I" actual. If the head is a woman, then for her more value may have "I" reflecrive, that is, the assessment of others not only on how it works, but also how it looks. The reflective "I" of the self awareness leader is his "second voice". "I" reflective can correspond to the idea of the head about himself or vice versa, contradict, especially after criticism in his address. This criticism is a threat to the actual "I". If the Supervisor Reboron doubts and recognizes the false manifestation of the actual "I", then this selfregulation of his self awareness is carried out as the restoration of managerial equilibrium with the reflective "I". Managing your behaviour correlates with the estimated expectations of those who may express criticisms. In the minds of the head formed model of possible deviations, which must be avoided in order to maintain the necessary level of self-respect. He/she can lose in his own notion of the past events (focusing on his experience - retrospective reflection) and the present (focusing on possible critical estimates situational reflection) to predict managerial impact effects (perspective reflection). Self-correction of his/her internal relations between the actual "I" and the reflection happens as a self-control of behavior on possible deviations to succeed in managerial activities. 
The organizing abilities of the intuitive plan in literature ${ }^{10}$ include quality as social sensitivity - the ability to understand subordinates, the causes of their actions, the role of each person in the group and the relationship between them. An important skill is also the ability to understand intonations, facial expressions, the human pantomime, the minimum number of external behavioral signs to guess the state of people, with great accuracy to assess the circumstances and factors that preceding this state, and based on intuitive assessment features of any person to predict his/her further behaviour.

The process of awareness, comprehension and reinterpretation of their own activities-so self-reflection is defined by Yu. Krasovskyi ${ }^{11}$. $\mathrm{He}$ also uses the term "reflexive management" - step-by-step understanding of feedbacks, which helps the chief to make managing decisions ahead of time, that is, taking into account the psychological reactions of employees. Speaking about the practical benefits of this process, he emphasizes that it must be valid for the manager. What is important is not self-analysis, but active actions in management in a new way based on your own imagined experiment. You can change yourself, your behavior only when the leader, having reached the "critical point", overcomes it meaningfully, but so that this work of consciousness could lead him to new horizons of his own selfimprovement (creative reflection).

Reflexive management, according to Yu. Krasovskyi, is such an overcoming of "critical points", after which both the head and the employees of his department form a rethought understanding of themselves in the same managerial situations. This is spontaneously fixed in certain phases of professional growth. The author writes about the possibility of managing this process with the help of special training methods, trainings, role-playing and business games focused on reflective processes.

10 Furman, A. V., Humeniuk, O. Y. (2006). Psykholohiia Ya-kontseptsii: Navchalnyi posibnyk [Psychology of self-concept: a textbook]. Lviv: Novyi Svit-2000, 306 p. [in Ukrainian].

${ }^{11}$ Morozov, I. V., Zalozh, V. V., Shyrobokov, S. M. (2003). Naukovi osnovy upravlinnia, Chastyna I. [Scientific Foundations of Management, Part I]. Khmelnytskyi.: Vydavnytstvo Natsionalnoi akademii DPSU, 150 p. [in Ukrainian]. 
Thus, the third aspect of the consideration of the importance of reflexive processes is a reference to the possibility of their initiation and use in the training of managers.

Reflexive management can be especially clearly presented in roleplaying innovative games, which use special techniques and procedures of "cultivation" of new knowledge and cultural patterns of behavior together with the participants of the games (game school of V. Dudchenko, 80-90-ies of XX century).

The aim of the innovative game is to work out the sociopsychological conditions and creative transformation of the personality. Each participant must reconsider himself in the creative self-criticism of the personal "I" in the group solution of innovative problems. This is, according to Yu. Krasovskyi, the highest level of self-reflection, which is formed by group awareness, reflection and rethinking of their professional and personal capabilities.

We can summarize the point of view of Yu. Krasovskyi the following way. Each Manager passes such "critical points" which he somehow realizes, comprehends and rethinks as the implementation of their capabilities in various organizational situations. Thus, it is included in the process of reflexive control of their behavior, which can be modeled using special training techniques.

At reflexive management such reconsideration of administrative activity of the head in which five interconnected processes are combined is supposed.

- The transformation of direct managerial actions into a cooperative-partner feedback system, in which people could work on the basis of long-term interests rather than momentary, which would help to maintain their stability, that is, consistency.

- The performance of such roles by the manager, as well as his employees, would expand and enrich external and internal contacts. As a means of ensuring success in such activities, the author considers participation in specialized role-playing games that help staff to comprehend themselves in new personifications, trying on the "costumes" of different characters (reasoning for another person). It teaches managers to understand the role positions of others, which is very important in the organization of interaction zones. The motto of such games is "Cognize others through yourself and yourself through others...". 
- Reassessment of their responsibilities, opportunities, desires and aspirations in changing situations of partnership, where some win, others lose, and others remain unchanged. There is a more in-depth understanding of themselves, a more correct understanding of business partners, a clearer understanding of how partners perceive themselves, and a clearer understanding of how partners perceive the manager. Interpersonal conflicts, according to Yu. Krasovskyi, arise precisely because employees misunderstand business partners; they do not understand how partners perceive themselves; they do not understand how and why partners perceive themselves in this way.

- Restructuring of management relations of the head in the new organization of joint business partnership on long-term interests and final results with delegation of powers "from the bottom up" and "from the top down". This means the creation of fundamentally new communication networks in which the concept of resource management should prevail. The creation of communication networks in business games helps managers to understand the multidimensional reflective world of assessments and self-assessments and as a result to really rebuild the conditions of future activities.

- Re-orientation of the head from one system of managerial values to another, which fixes a new way of thinking and behavior in his "communicative space" and time perspective. This system of value orientations "leads" the leader "from within" after his reflexive insight: "So it is impossible to work like that anymore!".

To help the officer in the effort to understand what prevents from effective work and how to change the activity, can techniques that work in the mode of reflexive drop. Posing such questions as:" What prevents, and what helps to take the initiative?", "What happens if nothing changes in the management of the unit?" - helps the border guard officer to plunge into a reflexive search, to abandon old stereotypes and find new value orientations.

This is happening especially intense if, in the process of training, officers are involved into specially organized situations with a plot that would inevitably lead them to "critical points" when it is necessary to make responsible decisions based on past experience of joint search for an original idea. At the same time, reflexive control is associated with paradoxes. 
An example of this can be the elements of the scenario of reflexive educational immersion, when the leader can set the task of constructing a new activity, and the head is forced to fix psychological barriers to it, as a result of which he is aware of the change in the conditions of his usual activity. When setting the task to work in a new organizational mode, the transition to a new qualitative state is consolidated and the awareness of their capabilities in the new activity takes place. The task of expanding the area of new organizational interaction helps to identify a different content of activities compared to what was before. The psychological phenomenon accompanies selfdetermination in a new understanding of management situations: "I work for the future", "I no longer waste time in current affairs". This is how the process of self-assessment is constructed, in which the organizational culture of management is transformed into sociopsychological phenomena of changes in the content of professional activity of border guard officers.

Thus, the study of how the activity of a border guard officer changes as a result of reflexive training allows us to draw conclusions about the significant impact of self-assessment on the effectiveness of management activities, which, in turn, requires additional research.

\section{Formation of professional self-assessment of border guard officers}

Modern democratization of society requires new approaches to the personality of the military leader. Complication of tasks assigned to heads of different levels of the State Border Guard Service of Ukraine predetermines their collective decision and understanding of possible consequences $^{12}$.

Self-assessment allows the border guard officer not to focus on himself, his own experiences, and take into account the attitude of other people to himself in order to adjust their own behavior. As practice shows, many border guard officers do not know how to reflect and do not know their level of professional characteristics. This causes

${ }^{12}$ Shreder, H. A. (1994). Rukovodit soobrazno situaci [Manage according to the situation]. M., 1994., 160 p. [in Russian]. 
difficulties in communicating of the border guard officer with his subordinates, conflict situations, etc.

Certain aspects of professional self-assessment have become the subject of research by psychologists E. Bern, A. Derkach, N. Kuzmina, A. Karpova, Ye. Potapchuk, M. Tomchuk, O. Safina, V. Yagupova, T. Yatsenko ${ }^{13,14,15}$. However ways of its acquiring by the border guard officers taking into account special conditions of their activity weren't considered.

Our study first of all considers the issue of professional activity of a border guard officer, which differs from the activity of an officer of the Armed Forces of Ukraine. The main activities in the state border protection units are operational and service activities and daily operations, the results of which are affected by the certain conditions.

At the current stage of development of the State Border Guard Service of Ukraine the issue of effective organization of management of border guard officers is becoming more and more important. Contract service and regular servicemen, a wide range of educational and age range of personnel and consideration of gender differences all complicate the professional activities of a border guard officer. The main difficulties for the officers graduating from the NASBGSU are caused by the organizational and management function related to the collection, analysis and processing of operational and service information, making the appropriate and correct decision, organization of its implementation, selection of adequate forms and methods of professional psychological impact, implementation of effective control. This, in turn, requires the officer to have a developed self-esteem to achieve the best result.

For the description of the model we took into account that its researchers define it as a certain chosen method of "replacement" of the object of study ${ }^{16}$.

13 Orban-Lembryk, L. E. (2003). Psykholohiia upravlinnia [Management Psychology]. Kyiv: Akademvydav, 567 p. [in Ukrainian].

${ }^{14}$ Potapchuk, Y. M. (2003). Viiskova psykholohiia [Military Psychology]. Khmelnytskyi.: Vydavnytstvo NAPVU, 149 p. [in Ukrainian].

15 Iahupov, V. (2004). Viiskova psykholohiia [Military Psychology]: Pidruchnyk. K.: Tandem, 656 p. [in Ukrainian].

${ }^{16}$ Metodiki socialno-psihologicheskoj diagnostiki lichnosti i gruppy [Methods of social and psychological diagnostics of the individual and the group]. (1990). M.: AN SSSR, In-t psikholohii, 219 p. [in Russian]. 
In the structure of the professional reflection model of a border guard officer, we have identified three main components of reflection:

1) Cognitive component of professional reflection, the main indicators of which are the self-analysis of their own professional knowledge, qualities, abilities to manage subdivisions and border guards;

2) Emotional-evaluation component of professional reflection, the main indicators of which are emotional response to the results of professional activity, sense of responsibility, patriotism, satisfaction with the results of professional activity;

3) Behavioural component of professional reflection, the main indicators of which are the understanding of professional actions, behavior, adequacy of own managerial decisions, compliance of actions and behavior with the requirements of the operational environment.

The personality structure of officers with a high level of professional self-esteem differs significantly from that of officers with a low level of professional self-esteem. Taking into account the fact that decision-making processes are a key aspect of management activity, reflexion should be considered as a component of the personality structure of a border guard officer.

The analysis of the practice of border guard officers studying at the National Academy of the State Border Guard Service and state border protection agencies shows that the majority of attention in this process is paid to practical and technical activities, and the main drawbacks in operational and service activities are related to management activities.

In order to determine the state of development of professional self-assessment of border officers, a stating experiment was carried out in the course of which the necessity of forming an influence on the components of professional self-assessment of a border officer was revealed.

It has been established that graduate officers have the lowest level of professional self-esteem. This is due to the fact that young officers are not yet aware of themselves as management officers, and during the first year they are adapted to the special conditions of the border guards. Among other officers, a high number of those who work directly with unit personnel, often operate in volatile operational 
environments and make responsible decisions. Rather high figures were shown by the officers, students of the operational-tactical faculty of NASBGSU, which can be explained by the fact that they had passed a special professional selection before joining.

The program for the formation of professional self-esteem was created. The content of it is outlined in Fig. 1.

\begin{tabular}{|c|c|c|c|}
\hline № & Name of the event & $\begin{array}{l}\text { Amount } \\
\text { of hours }\end{array}$ & $\begin{array}{c}\text { Formation } \\
\text { of reflection } \\
\text { components }\end{array}$ \\
\hline \multirow{5}{*}{1} & Course of lectures: & & \\
\hline & $\begin{array}{l}\text { Lecture 1: The essence of the professional } \\
\text { self-assessment of a border guard officer }\end{array}$ & 1 & Cognitive \\
\hline & $\begin{array}{l}\text { Lecture 2: The Impact of Professional } \\
\text { Self-Esteem on the Management Activity } \\
\text { of an Officer }\end{array}$ & 1 & Cognitive \\
\hline & $\begin{array}{l}\text { Lecture 3: Objective indicators and self- } \\
\text { assessment of professional activity of } \\
\text { border guards }\end{array}$ & 1 & Cognitive \\
\hline & $\begin{array}{l}\text { Lecture 4: Ways to Form a Professional } \\
\text { Self-Assessment of a Border Guard } \\
\text { Officer }\end{array}$ & 1 & Cognitive \\
\hline 2 & $\begin{array}{l}\text { Round table discussion, analysis and } \\
\text { reflection of problem situations, comp- } \\
\text { lex tasks in managing the operational and } \\
\text { operational activities of the unit }\end{array}$ & 2 & $\begin{array}{l}\text { Cognitive } \\
\text { Emotionally } \\
\text { valuable }\end{array}$ \\
\hline 3 & $\begin{array}{l}\text { Group session on introspection of levels } \\
\text { of individual professional reflection }\end{array}$ & 2 & $\begin{array}{l}\text { Cognitive } \\
\text { Emotionally } \\
\text { valuable } \\
\text { Behavioral } \\
\end{array}$ \\
\hline 4 & $\begin{array}{l}\text { Business game for solving situational } \\
\text { problems of management activity in } \\
\text { changes of operational situation on the } \\
\text { state border }\end{array}$ & 2 & $\begin{array}{l}\text { Cognitive } \\
\text { Emotionally } \\
\text { valuable } \\
\text { Behavioral } \\
\end{array}$ \\
\hline \multirow[t]{2}{*}{5} & $\begin{array}{l}\text { Training on formation of professional } \\
\text { self-assessment of a border guard officer }\end{array}$ & 54 & $\begin{array}{l}\text { Cognitive } \\
\text { Emotionally } \\
\text { valuable } \\
\text { Behavioral } \\
\end{array}$ \\
\hline & & $\begin{array}{l}\text { In total: } \\
64 \text { hours }\end{array}$ & \\
\hline
\end{tabular}

Fig. 1. The Program for the Formation of Professional Self-esteem of Border Guards 
The model of formation of professional self-esteem is shown in fig. 2 .

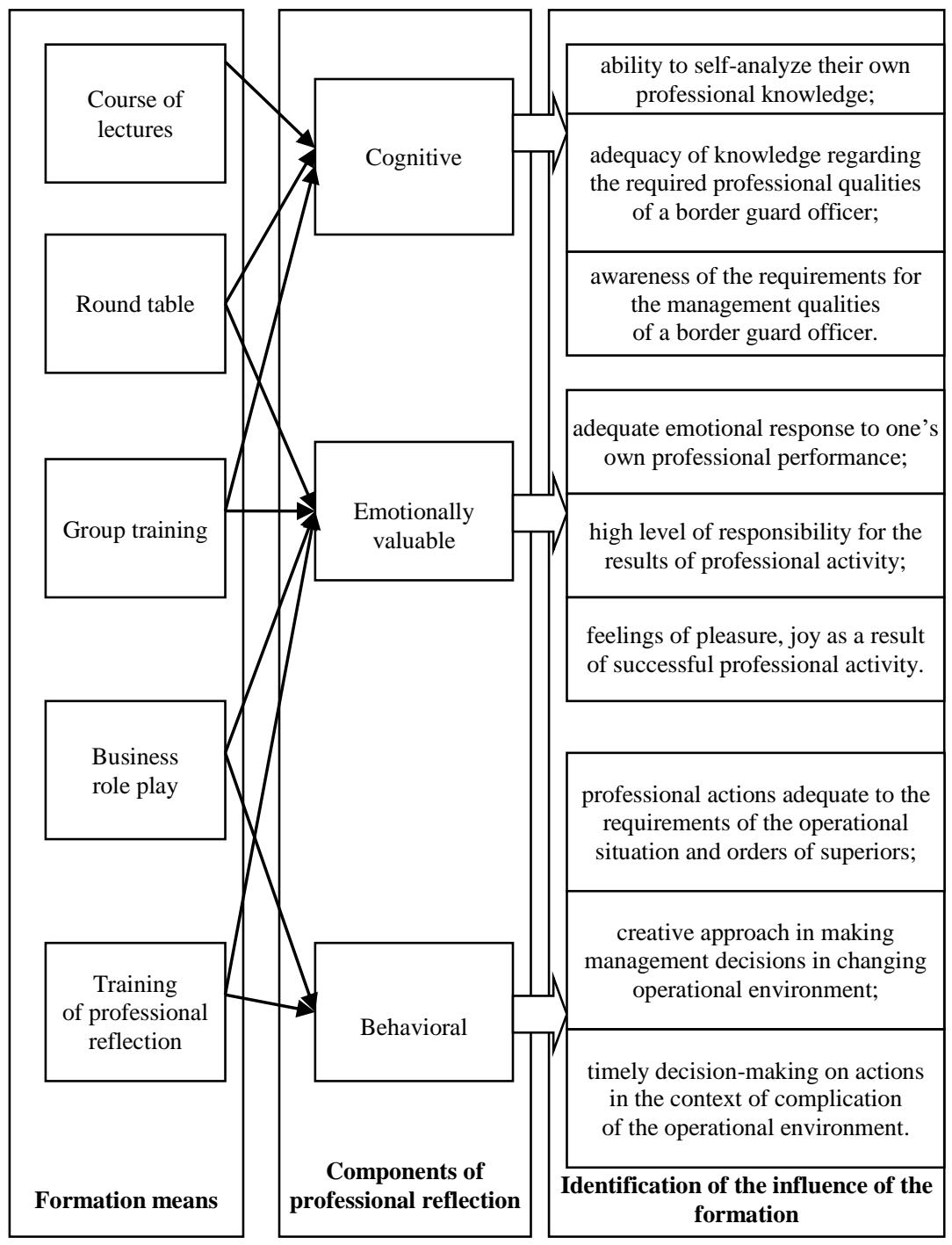

Fig. 2. The Model of Professional Self-assessment Formation of the Border Guard Officer 


\section{CONCLUSIONS}

1. There is a clear relationship between the level of self-esteem and the management characteristics of the border guard officer.

2. Socio-psychological characteristics of management activity in parts and subdivisions of the State Border Guard Service of Ukraine, the need to take into account democratic values in connection with its reform and approximation to European standards lead to an increase in the demand for the personal qualities of border guards officers, their ability to take into account the opinions of other experts and people in their professional activity.

3. Since decision-making processes are a key element of managerial activity, self-esteem must be considered as a part of the personality of the border guard officer.

4. The personality structure of officers who have a high level of professional self-esteem development is significantly different from the personality structure of officers who have a low level of professional self-esteem development.

5. Thus, the components of the model of formation of the professional self-assessment of the border guard are: means of influencing the components of the professional reflection of the border guard (set forth in the program of formation of the professional selfassessment of the border guard), the components of the professional self-assessment of the border guard, which are affected performance indicators that allow predicting the impact of the impact on the professional self-esteem of the border guard officer (Fig. 2).

The development of this model can effectively organize the work on the development of the professional self-assessment of the border guard officer and significantly increase the efficiency of his professional activity. In the following, we used the model and the experimental data to develop recommendations to the heads of different structures of the SBGS regarding the development of the professional self-assessment of a border guard officer.

\section{SUMMARY}

The article is devoted to analysis of the scientific papers presenting results of research on the concept of "self-esteem of a border guard officer" in the system of his professional activity and creation of a program and model of its formation. The components of 
the model of professional self-assessment formation of the border guard officers include means of influencing the components of the professional reflection of the border guard officers (outlined in the program of forming the professional self-assessment of the border guard officers), the components of professional self-assessment of the border guard officers, and the performance indicators. They make it possible to predict the impact on the border guard officer's professional self-assessment formation. The development of this model can effectively organize the work on the formation of the professional self-assessment of the border guard officer and significantly increase the efficiency of his professional activity. In the future, we used the above mentioned model and the experimental data to develop recommendations for the heads of different structures of the SBGS regarding the development of the professional self-assessment of a border guard officer.

\section{REFERENCES}

1. Morozov, I. V., Zalozh, V. V., Shyrobokov, S. M. (2003). Naukovi osnovy upravlinnia, Chastyna I. [Scientific Foundations of Management, Part I]. Khmelnytskyi.: Vydavnytstvo Natsionalnoi akademii DPSU, 150 p. [in Ukrainian].

2. Smolskij, S. M., Filippov, L. I. (2005). Tri shaga k professii: nauka, disertaciya, pedagogika [Three steps to the profession: science, dissertation, pedagogy]. Odessa: "Neptun-Tehnologiya", 125 p. [in Russian].

3. Potapchuk, Y. M. (2004). Teoriia ta praktyka zberezhennia psykhichnoho zdorovia viiskovosluzhbovtsiv: Monohrafiia [Theory and practice of maintaining the mental health of servicemen: A monograph]. Khmelnytskyi: Vydavnytstvo Natsionalnoi akademii DPSU, 323 p. [in Ukrainian].

4. Safin, O. D. (1997). Psykholohiia upravlinskoi diialnosti komandyra: navchalnyi posibnyk [Psychology of commander's management activity: a textbook]. Khmelnytskyi: Vydavnytstvo Akademii PVU, 149 p. [in Ukrainian].

5. Furman, A. V., Humeniuk, O. Y. (2006). Psykholohiia Ya-kontseptsii: Navchalnyi posibnyk [Psychology of self-concept: a textbook]. Lviv: Novyi Svit-2000, 306 p. [in Ukrainian]. 
6. Manhutov, Y. S., Umanskyi, L. Y. (1975). Orhanizator i orhanizatorskaia deiatelnost [Organizer and organizing activity]. Lviv, 310 p. [in Russian].

7. Metodiki socialno-psihologicheskoj diagnostiki lichnosti i gruppy [Methods of social and psychological diagnostics of the individual and the group]. (1990). M.: AN SSSR, In-t psikholohii, 219 p. [in Russian].

8. Orban-Lembryk, L. E. (2003). Psykholohiia upravlinnia [Management Psychology]. Kyiv: Akademvydav, 567 p. [in Ukrainian].

9. Potapchuk, Y. M. (2003). Viiskova psykholohiia [Military Psychology]. Khmelnytskyi.: Vydavnytstvo NAPVU, 149 p. [in Ukrainian].

10. Iahupov, V. (2004). Viiskova psykholohiia [Military Psychology]: Pidruchnyk. K.: Tandem, 656 p. [in Ukrainian].

11. Shreder, H. A. (1994). Rukovodit soobrazno situaci [Manage according to the situation]. M., 1994., 160 p. [in Russian].

\section{Information about the author: Valentyn Demskyi}

Head of Psyhology and Moral and Psyhological Support Department National Academy of the State Border Guard Service of Ukraine named after Bohdan Khmelnytskyi 46, Shevchenko str., Khmelnytskyi, 29003, Ukraine ORCID ID: orcid.org/0000-0003-4777-9392 


\section{MAINTAINING THE MENTAL HEALTH \\ OF THE BORDER GUARDS IN SPECIAL AND/OR EXTREME \\ CONDITIONS OF THEIR PROFESSIONAL ACTIVITY \\ BY MEANS OF THE PASTORAL ACTIVITY \\ OF THE MILITARY CHAPLAINS}

\section{Artem Makovskyi}

"Religious faith made sense of life even in the terrible conditions of Auschwitz" Viktor E. Frankl

\section{INTRODUCTION}

Today, in the period of socio-historical and socio-economic upheavals, there is a significant increase in extreme psychological situations in the everyday life of the Ukrainian citizens, which are characterized by significant influence on the human psyche of sociopsychological factors related to the threat to life, health or social wellbeing, the psychological consequences of which are manifested in occurrence of various kinds of negative psycho-emotional reactions, both in the Ukrainian society in general and among the border guards in particular. The undeniable fact is the one that the constant threat to life, combat wounds or contemplation of death are extraordinary psycho-traumatic factors, which determine the border guards' stress that can transform into a psychological trauma and lead to mental health disorders.

According to the definition of the World Health Organization "mental health" is a level of mental well-being, which is determined not only by the absence of mental illnesses, but also by a number of socio-economic, biological and environmental factors ${ }^{1}$ ("Vsesvitnia orhanizatsiia okhorony zdorovia", 2019).

1 Vsesvitnia orhanizatsiia okhorony zdorovia [World Health Organization]. Retrieved from: https://www.who.int/ru/news-room/fact-sheets/detail/mental-healthstrengthening-our-response [in Ukrainian]. 
The "Psychological Dictionary" gives the following definition of the concept of "mental health": "a state of a person's mental wellbeing, which is characterized by the absence of painful mental manifestations and provides the regulation of his behavior and activity in adequate conditions of reality"2 (Pobirchenko, 2007). Considering the multidimensionality, diversity of the psyche, Ye. Potapchuk distinguishes the basic components or types of a person's mental health: a mental type - the ability to receive, analyze and use the necessary information; an emotional type - the ability to understand, express and regulate one's own emotions and feelings; a practical one - the ability to understand one's own needs and interests, to set appropriate goals and achieve them ${ }^{3}$ (Potapchuk, 2004).

Having analyzed the scientific works of the Ukrainian military psychologists, we came to the conclusion that the concept of "mental health of a border guard" should be considered as such a way of his psyche functioning, which provides a harmonious interaction with the outside world, the adequacy of behavior, the effectiveness of educational and service activities, personal development ${ }^{4}$ (Aleshchenko, Safin, \& Potapchuk, 2007).

Studies of warfare experience indicate that the mental health of the border guards is positively influenced by the formed combat skills, voluntary participation in combat operations, integration into the unit, high moral climate in the unit, religiosity or belief in war justice, high self-esteem and intelligence. Due to the objective lack of a sufficient number of specialists, i.e. psychologists with practical experience in the border guard units, the approach to psychological prevention and psychological correction of psychological trauma of the personnel of

${ }^{2}$ Pobirchenko, N. A. (Red.). (2007). Psykholohichnyi slovnyk [Psychological Dictionary]. Kyiv: Naukovyi svit [in Ukrainian].

${ }^{3}$ Potapchuk, Ye. M. (2004) Sotsialno-psykholohichni osnovy zberezhennia psykhichnoho zdorovia viiskovosluzhbovtsiv [Socio-psychological bases of maintaining mental health of military personnel]. (Dys. d-ra psykhol. nauk) Natsionalna akademiia Derzhavnoi prykordonnoi sluzhby im. B. Khmelnytskoho, Khmelnytskyi [in Ukrainian].

${ }^{4}$ Aleshchenko, V. I., Safin O. D., Potapchuk Ye. M. (2007). Orhanizatsiia zabezpechennia zberezhennia psykhichnoho zdorovia viiskovosluzhbovtsiv [Organization of maintenance of mental health of military personnel]. Kyiv [in Ukrainian]. 
the State Border Guard Service of Ukraine remains unavoidably formal. Therefore, in our opinion, during the conduct of psychoeducational, informative-propagandist and psycho-prophylactic measures with border guards, the potential of military chaplains, who have been providing pastoral care for the military personnel on a regular basis for the last three years, should be used more actively.

First of all, it is necessary to find out who a military chaplain is and how he differs from a parish priest.

1. A military chaplain is a priest or a spiritual leader of a religious community. He can be a pastor, a minister, a rabbi, an imam. In some Protestant churches he is a deacon with the priesthood authority.

2. A military chaplain is associated with a particular denomination or a religious organization and he is its representative in the army. But he gives spiritual support to people of any religion neither imposing his religious views on others nor giving up his own beliefs.

3. A military chaplain gives spiritual support to a group of people who do not represent a church, religious, or missionary community. By the silent agreement, a kind of world code of military chaplaincy, the army cannot be a field of missionary activity.

4. A military chaplain is no ordinary priest. He received a special training in the field of pastoral care of soldiers. There is no generally accepted standard (among states, denominations, or even just educational institutions) for training military chaplains. In some church educational institutions, he may be trained as a psychologist purposefully.

5. A chaplain usually gives spiritual support to everyone, regardless of his faith or its lack.

6. A military chaplain operates in a particular human environment. His congregation is physically strong, active, armed, and (on the general public background) highly aggressive ${ }^{5}$ (Kalenychenko, \& Kokhanchuk, 2017).

We suggest considering a few problematic aspects in the moral and psychological support of the border guards where, in our opinion,

${ }^{5}$ Kalenychenko, T., Kokhanchuk, R. (2017). Buty poruch. Osnovy viiskovoho kapelanstva dlia viiskovykh $i$ volonteriv [To be near. Basics of military chaplaincy for military personnel and volunteers]. (2-e vydannia). Kyiv: Makhanaym Prynt [in Ukrainian]. 
it is necessary to activate the pastoral activities of military chaplains in order to maintain the mental health of the personnel in special and/or extreme conditions of their professional activity.

\title{
1. Psychological prevention of deviant behavior of the border guards in special and/or extreme conditions of their professional activity by means of pastoral activity of military chaplains
}

\author{
"Chaplains are strong-minded people \\ who dress the Ukrainian army in the armor of light" \\ His Beatitude Sviatoslav
}

Over the last five years, more than 17,000 border guards have participated in hostilities in the East of the country that are characterized by a significant impact on their psyche of socio-psychological factors related to the threat to life, health or well-being, the psychological effects of which are expressed in different forms of deviant behavior.

In the Great Interpretive Dictionary of Modern Ukrainian, deviance is defined as social behavior that deviates from what is considered normal or socially acceptable in the society or in a social context $^{6}$ (Busel, 2005). In psychological dictionaries, deviant behavior is defined as:

Deviant behavior is behavior that violates the social norms of a particular society ${ }^{7}$ (Reber, 2003).

Deviant behavior includes actions that do not conform to officially established or actually formed in this society (social group) norms and leads the offender to isolation, treatment, correction or punishment $^{8}$ (Meshcheryakova, \& Zinchenko, 1983).

At the roots of sociology of deviant behavior there was French scientist Emile Durkheim (1858-1917), the creator of the French

\footnotetext{
${ }^{6}$ Busel, V. T. (Red.). (2005). Velykyi tlumachnyi slovnyk suchasnoi ukrainskoi movy [A great explanatory dictionary of modern Ukrainian]. Kyiv: Perun [in Ukrainian].

${ }^{7}$ Reber, A. (Red.). (2003). Bolshoy tolkovyy psikhologicheskiy slovar [Great explanatory psychological dictionary]. (T. 1 (A-O)). Moskva: AST [in Russian].

${ }^{8}$ Meshcheryakova, B. G., Zinchenko, V. P. (Red.). (1983) Psikhologicheskiy slovar [Psychological Dictionary]. Moskva: AST [in Russian].
} 
sociological school. He put forward the concept of social anomie, defining it as "a state of society when old norms and values do not correspond to real relations anymore and new ones have not been established yet". In his opinion, anomie is a consequence of crises and different social changes and it describes such a situation in a society that is characterized by the weakening or destruction of norms, the contradictions of the rules, which regulate social relations. As a result, individuals lose their social orientation, which contributes to the development of their deviant behavior. Thus, in his work "Suicide" Durkheim noted that during the periods of social declines and upsurges, the number of suicides increased, showing that social disorganization is the cause of deviant behavior ${ }^{9}$ (Durkheim, 1994).

The opinion of I. Kon is that deviant behavior is a system of actions that deviate from the accepted norm or the implied one (mental health, rights, morals) ${ }^{10}$ (Kon, 1997).

M. Kikalishvili proposes the following definition of deviant behavior: it is a person's stable behavior, which deviates from the most important social norms and causes real harm to the society or the person himself, and is accompanied by his social maladaptation ${ }^{11}$ (Kikalishvili, 2001).

The special features and factors of deviant behavior of a person are widely described in the theory of psychology: firstly, in the process of age development (L. Vygotskyi, E. Erikson, Yu. Kleiberg, O. Rean, H. Remscheid); secondly, in the process of adaptation to the environment (V. Mendelevich, Yu. Platonov, etc.); thirdly, in connection with the development of methods of socio-psychological prevention and correction of individual-psychological manifestations of deviant behavior (O. Zmanovska).

9 Durkheim, E. (1994). Samoubiystvo: Sotsiologicheskiy etyud [Suicide: A sociological study]. Moskva: Mysl [in Russian].

${ }^{10}$ Kon, I. S. (1997). Vkus zapretnogo ploda [The taste of the forbidden fruit]. Moskva: Semya i shkola [in Russian].

${ }^{11}$ Kikalishvili, M. (2001). Deviantna povedinka: poniattia ta oznaky [Deviant behavior: concepts and features]. Visnyk Akademiii advokatury Ukraiiny [Bulletin of the Academy of Advocacy of Ukraine], 3(22), 109-122. Retrieved from: irbisnbuv.gov.ua > cgi-bin > irbis_nbuv > cgiirbis_64 > vaau_2011_3_17 [in Ukrainian]. 
Deviant behavior is generally the subject of scientific analysis in many studies by foreign psychologists and is considered as: the result of insufficient containment of internal tension that requires discharge; the consequence of hypercompensation of needs (A. Adler, Z. Freud, E. Fromm); the result of social learning (A. Bandura); the consequence of frustration (J. Dollard, N. Miller); a consequence of the blockade of self-actualization needs (A. Maslow), etc.

The manifestations of deviant behavior of the military personnel were researched by modern scientists: V. Aleshchenko, O. Blinov, O. Boiko, O. Makarevych, Ya. Melnyk, V. Osodlo, I. Prykhodko, A. Romanyshyn, V. Timchenko, V. Yahupov and others.

According to I. Kon, persons with deviant behavior are divided into two broad categories. The first category includes those persons, whose behavior deviates from mental health standards, i.e. it can be confirmed that they have manifested or hidden psychopathology. The second category comprises those persons with asocial (delinquent) behavior, the special feature of which is the violation of social, cultural and legal norms ${ }^{12}$ (Kon, 1967).

The well-known researcher in the field of deviant behavior typology A. Lychko classifies deviant behavior according to the following directions:

1) by the form: delinquent behavior, home escape, early alcoholism, sexual deviance, suicidal behavior;

2) by reasons, factors, motives: genetic inheritance, residualorganic brain damage, phenomena of acceleration and infantilism - on the one hand, and sociopsychological factors - on the other hand ${ }^{13}$ (Lichko, 1983).

According to Ya. Melnyk, deviant behavior of the military personnel is a socio-psychological phenomenon, the content base of which is a violation of social-psychological interaction of a military man with the military and social environment, which is caused by inconsistencies in the system of "person - military-social environment"

${ }^{12}$ Kon, I. S. (1967). Sotsiologiya lichnosti [Sociology of personality]. Moskva: Politizdat [in Russian].

${ }^{13}$ Lichko, A. Ye. (1983). Eti trudnyye podrostki [These difficult teens]. Moskva: Meditsina [in Russian]. 
that are defined by his actions and deeds that do not comply with the military organization norms ${ }^{14}$ (Melnyk, 2016).

A considerable number of offenses and negative phenomena in combat units actualizes the task of preventing and overcoming deviant behavior of the border guards in special and/or extreme conditions of their professional activity. The large number of suicides is of particular concern.

Suicidal behavior is a self-destructive behavior that also includes such forms of deviant behavior as alcohol abuse, drug use, stubborn unwillingness to be treated, drunk driving, self-torture, conscious participation in fights, etc ${ }^{15}$ (Romanyshyn, 2017).

According to statistics, more than 800,000 people die in the world annually as a result of suicides, i.e. one person every 40 seconds (one of the most vulnerable groups is the youth $)^{16}$ (Ovcharova, \& Movchan, 2018). According to the State Statistics Service in Ukraine, in 2015-2016, 14773 persons committed suicides. Currently, the suicide is the second leading cause of death for people aged 15 to 29 in the world ${ }^{17}$ (Derzhavna sluzhba statystyky Ukrainy, 2018). According to official figures, more than 500 Ukrainian military men have committed suicide since the beginning of hostilities in the East of the country ${ }^{18}$

14 Melnyk, Ya. I. (2016). Psykhoprofilaktyka deviantnoi povedinky viiskovosluzhbovtsiv v osoblyvykh umovakh diialnosti [Psychoprophylaxis of deviant behavior of military personnel in special conditions of activity]. (Dys. kand. psykhol. nauk). Natsionalna akademiia Derzhavnoii prykordonnoii sluzhby im. B. Khmelnytskoho [in Ukrainian].

15 Romanyshyn, A. M. (Red). (2017). Profilaktyka vidkhylnoi povedinky $u$ viiskovosluzhbovtsiv [Prevention of deviant behavior of military personnel]. Lviv: NASV [in Ukrainian].

16 Ovcharova, L., Movchan, A. (2018.). Technologies of social work with persons easy to suicide REPORTER OF THE PRIAZOVSKYI STATE TECHNICAL UNIVERSITY Section: Socially-humanitarian sciences and public administration, 1, 119-122 [in English].

${ }^{17}$ Derzhavna sluzhba statystyky Ukrainy [State Statistics Service of Ukraine]. (2018). Lyst [Letter]. Retrieved from: ps://dostup.pravda.com.ua/request/34337/ response/76881/attach/2/15.2\%2020\%20770.pdf [in Ukrainian].

18 Samohubstva v armii [Suicide in the Army]. (2018, liutyi 26). Ukrainska Pravda [The Ukrainian Truth]. Retrieved from: https://www.pravda.com.ua/news/ 2018/02/26/7172855 [in Ukrainian]. 
("Samohubstva V armii", 2018). According to unofficial information, this number is much higher ${ }^{19}$ ("Vlada znaie ne vse...", 2018).

Most European countries use the definition adopted by the Working Group on Suicide Prevention and Suicide Attempts at the World Health Organization's Regional European Office: "Suicide is an act with fatal outcome that was initiated and executed by the one, who died, deliberately in an awareness and expectation of fatal result by which the deceased realized the desired change". Thus, the suicide is an escape from the reality, which is perceived as hostile (from the point of view of the suicide committer) and the point of suicide is to solve all problems irrevocably. Among the factors, which contribute to thoughts about suicide, are social isolation, lack of support from relatives and friends in a difficult situation, problems at military service, problems of interpersonal relationships, etc.

The researchers in the field of military psychology usually distinguish the following types of a suicide:

- real (conscious, "steadfast", planned, purposeful);

- affective (it occurs under the influence of a sudden psychotraumatic event);

- demonstrative (does not include committing suicide $)^{20}$ (Karayani, 2006).

Unfortunately, all these types of suicides also occur in the State Border Guard Service of Ukraine. By its nature, suicide among the border guards is usually a form of infantile escape from a psychotraumatic situation.

Therefore, the psychoprophylaxis is one of the most important areas of work on suicide prevention for the management staff of the border guard unit, a psychologist, a military chaplain and its success depends mainly on their ability to recognize the signs of suicidality in the behavior of the border guard. Practice has shown that a border

19 Vlada znaie ne vse... [The authorities do not know everything...] OBOZREVATEL.ua. [OBSERVER.ua] Retrieved from: https://www.obozrevatel.com/ $\mathrm{ukr} /$ crime/statistika-zanizhena-veteran-ato-rozpoviv-pro-vbivstva-i-suitsidi-v-armii.htm [in Ukrainian].

20 Karayani, A. G. (2006). Prikladnaya voyennaya psikhologiya [Applied Military Psychology]. Sankt-Peterburg: Piter [in Russian]. 
guard who is about to commit suicide, consciously or unconsciously, tries to inform others about the trouble in which he found himself as well as about a possible act of suicide. Among the signs of a possible suicide committing, the researchers single out the most common ones such as depression; oral or written hints which include considerations about suicide; stories about their problems; asking for help. Inattention to the problems of the border guard by the commander, the military chaplain, his comrades, his relatives and friends is an obstacle for responding to such signals in time.

Another type of deviant behavior that needs greater attention of commanders is the addictive behavior that results from substance abuse which change a person's mental state (alcohol, drugs, toxic substances) $^{21}$ (Romanyshyn, 2017). In all its various manifestations, addictive behavior, which is basically a distorted form of adaptation, overcoming anxiety, insecurity, social uncertainty, striving for selfaffirmation, can be considered a response to unfavorable living conditions and military service conditions. The most common form of addictive behavior among the military personnel is alcohol abuse, which, from a psychological point of view, is a kind of compensation, an attempt to disengage from a situation of lethal danger psychologically, to overcome fear, to forget about losses, etc. Unfortunately, some military men believe that the recovery from stress, the removal of psychological burden with alcohol is one of the most effective problem solutions. The commanders and psychologists of military units may not always be able to carry out effective psychoprophylactic measures aimed at preventing drinking As the practice of involving some chaplains by commanders in the fight against drinking in military units has shown, it has a positive effect.

The difficult circumstances in life that lead to frustration bring people closer to religion that becomes their means of hypercompensation. Mostly the combatants get interested in religion while they are in such a state. W. James noticed that religion has the wonderful power to turn the most enduring sufferings of the human

21 Romanyshyn, A. M. (Red). (2017). Profilaktyka vidkhylnoi povedinky u viiskovosluzhbovtsiv [Prevention of deviant behavior of military personnel]. Lviv: NASV [in Ukrainian]. 
soul into the deepest and most intimate happiness ${ }^{22}$ (Predko, 2005). The representatives of the humanistic approach in psychology, American scientists A. Maslow, C. Rogers, H. Kohut, came to the conclusion that the religiosity of a person influences his selfrealization, self-actualization, self-transcendence positively and it helps many people to realize their calling, realize their abilities, to choose a viable life strategy and tactics ${ }^{23}$ (Moskalets, 2004).

In the United States and Western European countries, psychological science has been using religion in psychoprophylactic activity thoroughly and effectively for a long time. In this activity, the role of the priest is decisive. Therefore, pastoral psychology has emerged as a separate branch of the psychology of religion in these countries. It is a branch of knowledge, the main problem of which is the ways and means of effective psycho-regulatory influence of the clergymen on the human psyche. And the military chaplains, who carry out the pastoral care of military men, play traditionally an exceptional role in the system of working with the army personnel of the NATO member state.

The history of the Ukrainian armed formations contains many examples of close interaction between the state and the church in its chronicle. The issue of chaplain pastoral care in Ukraine is gaining more and more importance and relevance in connection with the hybrid war. Military chaplains influence the spiritual and patriotic state of the military men, their families, and the Ukrainian society as a whole, because during almost the whole history of independent Ukraine, the church as a social institution, has always been first in the trust rating of the Ukrainian citizens ${ }^{24}$ (Nepipenko, 2017). The results of the field

${ }^{22}$ Predko, O. I. (2005). Psykholohiia relihii: istoriia, teoriia, relihiieznavchi vymiry [Psychology of Religion: History, Theory, Religious Dimensions]. Kyiv: Tsentr navchalnoi literatury [in Ukrainian].

23 Moskalets, V. P. (2004). Psykholohiia relihii [Psychology of religion] : posibnyk. Kyiv: Akademvydav [in Ukrainian].

${ }^{24}$ Nepipenko, L. P. (2017). Problemy ta perspektyvy instytualizatsii viiskovoho dukhovenstva (kapelanskoi sluzhby) $v$ Ukraini [Problems and Prospects of Institutionalization of the Military Clergy (Chaplaincy Service) in Ukraine], Naukove zabezpechennia sluzhbovo-boiovoi diialnosti Natsionalnoi hvardii Ukrainy [Scientific Support for Service and Combat Activity of the National Guard of Ukraine], zb. materialiv dop. uchasn. VIII nauk.-prakt. konf. Kharkiv: NANHU. Retrieved from: 
researches and expert assessments, which were conducted by T. Kalenychenko, indicate that each of the interviewed military men who participated in the warfare, mentions the importance of the priest presence nearby. In addition to the importance of the pastor's constant presence with them on the front line (which is relevant during the open phase of the conflict), some young officers advise to focus on the work of chaplains with the cadets who become field commanders shortly after their graduation and learn to manage their military unit immediately on the front line $\mathrm{e}^{25}$ (Kalenychenko, 2018).

Thus, psychoprophylactic work is based on the early detection and correction of negative informational, psychological and organizational factors of service and combat activity, which cause deviations in the psychological and social life of the border guards, in their behavior, health, and organization of their service and leisure activities. The Psychoprophylaxis of deviant behavior is a part of the program on its prevention, which cannot be carried out only by unit commanders and officers of educational structures, taking into consideration the foreign experience of the NATO armies. It is necessary to involve military chaplains as actively as possible in the psychoprophylaxis of suicidal and addictive behavior of the border guards, since religion has a powerful psychoprophylactic influence on the person's psyche, creating for him an opportunity to assert himself in the personal transcendent. The main psychoprophylactic effect of the pastoral care is the feeling of existential security as a consequence of suggesting the inevitability of the victory of good over evil, of life over death. At the same time, religion minimizes the source of existential anxiety, fear or even neutralizes it completely, it helps a person to establish himself psychologically in the highest authority that promises him protection from the threat of evil and death.

Thus, the pastoral activity of the military chaplains has a wide range of psychological techniques, capable of updating and adjusting

http://nangu.edu.ua/wp-content/uploads/2017/04/3бірник-тез-2017_секція-4.pdf [in Ukrainian].

25 Kalenychenko, T. A. (2018). Relihiina skladova suspilno-politychnoho konfliktu kintsia 2013-2017 rr. v Ukraini [The religious component of the sociopolitical conflict of the end of 2013-2017 in Ukraine]. (Dys. kand. filosof. nauk). Nats. ped. un-t. im. M.P. Drahomanova, Kyiv [in Ukrainian]. 
the subjective potential of the border guard and activating it for selfpreservation and protection of the Motherland.

\section{The prognostic model of the interaction of the subjects of moral-psychological support for maintaining the mental health of the border guards in special and/or extreme conditions of their professional activity}

According to the definitions of encyclopedic dictionaries, a model is considered as a diagram, depiction or description of any object, phenomenon or process in nature or society that are studied as their analogue (from Latin modulus - measure, sample) ${ }^{26}$ (Grishin, 1994). A model is any mental, symbolic or material image of the original (displaying objects and phenomena in the form of descriptions, theories, diagrams, drawings, graphs) ${ }^{27}$ (Prokhorov, 1991). The model is one of the central concepts of the theory of cognition, it is connected with the concepts of truth and thought, similarity, difference $^{28}$ (Shynkaruk, 1986). Model is a sample that reproduces, imitates the structure and action of any object; it is used to gain new knowledge about the object ${ }^{29}$ (Busel, 2005); model is a measure, a sample, a conditional image of something ${ }^{30}$ (Filonenko, 2015); model is a sign system with which you can reproduce the process, show the integrity of its structure, functioning and maintain that integrity at all the stages of the research ${ }^{31}$ (Spirina, 2008).

${ }^{26}$ Grishin, Ye. A. (Red). (1994). Sovremennyy slovar inostrannykh slov [Modern dictionary of foreign words]. Sankt Peterburg: Duyet [in Russian].

27 Prokhorov, A. M. (Red.). (1991). Bolshoy entsiklopedicheskiy slovar [Great Encyclopedic Dictionary]. Moskva: Sov. Entsiklopediya [in Russian].

${ }^{28}$ Shynkaruk, V. I. (Red). (1986). Filosofskyi slovnyk [Philosophical Dictionary] Kyiv: Holovna redaktsiia URE [in Ukrainian].

${ }^{29}$ Busel, V. T. (Red). (2005). Velykyi tlumachnyi slovnyk suchasno ukrainskoi movy [A great explanatory dictionary of modern Ukrainian]. Kyiv: Perun [in Ukrainian].

30 Filonenko, M. M. (2015). Psykholohiia osobystisnoho stanovlennia maibutnoho likaria [Psychology of personality formation of the future doctor]. Kyiv: Tsentr uchbovoii literatury [in Ukrainian].

31 Spirina, T. P. (2008). Model formuvannia profesiinoi kultury maibutnikh sotsialnykh pedahohiv [Model of professional culture formation of future social educators]. Visnyk Prykarpatskoho universytetu : pedahohika [Bulletin of the Carpathian University : Pedagogy], 21, 278-291 [in Ukrainian]. 
A scientific model is an imaginary or materially implemented system that adequately reflects the subject of the research and is able to change it in such a way that the study of the model facilitates to obtain new information about the subject. At the same time, the main advantage of modeling as a research method is the ability to cover the system holistically and it allows to improve its planning, to optimize the structure, to increase the process efficiency, to construct and interpret a new theory, to test the hypothesis of the research ${ }^{32}$ (Poplavska, 2009).

I. Levina defines a model as the construction of several constituents, the components of which are the subject (person); a task which is solved by the subject; the original object (fragment of reality) and the description language or the method of material reproduction of the model $^{33}$ (Levina, 2001).

The model gives an opportunity to understand what should be formed in comparison with what has already been formed. On the basis of the model, it is possible to formulate a general aspect of the process, transfer it into a theoretical plane, understand the structure and mechanism of interaction of the system under study better and it will ensure the reliability of processing the obtained results ${ }^{34}$ (Mykhailiuk, 2001).

Having generalized the experience of the scientists who dealt with modeling problems, I. Levina considered didactic functions of models and modeling, determined their essence and structure, carried out

${ }^{32}$ Poplavska, S. D. (2009). Model formuvannia hotovnosti studentiv medychnykh koledzhiv do komunikatyvnoi vzaiemodii u profesiini diialnosti [Model of forming the readiness of students of medical colleges for communicative interaction in the professional activity]. Visnyk Zhytomyrskoho DU im. I. Franka [Bulletin of I. Franko Zhytomyr State University], 46, 92-96 [in Ukrainian].

${ }^{33}$ Levina, I. A. (2001.). Profesiina diialnist uchytelia z formuvannia piznavalnoi samostiinosti pidlitkiv zasobamy modeliuvannia [Teacher's professional activity on forming of teenagers' cognitive independence by means of modeling]. (Dys. kand. ped. nauk.). Pivdennoukr. derzh. ped. un-t im. K. D. Ushynskoho, Odesa [in Ukrainian].

34 Mykhailiuk, I. R. (2001). Pedahohichni umovy ta model formuvannia hotovnosti do pedahohichnoi diialnosti mahistriv tekhnichnoho spriamuvannia [Pedagogical conditions and model of forming the readiness for pedagogical activity of masters of technical direction]. Visnyk Natsionalnoi akademii Derzhavnoi prykordonnoi sluzhby Ukrainy [Bulletin of the National Academy of the State Border Guard Service of Ukraine], 3, 21-27 [in Ukrainian]. 
classification of models, combining them into two large groups: material (physical and analog) and ideal (intuitive and symbolic) ${ }^{35}$ (Levina, 2001).

Sometimes even the formation of readiness for a particular activity is considered by scientists as a conceptual model of this activity (namely, an imaginary picture of the process and conditions of the activity), i.e. a dynamic synthesis of available information and previous experience. The principles of constructing such a model are:

- generalization (display of the most significant constant features of the modeling object);

- schematics (demonstration of the fundamental elements interrelation of a modeling object);

- panoramic feature (display of integrity through structural components) ${ }^{36}$ (Levina, 2001).

According to S. Melnyk, modeling consists of the following stages:

- setting the goal of solving the problem with the help of the model;

- identifying the main components of the system that make up its essence;

- revealing objectively existing interconnections between system components;

- translating the system components into the abstract language (symbolism);

- choosing the ways to depict the model and its construction $^{37}$ (Melnyk, 2006).

${ }^{35}$ Levina, I. A. (2001). Profesiina diialnist uchytelia z formuvannia piznavalnoi samostiinosti pidlitkiv zasobamy modeliuvannia [Teacher's professional activity on forming of teenagers' cognitive independence by means of modeling]. (Dys. kand. ped. nauk). Pivdennoukr. derzh. ped. un-t im. K. D. Ushynskoho, Odesa [in Ukrainian].

${ }^{36}$ Levina, I. A. (2001). Profesiina diialnist uchytelia $z$ formuvannia piznavalnoi samostiinosti pidlitkiv zasobamy modeliuvannia [Teacher's professional activity on forming of teenagers' cognitive independence by means of modeling]. (Dys. kand. ped. nauk.). Pivdennoukr. derzh. ped. un-t im. K. D. Ushynskoho, Odesa [in Ukrainian].

${ }^{37}$ Melnyk, S. V. (2006). Modeliuvannia diialnosti innovatsiinoho navchalnoho zakladu - Shkoly spryiannia zdoroviu [Modeling the activities of an innovative educational institution - Schools for health promotion]. Ridna shkola [Home School], 4, 25-29 [in Ukrainian]. 
Thus, modeling allows you to identify the components that make up a single system clearly, to build relations between them schematically, to highlight the forms, methods, systems of the result evaluation, to set the conditions for the object of the study.

Modeling is one of the main categories of the theory of cognition; any method of scientific research, both theoretical (which uses symbolic, abstract models) and experimental (uses subject models), is based on the idea of modeling ${ }^{38}$ (Prokhorov, 1991).

Modeling considers a real system in a set of elements that are interconnected in a particular way. According to the definition of philosophical dictionaries, a system (from Greek systema - composed of parts, combined) is a set of elements that are interconnected and which create a certain integrity, unity ${ }^{39}$ (Gubskiy, 1997); a system is an ordered set of interrelated elements that have their own structure and organization $^{40}$ (Shynkaruk, 1986). These definitions indicate that the concept of a system implies such notions as an element and a structure. An element is an indivisible system component in the context of a particular system and its specific consideration and analysis ${ }^{41}$ (Shynkaruk, 1986).

In I. Levina's research, modeling is considered as the research of objects of cognition on their models, the construction (analysis and study) of models and objects (systems, structures, processes, etc.). The author has defined the following main stages in modeling:

1) setting the task;

2) creating and selecting a model to study the original;

3) the model studying;

4) transferring the data obtained by analyzing the model to the original $^{42}$ (Levina, 2001).

${ }^{38}$ Prokhorov, A. M. (Red). (1991). Bolshoy entsiklopedicheskiy slovar [Great Encyclopedic Dictionary]. Moskva: Sov. Entsiklopediya [in Russian].

39 Gubskiy, Ye. F. (Red). (1997). Filosofskiy entsiklopedicheskiy slovar [Philosophical Encyclopedic Dictionary]. Moskva: INFRA [in Russian].

40 Shynkaruk, V. I. (Red). (1986). Filosofskyi slovnyk [Philosophical Dictionary] Kyiv: Holovna redaktsiia URE [in Ukrainian].

${ }^{41}$ Shynkaruk, V. I. (Red). (1986). Filosofskyi slovnyk [Philosophical Dictionary] Kyiv: Holovna redaktsiia URE [in Ukrainian].

${ }^{42}$ Levina, I. A. (2001). Profesiina diialnist uchytelia z formuvannia piznavalnoi samostiinosti pidlitkiv zasobamy modeliuvannia [Teacher's professional activity on forming of teenagers' cognitive independence by means of modeling]. (Dys. kand. ped. nauk.). Pivdennoukr. derzh. ped. un-t im. K. D. Ushynskoho, Odesa [in Ukrainian]. 
Developing the prognostic model of the interaction of the subjects of moral-psychological support for maintaining the mental health of the border guards in special and/or extreme conditions of their professional activity (Fig. 1), we have used a systematic approach that “... in psychology ... allows to integrate and systematize the accumulated knowledge, to overcome their extreme redundancy, to find invariants of psychological descriptions, to bypass the local approach disadvantages, to increase the effectiveness of system researches and the learning process, to formulate new scientific hypotheses, to create systematic descriptions of mental phenomena",43 (Ganzen, 1984). According to V. Barabanshchykov, “... a systematic approach allows to define the research problem most precisely and to outline its solution strategy; it focuses the researcher on the study of the psyche as a differentiated unit, revealing the diversity of its connections and plans, levels and dimensions; it provides the creation of an extremely wide multidimensional picture of mental phenomena"44 (Barabanshchikov, 1997).

The main subjects of moral and psychological support in the State Border Guard Service are: the State Border Guard Service administrative staff, border guard divisions, departments of the border guard inspectors, support units, military chaplains, integrity inspectors, military collective groups (officers' meetings), freelance groups of internal communications.

We should analyze the measures taken by the subjects of moral and psychological support for maintaining the mental health of the border guards in special and/or extreme conditions of their professional activity in details.

Diagnostic measures include:

- the use of diagnostic tools, observation methods, surveys, expert assessment, etc.;

- analysis of the received information, interpretation of the diagnosis results;

43 Ganzen, V. A. (1984). Sistemnyye opisaniya v psikhologii [System descriptions in psychology]. Leningrad: LGU [in Russian].

${ }_{44}$ Barabanshchikov, V. A. (1997.). Printsip sistemnosti v psikhologicheskoy kontseptsii B. F. Lomova [The principle of consistency in the psychological concept of B. F. Lomov]. Psikhol. zhurn [Psychological Journal], T. 18, 1. P. 3-9 [in Russian]. 


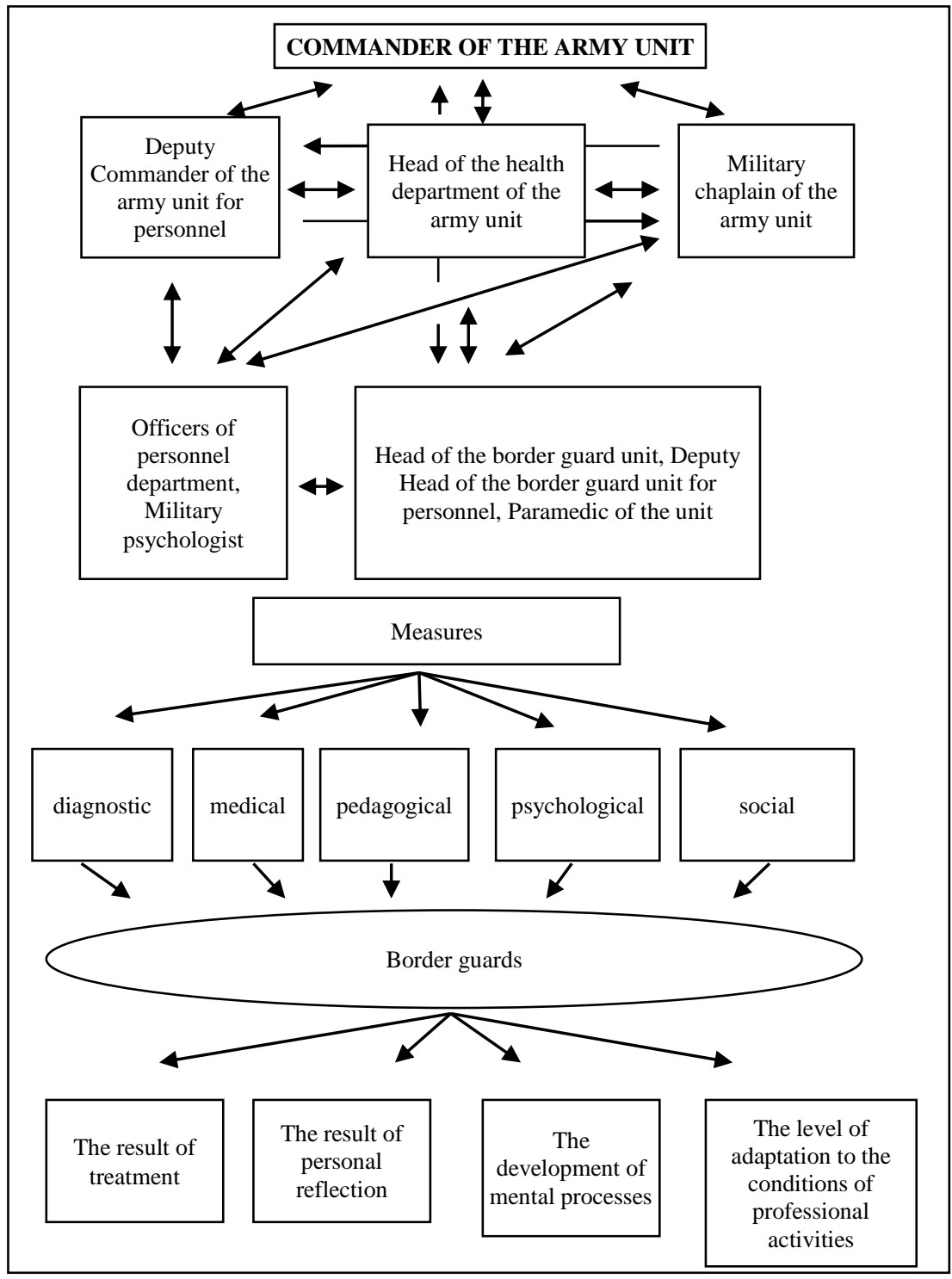

Fig. 1. The prognostic model of the interaction of the subjects of moral and psychological support for maintaining the mental health of the border guards in special and/or extreme conditions of their professional activity 
- determining the nature of the problem concerning the mental state of the military man;

- determining the most effective method of psychological assistance.

Medical measures include:

- medical examination of the border guards with mental health problems;

- carrying out preventive and rehabilitation measures, consultations;

- diagnosis and treatment of mental disorders;

- ensuring all types of compulsory medical measures;

- carrying out medical treatment together with a set of rehabilitation measures to re-socialize the border guards;

- active supervision, control of ambulatory treatment for the prevention of exacerbation of the disease, subject to the principle of voluntariness in the medical care provision;

- conducting preliminary and periodic psychiatric examinations;

- medical examination of recruits.

Pedagogical measures include:

- conducting classes and training with military personnel on improving their professional level;

- conducting talks and briefings on humanitarian themes;

- moral education of military men. In the basis of this process, there is an aspiration for the highest human values: the humanistic ideals of harmony, charity, truth, justice; predominance of altruistic motives, willingness to waive one's own interests for the sake of other people's ones.

Psychological measures are planned on the basis of diagnostic results and involve purposeful interaction with the military man to assist him in solving his psychological problems. The main forms of the work are the use of elements of cognitive-behavioral and physical therapy as well as psychological counseling and psychological support. Psychological support includes:

- regular observation of the behavior and service activities of military personnel by the psychologist, control over the implementation of the psychologist's recommendations;

- briefing, teaching the close social environment of the military man (commanders, comrades, family members) the necessary features 
of behaving with him, the methods and forms of providing psychological support, and monitoring the implementation of these recommendations;

- carrying out additional psychological consultations if it is necessary. When providing psychological help, both individual and group forms of work are provided.

Social measures include:

- development of culture and spirituality of the border guards;

- military and patriotic education of the border guards;

- conducting creative competitions, festivals and other events;

- organization of work on the implementation of social and legal guarantees of social protection of military personnel and their family members.

This list of activities is not complete and will be further elaborated.

Therefore, the introduction of the proposed prognostic model in the State Border Guard Service of Ukraine, in our opinion, will not only provide the maintenance of the mental health of the border guards in special and/or extreme conditions of professional activity, but also promote their professional and psychological development.

\section{CONCLUSION}

We should ascertain that, unlike foreign science (L. Hourani, J. Morgan, S. Tueller, M. Lane and other scientists), the topic of psychological activity of the military chaplains concerning the maintenance of military personnel's mental health is only beginning to be studied in the Ukrainian psychology, although, in the context of the cooperation between the Ukrainian church and military institutions, the problem was analyzed by such scientists as: V. Bondarenko, M. Vasiv, L. Vladychenko, S. Zdioruk, V. Yelenskyi, Y. Kalnysh, S. Lysenko, Y. Reshetnikov, S. Somin, O. Utkin and others. Some issues of pastoral care in the system of maintaining the mental health and upbringing of believing military personnel were studied by: A. Afanasiev, V. Dibrova, P. Kostiuk, R. Kohanchuk, M. Morozov, O. Melnyk. The works, which outline approaches to determining the directions, forms and methods of the clergy activity in the Armed Forces of Ukraine and of other states, are of considerable interest 
(O. Varnashova, L. Vygovskyi, A. Zhalovaha, E. Zabzaliuk, S. Semenov, T. Thorzhevska).

The essence of pastoral activities of military chaplains in the work with border guards can be reflected in:

- education of highly patriotic feelings and fighting spirit on the basis of the moral and spiritual potential of the religious and cultural heritage of the Ukrainian people;

- assistance to the military personnel in the development of their personal and collective moral traits and qualities: brotherhood, courage, bravery, responsibility, moderation, sacrifice, discipline, prudence;

- participation in the rehabilitation of the military personnel which need psychological assistance, since the ordinary military man may not always want to share the problems, which are of great concern for them, with a unit commander or a military psychologist.

The effective problem resolving concerning the active involvement of the military chaplains in maintaining the mental health of the border guards will contribute to the implementation of the Government-approved Program (July 12, 2017 № 475-r) of the State Target Program for physical, medical, and psychological rehabilitation and social and professional re-adaptation of anti-terrorist operation participants who took part in the implementation of measures for national security and defense, repulsion and deterrence of armed aggression of the Russian Federation in Donetsk and Luhansk regions, providing their implementation for the period up to 2022 .

\section{SUMMARY}

The article deals with the problems of maintaining the mental health of the border guards in special and/or extreme conditions of their professional activity with involvement of the military chaplains at the present stage of development of the State Border Guard Service of Ukraine and proposals for its improvement. The deviant behavior of the military personnel in the form of suicidal and addictive behavior has been analyzed. The possibility of preventing the deviant behavior of the border guards in special and/or extreme conditions of their professional activity by means of the pastoral activity of the military chaplains has been considered. The prognostic model of the interaction of the moral and psychological support subjects in maintaining the 
mental health of the border guards in the special and/or extreme conditions of their professional activity is proposed.

\section{REFERENCES}

1. Aleshchenko, V. I., Safin O. D., Potapchuk Ye. M. (2007). Orhanizatsiia zabezpechennia zberezhennia psykhichnoho zdorovia viiskovosluzhbovtsiv [Organization of maintenance of mental health of military personnel]. Kyiv [in Ukrainian].

2. Barabanshchikov, V. A. (1997). Printsip sistemnosti v psikhologicheskoy kontseptsii B. F. Lomova [The principle of consistency in the psychological concept of B. F. Lomov]. Psikhol. zhurn [Psychological Journal], T. 18, 1. P. 3-9 [in Russian].

3. Busel, V. T. (Red). (2005). Velykyi tlumachnyi slovnyk suchasno ukrainskoi movy [A great explanatory dictionary of modern Ukrainian]. Kyiv: Perun [in Ukrainian].

4. Derzhavna sluzhba statystyky Ukraiiny [State Statistics Service of Ukraine]. (2018). Lyst [Letter]. Retrieved from: ps://dostup.pravda.com.ua/request/34337/response/76881/attach/2/15.2 $\% 2020 \% 20770 . p d f$ [in Ukrainian].

5. Durkheim, E. (1994). Samoubiystvo: Sotsiologicheskiy etyud [Suicide: A sociological study]. Moskva: Mysl [in Russian].

6. Filonenko, M. M. (2015). Psykholohiia osobystisnoho stanovlennia maibutnoho likaria [Psychology of personality formation of the future doctor]. Kyiv: Tsentr uchbovoii literatury [in Ukrainian].

7. Ganzen, V. A. (1984). Sistemnyye opisaniya $v$ psikhologii [System descriptions in psychology]. Leningrad: LGU [in Russian].

8. Grishin, Ye. A. (Red). (1994). Sovremennyy slovar inostrannykh slov [Modern dictionary of foreign words]. Sankt Peterburg: Duyet [in Russian].

9. Gubskiy, Ye. F. (Red). (1997). Filosofskiy entsiklopedicheskiy slovar [Philosophical Encyclopedic Dictionary]. Moskva: INFRA [in Russian].

10. Kalenychenko, T., Kokhanchuk, R. (2017). Buty poruch. Osnovy viiskovoho kapelanstva dlia viiskovykh $i$ volonteriv [To be near. Basics of military chaplaincy for military personnel and volunteers]. (2-e vydannia). Kyiv: Makhanaym Prynt [in Ukrainian] [in Ukrainian]. 
11. Kalenychenko, T. A. (2018). Relihiina skladova suspilnopolitychnoho konfliktu kintsia 2013-2017 rr. v Ukraiini [The religious component of the socio-political conflict of the end of 2013-2017 in Ukraine]. (Dys. kand. filosof. nauk). Nats. ped. un-t. im. M. P. Drahomanova, Kyiv [in Ukrainian].

12. Karayani, A. G. (2006). Prikladnaya voyennaya psikhologiya [Applied Military Psychology]. Sankt-Peterburg: Piter [in Russian].

13. Kikalishvili, M. (2001). Deviantna povedinka: poniattia ta oznaky [Deviant behavior: concepts and features]. Visnyk Akademiii advokatury Ukraiiny [Bulletin of the Academy of Advocacy of Ukraine], 3(22), 109-122. Retrieved from: irbis-nbuv.gov.ua/cgibin/irbis_nbuv > cgiirbis_64 > vaau_2011_3_17 [in Ukrainian].

14. Kon, I. S. (1967). Sotsiologiya lichnosti [Sociology of personality]. Moskva: Politizdat [in Russian].

15. Kon, I. S. (1997). Vkus zapretnogo ploda [The taste of the forbidden fruit]. Moskva: Semya i shkola [in Russian].

16. Levina, I. A. (2001). Profesiina diialnist uchytelia z formuvannia piznavalnoi samostiinosti pidlitkiv zasobamy modeliuvannia [Teacher's professional activity on forming of teenagers' cognitive independence by means of modeling]. (Dys. kand. ped. nauk). Pivdennoukr. derzh. ped. un-t im. K. D. Ushynskoho, Odesa [in Ukrainian].

17. Lichko, A. Ye. (1983). Eti trudnyye podrostki [These difficult teens]. Moskva: Meditsina [in Russian].

18. Melnyk, S. V. (2006). Modeliuvannia diialnosti innovatsiinoho navchalnoho zakladu - Shkoly spryiannia zdoroviu [Modeling the activities of an innovative educational institution - Schools for health promotion]. Ridna shkola [Home School], 4, 25-29 [in Ukrainian].

19. Melnyk, Ya. I. (2016). Psykhoprofilaktyka deviantnoi povedinky viiskovosluzhbovtsiv $v$ osoblyvykh umovakh diialnosti [Psychoprophylaxis of deviant behavior of military personnel in special conditions of activity]. (Dys. kand. psykhol. nauk). Natsionalna akademiia Derzhavnoii prykordonnoii sluzhby im. B. Khmelnytskoho [in Ukrainian].

20. Meshcheryakova, B. G., Zinchenko, V. P. (Red). (1983) Psikhologicheskiy slovar [Psychological Dictionary]. Moskva: AST [in Russian]. 
21. Mykhailiuk, I. R. (2001). Pedahohichni umovy ta model formuvannia hotovnosti do pedahohichnoi diialnosti mahistriv tekhnichnoho spriamuvannia [Pedagogical conditions and model of forming the readiness for pedagogical activity of masters of technical direction]. Visnyk Natsionalnoi akademii Derzhavnoi prykordonnoi sluzhby Ukrainy [Bulletin of the National Academy of the State Border Guard Service of Ukraine], 3, 21-27 [in Ukrainian].

22. Moskalets, V. P. (2004). Psykholohiia relihii [Psychology of religion] : posibnyk. Kyiv: Akademvydav [in Ukrainian].

23. Nepipenko, L. P. (2017). Problemy ta perspektyvy instytualizatsii viiskovoho dukhovenstva (kapelanskoi sluzhby) $v$ Ukraini [Problems and Prospects of Institutionalization of the Military Clergy (Chaplaincy Service) in Ukraine], Naukove zabezpechennia sluzhbovo-boiovoi diialnosti Natsionalnoi hvardii Ukrainy [Scientific Support for Service and Combat Activity of the National Guard of Ukraine], zb. materialiv dop. uchasn. VIII nauk.-prakt. konf. Kharkiv: NANHU. Retrieved from: http://nangu.edu.ua/wp-content/ uploads/2017/04/3бірник-тез-2017_секція-4.pdf [in Ukrainian].

24. Ovcharova, L., Movchan, A. (2018). Technologies of social work with persons easy to suicide Reporter of the priazovskyi State technical University Section: Socially-humanitarian sciences and public administration, 1, 119-122 [in English]

25. Pobirchenko, N. A. (Red). (2007). Psykholohichnyi slovnyk [Psychological Dictionary]. Kyiv: Naukovyi svit [in Ukrainian].

26. Poplavska, S. D. (2009). Model formuvannia hotovnosti studentiv medychnykh koledzhiv do komunikatyvnoi vzaiemodii $u$ profesiini diialnosti [Model of forming the readiness of students of medical colleges for communicative interaction in the professional activity]. Visnyk Zhytomyrskoho DU im. I. Franka [Bulletin of I. Franko Zhytomyr State University], 46, 92-96 [in Ukrainian].

27. Potapchuk, Ye. M. (2004) Sotsialno-psykholohichni osnovy zberezhennia psykhichnoho zdorovia viiskovosluzhbovtsiv [Sociopsychological bases of maintaining mental health of military personnel]. (Dys. d-ra psykhol. nauk) Natsionalna akademiia Derzhavnoi prykordonnoi sluzhby im. B. Khmelnytskoho, Khmelnytskyi [in Ukrainian].

28. Predko, O. I. (2005). Psykholohiia relihii: istoriia, teoriia, relihiieznavchi vymiry [Psychology of Religion: History, Theory, 
Religious Dimensions]. Kyiv: Tsentr navchalnoi literatury [in Ukrainian].

29. Prokhorov, A. M. (Red). (1991). Bolshoy entsiklopedicheskiy slovar [Great Encyclopedic Dictionary]. Moskva: Sov. Entsiklopediya [in Russian].

30. Reber, A. (Red). (2003). Bolshoy tolkovyy psikhologicheskiy slovar [Great explanatory psychological dictionary]. (T. 1 (A-O)). Moskva: AST [in Russian].

31. Romanyshyn, A. M. (Red). (2017). Profilaktyka vidkhylnoi povedinky $u$ viiskovosluzhbovtsiv [Prevention of deviant behavior of military personnel]. Lviv: NASV [in Ukrainian].

32. Samohubstva v armii [Suicide in the Army]. (2018, liutyi 26). Ukrainska Pravda [The Ukrainian Truth]. Retrieved from: https://www.pravda.com.ua/news/2018/02/26/7172855 [in Ukrainian].

33. Shynkaruk, V. I. (Red). (1986). Filosofskyi slovnyk [Philosophical Dictionary] Kyiv: Holovna redaktsiia URE [in Ukrainian].

34. Spirina, T. P. (2008). Model formuvannia profesiinoi kultury maibutnikh sotsialnykh pedahohiv [Model of professional culture formation of future social educators]. Visnyk Prykarpatskoho universytetu : pedahohika [Bulletin of the Carpathian University : Pedagogy], 21, 278-291 [in Ukrainian].

35. Vlada znaie ne vse... [The authorities do not know everything...] OBOZREVATEL.ua. [OBSERVER.ua] Retrieved from: https://www.obozrevatel.com/ukr/crime/statistika-zanizhena-veteranato-rozpoviv-pro-vbivstva-i-suitsidi-v-armii.htm [in Ukrainian].

36. Vsesvitnia orhanizatsiia okhorony zdorovia [World Health Organization]. Retrieved from: https://www.who.int/ru/news-room/factsheets/detail/mental-health-strengthening-our-response [in Ukrainian].

\section{Information about the author: Artem Makovskyi,}

Postgraduate student of the Military Postgraduate School National Academy of the State Border Guard Service of Ukraine named after Bohdan Khmelnytskyi 46, Shevchenko str., Khmelnytskyi, 29003, Ukraine ORCID ID: orcid.org/0000-0003-2903-3351 E-mail: makovski200844@gmail.com 


\section{THEORETICAL AND METHODOLOGICAL APPROACHES TO OPERATIONALIZATION OF THE CONCEPT OF "PERSONAL RESOURCES" IN PSYCHOLOGY}

\section{Anatolii Yakymchuk}

\section{INTRODUCTION}

The psychological essence of a human being is a living and, in its higher manifestations, conscious subjective intention. It is expressed in the desire to reproduce and realize own's own psychic resource to the maximum extent, to develop one's own psyche to the possible limits of perfection, to maintain this level as long as possible, thereby providing the formation and development of personal structures with their "relational" social essence and individuality, that chiefly manifests itself within the space of the unique Self.

Throughout the long development of psychological science, the scientists have sought to understand what is at the heart of human viability, overcoming various difficulties, achieving success in various spheres of life such as gaming, educational, labour, household, etc. Psychic resources have been considered as a source of a person's internal strength that allows the individual to cope with unusual, nonstandard situations, as well as to achieve significant life successes in everyday life.

The intensive study of the psychic resource in recent decades is directly related to the successes in the field of personality research, with broad-scale development being carried out in psychology. Today, the leading theories and concepts of personality, each of which claims to be unique and significant, have already taken shape. It becomes clear that the level of human psychic potential is determined by the conditions that surround and guide its development.

\section{Phenomenology of the concept "personal resources" in psychological discourse}

Scientific interest to the phenomenon of human "resources" is determined by their important role in ensuring human life-sustaining 
activity in difficult, sometimes extreme living conditions, including difficult situations of professional activity of persons throughout all stages of life. The subject of human resources covers a wide range of topical problems of its resource's provision as an actor, including: potentials and resources of adaptation to difficult conditions and circumstances of life and work; vital capacity resources and the dynamics of their changes over the course of their lives and professionalization; resources of professional formation and efficiency of the actors of labour; resources for overcoming professional and personal crises; resources to counteract professional and personal deformities and maintain occupational health; dynamics and "weight" of resources at different stages of professionalization; conditionality of human resources by external and internal determinants of human activity as an actor; technologies for preserving occupational health resources.

As a result of the efforts of several generations of psychologists, the problem of the human psychic resource has gradually developed into an independent scientific direction with defined categoricalconceptual apparatus and system of constructs, formed ideas of the determinants and the possibilities of its use. The interpretation of psychic resources was determined by the original methodological positions of the authors, who turn to the consideration of personality and related problems.

The representatives of different scientific schools and fields (B. H. Ananiev, L. I. Bozhovych, A. V. Brushlynskyi, L. S. Vyhotskyi, O. M. Leontiev, D. O. Leontiev, A. V. Petrovskyi, S. L. Rubinshtein, V. M. Miasyshchev, Z. Freud, A. Adler, K. Jung, G. Allport, A. Maslow, K. Rogers and others) tried to represent, within their own scientific constructs, the formation of scientific approaches to understanding personal resource which reflects the stages of finding answers to the question of the psychological nature of the phenomenon of personality.

The resource range of problems of modern psychology have their origins in the consideration of adaptive capabilities of an individual which are in demand under tense, difficult, stressful and extreme types of situations. As a process of adapting to certain life circumstances, the 
adaptation process can be successful with the involvement of certain life resources by the individual ${ }^{1}$.

The basis for the next step in the scientific research of the resource range of problems was the understanding that has emerged in psychology of the fact that human forces can be considered not only in terms of human interaction with the environment, but also in terms of mechanisms of functioning. Psychological protections, which can be considered as a psychological instrumentarium that has its own advantages and limitations, the preservation and filling of internal resources of the individual have received a detailed study in psychology.

Understanding potential as an opportunity that, under certain conditions, can be transformed into a psychological resource for solving any pressing tasks is the basis for the differences between these psychological formations. This condition can most often be represented by an activity. The concepts of "psychological resource" and "personal potential" have recently been suggested with the possibility of using the concept of "social and psychological capital of the individual", which is characterized as a dynamic system of relations of the individual, which is a resource that facilitates the achievement of various goals by the individual ${ }^{2}$. In actual fact, this concept is identical to the concept of "psychological resource".

The concept of "psychological resource" is characterized by a significant conceptual variation element, which reflects the lack of formation of its interpretative base. In the general sense, the word "resource" can be considered as a source of human strength, as a set of values, reserves, opportunities that allow performing daily activities, coping with difficult life situations, solving the problem of "vitality" of the individual ${ }^{3}$.

1 Kokun O. M. Optymizatsiia adaptatsiinykh mozhlyvostei liudyny u pcykhofiziolohichnomu zabezpechenni diialnosti: dys. ... d-ra pcykhol. nauk. Instytut pcykholohii im. H. S. Koctiuka APN Ukrainy. K., 2004. 426 s.

${ }^{2}$ Tatarko A. N. Sotsialno-psikhologicheskii kapstal lschnocts v polskulturnom obshchestve: diss. d-ra psikhol. n. M., 2014. 403 s.

${ }^{3}$ Petrovskiy V. A. Lichnost v psikholohii: paradigma subiektnosti. M.: Izd-vo Voronezhskogo un-ta, 1996. $232 \mathrm{~s}$. 
A sufficiently large field of psychological phenomena of the individual, belonging to different spheres of human organization and functioning was considered as a psychological resources. All psychic resources of the individual are conditionally divided by their origin into external and internal ones. External individuals' resources, taking the form of social or socio-psychological support, assume that they have the ability to use this support. Internal resources are the persons' own personal potential, which is actualized by means of certain psychological instrumentarium ${ }^{4}$.

A number of works distinguished that the individual's internal resources have coping-resources due to great opportunities for their conscious, volitional, purposeful management. As a resource management tool, the coping-resource has a certain specialization that allows actualizing the internal resources of the individual taking into account the specific features of the situation. In this case, the possibility of transition from situational to personal and from functional to meaningful consideration of human psychic resources is indicated. Additional resources are needed for the individual and society to overcome the crisis in times of uncertainty growth. The resources include those social and personal qualities that can either help or prevent the individual from living and developing productively.

L. S. Vyhotskyi regarded the human body, the human personality and the human intellect as an integral whole, consisting of certain functions and elements withing in a complex structure and in complex relationships with each other. He came very close to understanding the phenomenon of creativity, seeking to explain the consequence of origin of "something not existing before". To the full extent, this "something" can be understood as psychological resources.

${ }^{4}$ Safin O. D., Baranov O. M. Osnovni rezultaty diahnostychnoho doslidzhennia osnovnykh komponentiv osobystisnoho potentsialu maibutnikh fakhivtsiv inozemnoi movy. Visnyk Viiskovoho instytutu KNU imeni Tarasa Shevchenka, Seriia «Psykholohiia», 2009. № 23. S. 77-81.

5 Kazanzhy M. Y. Osobystisni resurcy podolannia pcykholohichnoi kryzy. Visnyk Natsionalnoi akademii Derzhavnoi prykordonnoi sluzhby Ukrainy. Seriia: Psykholohiia. 2015. Vyp. 1. Rezhym dostupu: http://nbuv.gov.ua/UJRN/ Vnadpn_2015_1_6 
The origins of the resource approach to solving a wide range of psychological problems of human life support are contained in the works of S. L. Rubinstein and B. H. Ananiev, which cover at least two conceptual aspects of the phenomenon of "resources": first, the systemic nature of the resources, understood as a manifestation of the complex interaction of human capabilities, potencies and internal forces throughout life; secondly, the dependence of the formation and manifestation of reserves and human resources on the conditions of the outside world and the activity of the individual as an actor of life.

The following ideas of B. H. Ananiev are productive in the light of modern psychological researches from the standpoint of the resource approach to human capabilities (resources, reserves, potencies, internal human forces): extraction of different classes of human development potentials which are denoted by the concepts of "giftedness", "ability", "employability", "viability"; the idea of the dual dependence of manifestation of reserves and resources of the individual: on the living conditions of the outside world and on the structure of the individual's personality; the assumption on the possibility to create some common model of reserves and resources of the individual in the future; emphasizing the special importance of a comprehensive study of different potentials and tendencies of the activity actors ${ }^{6}$.

The concept of resources has different interpretations. The term itself is borrowed from the French language (ressourse) and literally means "ancillary (technical, energy, information) tool". The content of the concept "resource" is multidisciplinary, so the full characterization of "resource" is possible only as a synthesis of the perspectives of various scientific fields of humanitarian knowledge. The concept of a resource is not clearly defined even from an intra-disciplinary psychological standpoint. There are different interpretations and classifications of "resources" among scientific schools and scolars, as well as different concepts of development, actualization and depletion of resources. The concept of "resource" is used by some authors in Soviet and Ukrainian psychology as a synonym for the concept of

\footnotetext{
${ }^{6}$ Ananev B. G. Chelovek kak predmet poznanyia. L.: Izd-vo LGU, 2009. 324 s.
} 
"potential", and the foreign research tradition understands the resource as a factor of protection? ${ }^{7}$.

The concept of "resource" is most often characterized in psychology as a certain stock of life opportunities that can be used by the individual as a means of personal development, selfdetermination, implementation of activities, choosing life strategies, life options, etc. The concept of "personality potential" is close to the aforementioned concept in its meaning, which, according to D. O. Leontiev, is an integral characteristic of the level of personal maturity, the main indicator and form of manifestation of which is represented by self-determination, that is, carrying out activities in relative freedom from external and internal conditions (from biological prerequisites, from needs, character and other stable psychological parameters $)^{8}$.

Human resources are usually talked about when they mean human potential in a society, organization, the state, etc. The term of "human resources" in the organizational and psychological context reflects the notion that people are an important resource of an organization, among others (material, financial, informational, etc.), which determines its competitiveness. In a broad sense, human resources are a set of qualities and means that the individual has at his disposal and that can be used by him for self-realization in different life contexts. The concept of a resource is used to refer to different levels of human life regulation: physical resources of the body, psychological, personal, social, spiritual, material, economic resources.

\section{The semantic field of the concept "personal resource" in various scientific schools and trends}

In theories of overcoming stress, "resource" is often regarded as a functional (psychological, physiological, professional, etc.) potential, which provides a stable level of realization of human activity and

7 Manokha I. P. Psykholohiia potentsialu indyvidualnoho buttia liudyny: ontolohichno oriientovanyi pidkhid: dys.. d-ra psykhol. n. K., 2002. 373 s.

${ }^{8}$ Leontoev D. A. Vvedeniye: lichnoctyi potentsial kak obiekt izucheniya. Lychnostnyi potentsial: struktura y diahnostika. M.: Smysl, 2011. S. 5-11. 
achievement of the set parameters for a certain period of time ${ }^{9}$. Despite often use of the term of "resources" and the recognition of the importance of resource support of life, including productive professional activity of the individual the concept of the resource as a psychological category is not enough developed due to the fact that the individual as a complex system has different levels of organization with certain resources inherent to each of them.

In general, the psychology of stress and its overcoming understands resources as the physical and spiritual capabilities of the individual the mobilization of which ensures the implementation of programs and methods (strategies) of behaviour aimed at preventing or reducing stress. In the broad interpretation of the psychological resources they are included in the concept of personal and human potential, as well as in the description of life strategies. In a narrower interpretation, the resources are seen as opportunities and means of coping-behaviour, overcoming stress, as elements of self-organization, self-regulation of activity and behaviour ${ }^{10}$. The problem of resources of coping-behaviour, according to L. I. Antsiferova, V. O. Bodrov and other scientists has not yet received proper consideration in psychology, since the corresponding system of concepts and theories of the development of these resources in the structure of personality has not been sufficiently formed.

Theoretical analysis of modern ideas on the dynamics of stress syndromes development indicates the possibility of counteracting them in the context of the concept of multifaceted and multilevel organization of human resources. Stress is ensured from the standpoint of the resource concept through the activation of human resources belonging to different levels of psychic regulation. "Resources" as a psychological category are considered in various aspects: as strategies of life (K. O. Abulkhanova, L. I. Antsiferova, A. A. Kronyk); as opportunities and means of overcoming stress i.e. resources of the one who mastered it (V. O. Bodrov, R. Lazarus, S. Hobfall,

9 Timchenko A. V. Professionalnyi stres rabotnikov OVD Ukrainy (kontseptualizatsyia, prohnozirovaniya, diahnostika i korrektsiya): diss. ... d-ra psikhol. nauk. Kharkov: NUVD, 2003. 427 s.

${ }^{10}$ Korolchuk V. M. Psykholohiia stresostiikosti osobystosti: dyc. kand. psykhol. nauk. Instytut psykholohii im. H. S. Koctiuka APN Ukrainy. K., 2009. 513 s. 
S. O. Khazova); as mechanisms of self-regulation and regulation of activity and behaviour (T. L. Kriukova, L. H. Dykaia, V. I. Morosanova, V. O. Tolochek, etc.); as mechanisms of psychic regulation of activity and behaviour (L. H. Dykaia, Ye. Yu. Kozhevnykov); as a special organization of psychic properties and as a structure of their links (V. M. Druzhynin, D. O. Leontiev, M. A. Kholodnaia); as resource states (O. O. Prokhorov, V. V. Kozlov).

Some authors define resources as the main factors of ability to handle stress, resistance of the individual to stress. Stress resistance resources mean internal and external variables that contribute to maintaining productivity, psycho-physical health and social adaptation in stressful situations. These are emotional, motivational-conative, cognitive, value-semantic and behavioral "tools" (constructs) of psychological regulation that a person actualizes for adaptation to stressful factors and stressful episodes of life.

According to scientists one's own, individual psychological human resources include both individual properties of the personality, values, goals, strategies of behaviour, and psychological mechanisms of self-regulation, complex dynamic relationships within the system of "human-world".

Given the diversity of concepts as well as those aspects of the resources under consideration, it is important to define the key criteria for the "resource" category. There is also no consensus on this issue. From the standpoint of the subject paradigm, resources can be determined by the effects of the manifestation of performance of the actor of activity. A key criterion for human resources as an actor are the effects of their regulatory functions. Thus, D. O. Leontiev means those individual features by the resources, depending on which the tasks of mobilization and adaptation to a stressful situation, its overcoming are solved easier or, conversely, more difficult. Therewith, the author proceeds from the idea of the bipolarity of resources, according to which some resources may block overcoming. V. O. Tolochek also associates resources with the positive effects of psychological regulation and gives the following definition: "Resources are psychic properties that are firmly linked in the mental experience of the individual to the positive effect, the 
presence of tangible benefits and they can be used to improve the efficiency of life" $"$.

On the basis of theoretical analysis, we can distinguish the following key methodological foundations of subject-resource approach to understanding the interaction and interrelation of resources and human activity as an actor of life-sustaining activity, including labour activity: the actor and resources are the integrated system of manifestation of human activity in the process of implementation of various activities, including scntubstantive work (labour); resources are subjective qualities that ensure the achievement of the goal of activity and psychological well-being of the individual (job satisfaction, self-realization, preservation of occupational health); actualized resources change the quality of life of the individual in the world objective (material) world and psychologic world (subjective picture of the world, the world of experiences, values, life philosophy), in social, spiritual, cultural spaces; the main functions of subjective resources are the realization of goals, potential opportunities, personal aspirations in accordance with the objective conditions and requirements of the activity and environment.

The psychological resources of the actor of activity are the constructs of psychological regulation of different levels of human organization. Resource development has a complex determination: it depends on external (extra-subjective) and internal (intra- and intersubjective) factors; psychological resources are dynamic (there are periods of their development, stagnation, involution, complex patterns of losses and gains); depending on the actor activity, the resources are attracted, adjusted and developed according to the requirements of professional activity and situational conditions, as well as depending on the life philosophy and attitudes.

Differences in the understanding of the phenomenon of "resource" give rise to many approaches to the classification of human resources as an active actor of life. According to the subject-activity paradigm, resources are classified according to several criteria: according to the regulation of human activity: physical, psychic, personal, social,

11 Tolochek V. A. Professionalnaia uspeshnost: ot sposobnostei k resursam (dopolniaiushchye paradyhmy). Psikholohyia. Zhurnal Vysshei shkoly ekonomiki. 2009. T.6. № 3. S. 27-61. 
spiritual, existential, material; according to the purposeful function: the resources of adaptation (vitality, survival), the resources of change and development, the resources of sustainability i.e. the preservation of human activity for the implementation of the desired parameters of vital activity for a certain period of time (V. O. Bodrov, L. H. Dykaia, Ye. P. Ilin, O. H. Maklakov and others); according to the level of psychic organization: the resources of the individual, actor (subject), personality and individuality (B. H. Ananiev); according to the origin: natural (born), acquired, restored, artificially created; according to the content: energy, time, information, space-environmental (V. A. Hanzen); according to the space-time mode: subjective, situational and supersituational resources (V. A. Petrovskyi); according to the relation to the actor (subject): intrasubjective i.e. inherent qualities to the certain individuals; intersubjective i.e. the systemic qualities that arise when interacting and performing joint group activities; nonsubjective i.e. the qualities of the two kinds arising in the process of "live" interaction (procedural) and broadcasted ("subjectified") by the media of culture (V. A. Tolochek).

Foreign authors often distinguish four classes of resources: physiological (health, absence of physical defects, physical endurance, etc.); psychological traits (self-esteem, confidence, sense of control, ability to self-disclosure, etc.); cognitive properties (ability to learn, persuasion, ability to structure information, etc.); social support and financial well-being, financial freedom.

S. Hobfall classifies human resources according to several criteria: by relation to the individual: by resources "Ego"-concept (internal, external); by localization of the source and relation to other resources: objective, personal, resources of states or conditions, material and energy resources; by value for survival: primary, secondary, tertiary. According to the concept of conservation of resources by S. Hobfall, people seek to preserve, protect, replenish and reserve personal resources. The feeling of psychological threat, stress syndromes is first and foremost related to the sense of loss of resources or the difficulty of their restoration. Therefore, it is important to uncover the patterns of resources loss and restoration, theoretical and empirical studies of human resource provision at different stages of one's life and in various spheres of one's life-sustaining activity, 
including the study of the laws of resource provision of the actors of labour $^{12}$.

Studying only the psychological mechanisms of development and expenditure of human psychic resources does not allow to make an adequate picture of the development of this phenomenon. There is an urgent need for its meaningful research. The researches on the subject have been conducted by: Yu. M. Zabrodin and T. S. Kabachenko on psychology of human resources management; Yu. V. Kuzmenko on the psychological resources of the individual adaptation to the conditions of increased risk of natural disasters; O. V. Neumoieva, O. Ye. Rohova on the features of loneliness as a resource of personality development in adolescence; O. Yu. Kozhevnikova on personal resources of overcoming the situation of socio-economic deprivation; O. I. Babych on the psychic resources of overcoming the professional burnout syndrome of teachers; M. V. Rahulina on authenticity as a psychological resource of self-organization of the individual. The works by H. A. Berulava, O. H. Vlasova, I .O. Vasylieva, D. O. Leontiev and others researched the issues of lifesustaining activity success; self-regulation; psychological well-being; self-realization; self-development; self-actualization; overcoming uncertainty; bringing the goals to their realization; preservation of stability and integrity of the individual as components of human vital resources, etc.

Scientists have identified three sub-structures of personal potential that correspond to three functions of self-regulation: the function of orientation or self-determination; function of realization related to the organization of purposeful activity; function of preservation, which ensures the preservation of psychic stability against the backdrop of adverse circumstances. Each of these components is represented differently in theoretical constructs and models, as well as in methodological instrumentarium, which is associated with the complexity of the development of individual aspects of personal potential and the unequal demand for them from practice.

${ }^{12}$ Hobfoll S. E. Conservation of resources: A new attempt at conceptualizing stress. American Psychologist. 1999. Vol. 44(3). P. 513-524. 
It has been proved that the individual receives external psychic resources through the social way of his or her existence. Social support and encouragement, fellow feeling, mutual assistance and other social phenomena are a significant factor in achieving the individual's vital well-being. Internal resources are associated with some of the inherent human resources that make it possible to overcome various stress factors and difficulties. Such internal factors are the cognitive abilities of the individual, his or her intellect, emotional resources, spiritual potential, some personality possibilities, etc.

A special place among the human psychic resources is taken by the so-called personal resources i.e. a complex formation, which combines a significant part of the system of psychic support and selfsufficiency of the individual. At the organizational level, personal resources integrate the structural components of the individual with different levels of complexity that determine his or her success in educational, professional and personal fields. Recognizing the importance of human psychic resources, modern psychology has not yet paid sufficient attention to the study of conceptions about them concerning actors who are at different stages of ontogeny. At the same time, it has already been proven that conceptions play a significant role in the organization of human psychic life. Being the subjective reflection of objective reality in the mind of the individual, they are at the heart of constructing the image of the world and defining the person's place in it, planning one's own activity, organizing the response to events that are happening, etc.

As K. R. Kapiev states, the conception of personal resource can be regarded as some formed system of concepts, attitudes and experiences of the individual to this psychic formation. The individual's dominant use of a particular structure of personal resources is reflected in his or her success. Thus, cognitive and intellectual resources determine the following characteristics of the individual: intelligent, advanced, knowledgeable, experienced, deep-read, competent, attentive, judicious, prepared, erudite, authoritative, comprehensive, talented. The presence of resources of emotional and volitional self-regulation allows the individual to be persistent, courageous, strong, confident, employable, patient, calm, purposeful, determined, sustained, collected, diligent, etc. The use of axiological resources of the individual is reflected in the following characteristics of the person: 
inspired, pure, strict, motivated, deep, responsible, dedicated, constant, proud, optimistic. Resources of social interaction allow the individual to be open, direct, pleasant, mobile, active, friendly, sociable, casual and more. With the help of broadcasting subjective parameters, it becomes possible to make real transformations not only in the perceptual, cognitive, emotional and volitional, but also in the personal spheres $^{13}$.

Consideration of personal resource contributed to the study of the ontogeny of personality development, i.e. the forms of individual and social development of the individual in the process of social adulthood, which has its own character, its levels of development, integrating all the resource possibilities and achievements. There is no doubt that each of the stages of personal development has its own characteristics, levels of development, conditions and factors that determine the specifics of its formation and functioning.

The general system of determinants of personal resource development gradually expanded and became more complicated: the number of its levels and dimensions increased, the variety of connections between causes, conditions, factors and preconditions increased. For a long time, personality studies have been located in the continuum of optimality (higher levels of development and achievement) - pessimality (crisis, regression or related to overcoming difficulties). This time, in the figurative expression of A. V. Brushlynskyi, was a period of renaissance of the concept of the study subject. Consideration of the resource of the individual has acquired a pronounced axiological emphasis in the context of the category of the study subject. The category of the subject began to be regarded as a systemic factor of the integrity of the individual and his or her life path. The concept of personality as a subject of life path allowed to consider not only the dependence of the individual on his or her life, but also the dependence of life on the psychic resources of the individual ${ }^{14}$.

13 Kapieva K. R. Psikhicheskiy resurs lichnosti: patterny y determinanty razvitiya. Nauchno-prakticheskiy zhurnal «Humanizatsiya obrazovaniya», 2015. № 3. S. 75-81.

${ }^{14}$ Hrinova O. M. Psykholohiia proektuvannia zhyttievoho shliakhu osobystistiu yunatskoho viku: dys.. d-ra psykhol. n. Natsionalnyi pedahohichnyi universytet imeni M. P. Drahomanova, K., 2018. 562 s. 
The unity of the views of scientists is that they recognize the diversity and multiplicity of human resources as the subject of life. N. Ye. Vodopianova has developed a subject-resource concept of counteracting occupational-personal deformities on the example of counteracting the professional burnout of labour actors on the basis of analytical generalization of resource theories and approaches. The main hypothesis and the idea of her subject-resource approach is that professional burnout is a systemic effect of the reduction and involution of resources of different levels of psychological regulation. From the standpoint of resource provision of the actor of labour, the intrasubjective cause of burnout is the involution of situational and positional resources and resources of activity-important qualities of the actor of professional activity: at the situational level of regulation it is a decrease in the activity of psychic self-regulation and coping behaviour of the actor (deficit of resources for self-regulation, self-identification, proactive management of professionally difficult situations); at the dispositional level of regulation, it is the involution of spiritual-moral, social-psychological resources as a consequence of the decline of cognitive-existential, cognitive-semantic, positive-setting activity of the actor of professional activity; at the professional-personal level, it is a shortage of competence resources i.e. activity-important qualities, abilities, skills, competences of the actor.

Potential, reserves and resources are different phenomena ${ }^{15}$. In the context of the subjective paradigm, potential is a set of internal possibilities that exist in a hidden form, in potentcy, and may manifest themselves under certain conditions. The actor's resources are any internal and external conditions, real and ideal objects, individual qualities, relationships, attitudes, values created and used by the actor to solve his or her own tasks and achieve significant goals. Resources can be actualized, accumulated, distributed, spent, reconstructed and restored due to subjective activity (activity of different levels of psychological regulation).

One of the key concepts of N. Ye. Vodopianova conception is a "resource base" that is understood as a complex structural-level

15 Hrimak L. P. Rezervy chelovecheckoi pcikhiki: Vvedenie v psikholohiyu aktivnosti. M.: Politizdat, 1989. 319 s. 
conglomerate of psychological resources available to the actor and involved by him or her to solve significant current tasks and achieve strategic goals of the activity. The resource base includes mechanisms of different levels and systems of regulation. The resource base for combating professional burnout is a three-dimensional space of resources for professional and personal development, resources for maintaining resistance to professional difficulties and resources for overcoming occupational difficulties. The resources to counteract professional burnout represent the available and "strategic" means and conditions for the realization of the desired interests and goals of the person as an actor in the subjective and dynamic aspect of professionalization of the actor of labour.

In accordance with the leading functions of psychological regulation of activity in psychology, the following classification of resources to counteract professional burnout is proposed.

1. Motivational and impulsive resources (purpose-motivated, selfdetermination resources) contribute to the awareness and promotion of goals, understanding of their personal significance, creating the basis for the adoption of the target vector. The acceptance of the goal occurs in the form, as it is perceived by the actor. The essential qualities of the human being as the actor of goal formation are manifested in the realization of what is valuable and meaningful, what he or she is experiencing, what he or she zests for, what he or she seeks, what he or she deems necessary, "right or wrong", and what he or she plans to $\mathrm{do}^{16}$. It is subjectively represented in feelings and thoughts: "I want I do not want", "obliged - not obliged", "obligatory - not obligatory", "what I want to do", "what I should do" and so on, that is, in aspirations and motives. Incentive function is performed by values and life-purpose orientations, moral convictions, accepted goals or prescriptions, moral principles, etc.

2. The resources of the reflexive-sensory sphere (the resources of reflection) contribute to the self-knowledge, understanding of the situation and personal significance of the professional, personal qualities necessary to achieve the goals and the desired quality of life.

16 Maksymenko, S. D., Klymenko, V. V., Tolstoukhov, A. V. Psykholohichni mekhanizmy zarodzhennia, stanovlennia ta zdiisnennia osobystosti. K.: Vyd-vo Yevropeiskoho universytetu, 2010. 136 s. 
Essential reflexive qualities of the individual as the actor are manifested in the experiences of "prosperity - nonprosperity", in the awareness of the presence or absence of important qualities, conditions, resources, strong personal qualities. At the verbal level, they are represented by the search for answers to the question: who am I? what am I capable of? what can I do? what do I know? ${ }^{17}$

3. Planning resources (cognitive-programming constructs) i.e. resources of planning and self-determination are the values of the actions planned, the desired probable increase in external and internal conditions, necessary, according to the actor himself, for the successful implementation of the activity and the achievement of the goals. Subjectively they are represented in one's consciousness as a conception, self-esteem of what I have (what resources I posess), what physical, energetic, psychological resources (significant material and spiritual objects, skills, competences) I lack, what is necessary and what I can obtained under certain circumstances with a certain probability.

4. Self-support resources, collectively referred to as self-support and self-promotion resources, are probable values of confidence in the ability to achieve goals, realize plans, and ambitions. These are mechanisms for ensuring control over situations, stability of functioning and subjective activity, determination and correction of criteria of success and proofs of achievement of goals of behaviour and activity, life philosophy in relation to circumstances and situations, etc. As "instrumental" qualities self-support resources are manifested in the awareness what helps to achieve the goals, what the actor believes in, what he or she is guided by, and what he / she hopes for. They find their expression in a life philosophy, positive self-respect, positive thinking, positive attitudes (dispositions).

5. Resources of realization and overcoming i.e. preferred ones and attractive ways of organization of activity and behaviour, coping strategies are cognitive, motivational-volitional, emotional, behavioral efforts that contribute to overcoming professional and personal difficulties, situations and circumstances, hinder the solving of the

${ }^{17}$ Petrovskyi V. A. Lichnost v pcikholohii: paradigma subiektnosti. Rostov-naDonu: Izd-vo «Feniks», 1996. 512 s. 
current tasks, fulfillment of the goals and interests of the actor. In a dynamic aspect, realization resources are coping-strategies that are used now and in the future, as well as the values of the possible "increase" in the attractiveness of constructive ways of cognitive and behavioral co-ownership.

Essential qualities of the individual as the actor of overcoming difficulties are manifested in volitional qualities, attitude to difficult situations as to "challenges", psychological maintenance of effective professional activity and preservation of health of the actors of labour. Expansion of conceptions about human resources as the actor of labour seems productive in terms of applied aspects of management psychology, psychology of professional and personal development, stress management, prevention of personal destruction, in particular to counteract professional burnout.

6. The resources of self-control of achievements are subjectively reflected in the experiences of mental and material well-being, satisfaction / dissatisfaction with self-regulation, self-realization, selffulfillment. They are subjectively represented in the verbal formulas "satisfied - not satisfied", "happy - unhappy" and in subsequent adjustments, changes in the system of life views, positions, intentions, and goals. The discrepancy between the expected and achieved results, acquisitions, rewards is considered as a probable risk of violation of subjective activity and involution of resources of conscious psychological regulation, which finds expression in semantic alienation. In the subjective and dynamic aspect of professionalization the resources of counteraction to occupational and personal distortions, including professional burnout, are represented by the available and strategic means and conditions for the realization of the desired human goals as the actor. Resources of counteraction to professional burnout are understood as temporally selective and spatially specific external and internal conditions (opportunities) of the actor of life-sustaining activity, including the actor of professional activity.

\section{CONCLUSIONS}

Thus, the conceptualization of resources of labour actors as factors of situational and strategic adaptation, self-realization, professional productivity is promising for the theory and practice of psychological assistance under occupational distortions in the form of 
burnout syndrome and can be implemented in scientifically substantiated technologies of psychological support for effective professional activity and preservation of health of the actors of labour. Expansion of conceptions about human resources as the actor of labour is considered productive in terms of applied aspects of management psychology, psychology of professional and personal development, stress management, prevention of personal destruction, in particular to counteract professional burnout.

\section{SUMMARY}

The article presents theoretical and methodological approaches to operationalization of the concept of "personal resources" in psychology. A wide range of topical problems of human resources provision as an actor of labour, as well as ambiguity of the concept of resources and their classification have been distinguished. On the basis of analytical generalization of resource theories and approaches, author's interpretations of psychological and personal resources of the actors of labour and the subject-resource concept of counteracting professional and personal deformations on the example of the countermeasures taken to prevent professional burnout of the actor of labour have been presented.

\section{REFERENCES}

1. Ananev B. G. Chelovek kak predmet poznanyia. L.: Izd-vo LGU, 2009. $324 \mathrm{~s}$.

2. Hrinova O. M. Psykholohiia proektuvannia zhyttievoho shliakhu osobystistiu yunatskoho viku: dys.. d-ra psykhol. n. Natsionalnyi pedahohichnyi universytet imeni M. P. Drahomanova, K., 2018. $562 \mathrm{~s}$.

3. Hobfoll S. E. Conservation of resources: A new attempt at conceptualizing stress. American Psychologist. 1999. Vol. 44(3). P. 513-524.

4. Hrimak L. P. Rezervy chelovecheckoi pcikhiki: Vvedenie v psikholohiyu aktivnosti. M.: Politizdat, 1989. 319 s.

5. Kapieva K. R. Psikhicheskiy resurs lichnosti: patterny y determinanty razvitiya. Nauchno-prakticheskiy zhurnal "Humanizatsiya obrazovaniya”, 2015. № 3. S. 75-81. 
6. Kazanzhy M. Y. Osobystisni resurcy podolannia pcykholohichnoi kryzy. Visnyk Natsionalnoi akademii Derzhavnoi prykordonnoi sluzhby Ukrainy. Seriia: Psykholohiia. 2015. Vyp. 1. Rezhym dostupu: http://nbuv.gov.ua/UJRN/Vnadpn_2015_1_6

7. Kokun O. M. Optymizatsiia adaptatsiinykh mozhlyvostei liudyny u pcykhofiziolohichnomu zabezpechenni diialnosti: dys... d-ra pcykhol. nauk. Instytut pcykholohii im. H. S. Koctiuka APN Ukrainy. K., 2004. $426 \mathrm{~s}$.

8. Korolchuk V. M. Psykholohiia stresostiikosti osobystosti: dyc. kand. psykhol. nauk. Instytut psykholohii im. H. S. Koctiuka APN Ukrainy. K., 2009. 513 s.

9. Levit L. Z. Psykholohiia rozvytku ta realizatsii zhyttievoho potentsialu subiekta: dys.. d-ra psykhol. n. Instytut psykholohii imeni H. S. Kostiuka NAPN Ukrainy. Kyiv, 2016. 605 s.

10. Leontoev D. A. Vvedeniye: lichnoctyi potentsial kak obiekt izucheniya. Lychnostnyi potentsial: struktura y diahnostika. M.: Smysl, 2011. S. 5-11.

11. Maksymenko, S. D., Klymenko, V. V., Tolstoukhov, A. V. Psykholohichni mekhanizmy zarodzhennia, stanovlennia ta zdiisnennia osobystosti. K.: Vyd-vo Yevropeiskoho universytetu, 2010. $136 \mathrm{~s}$.

12. Manokha I. P. Psykholohiia potentsialu indyvidualnoho buttia liudyny: ontolohichno oriientovanyi pidkhid: dys.. d-ra psykhol. n. K., 2002. $373 \mathrm{~s}$.

13. Miliutina K. L. Traiektorii zhyttievoho shliakhu osobystosti v dynamichnomu seredovyshchi: monohrafiia. Nizhyn: TOV "Vydavnytstvo "Aspekt-Polihraf", 2012.298 s.

14. Panok V.H., Rud H. V. Psykholohiia zhyttievoho shliakhu osobystosti: monohrafiia. K. : Nika-Tsentr, 2006. $280 \mathrm{~s}$.

15. Petrovskiy V. A. Lichnost v psikholohii: paradigma subiektnosti. M.: Izd-vo Voronezhskogo un-ta, 1996. $232 \mathrm{s.}$

16. Petrovskyi V. A. Lichnost v pcikholohii: paradigma subiektnosti. Rostov-na-Donu: Izd-vo "Feniks", 1996. 512 s.

17. Safin O. D., Baranov O. M. Osnovni rezultaty diahnostychnoho doslidzhennia osnovnykh komponentiv osobystisnoho potentsialu maibutnikh fakhivtsiv inozemnoi movy. Visnyk Viiskovoho instytutu KNU imeni Tarasa Shevchenka, Seriia "Psykholohiia”, 2009. № 23. S. $77-81$. 
18. Tatarko A. N. Sotsialno-psikhologicheskii kapstal lschnocts $\mathrm{v}$ polskulturnom obshchestve: diss. d-ra psikhol. n. M., 2014. 403 s.

19. Timchenko A. V. Professionalnyi stres rabotnikov OVD Ukrainy (kontseptualizatsyia, prohnozirovaniya, diahnostika i korrektsiya): diss. ... d-ra psikhol. nauk. Kharkov: NUVD, 2003. $427 \mathrm{~s}$.

20. Tolochek V. A. Professionalnaia uspeshnost: ot sposobnostei $\mathrm{k}$ resursam (dopolniaiushchye paradyhmy). Psikholohyia. Zhurnal Vysshei shkoly ekonomiki. 2009. T. 6. № 3. S. 27-61.

21. Vodopianova N. E. Sovremennye kontseptsii resurcos subiekta professionalnoi deiatelnosty. Vestnik CPbHGU. Ser. 16. 2015. Vyp. 1. S. 45-54.

\section{Information about the author:}

Anatolii Yakymchuk

Candidate of Psychological Sciences,

Senior lecturer of the Border Service Department National Academy of the State Border Guard Service of Ukraine named after Bohdan Khmelnytskyi 46, Shevchenko str., Khmelnytskyi, 29003, Ukraine ORCID ID: orcid.org/0000-0002-2729-8201

E-mail: anatoliy_yakimch@ukr.net 


\section{PROFESSIONAL REFLECTION IS A FACTOR OF IMPROVING THE TEACHER'S PROFESSIONALISM}

\section{Tetiana Scherban}

\section{INTRODUCTION}

At the present stage of society development, high requirements are set to the professionalism of a specialist. A modern specialist is a person who is able to analyze, adjust and improve his/her professional activity. A prerequisite for this improvement is professional reflection.

The rapid changes in society influence the changes of the higher education. After all, the criteria for assessing the effectiveness of specialists have changed. This fact determines the process of systemic reform of the higher education system. In particular, in modern professional psychological models of an ideal specialist, those mental properties that affect the ability to self-development and professional self-improvement acquire more and more importance. In this context, the leading personality trait is reflection. Therefore, an important task of education is to create optimal conditions for the formation and development of professional reflection of future specialists.

As the analysis of the psychological and pedagogical literature shows, the essence of reflection, its mechanisms, processes, methodological, theoretical, experimental and applied problems, have been covered in the researches of S. Yu. Stepanova, M. A. Vislohuzova, N. I. Poviakel, N. O. Postaliuk, Yu. M. Shvalba, T. M. Shcherbakova, and others). Many aspects of reflection have been investigated in the works of many scientists: the place of this phenomenon in the system of professionally significant qualities (E. O. Klimov, M. S. Pryazhnikov, O. F. Bondarenko, L. V. Dolynska, V. H. Panok, N. V. Chepeleva and others); reflection and professional thinking (N. I. Poviakel, M. Yu. Verban, N. V. Prorok, etc.); the role of reflection in axiogenesis (V. M. Mytsko, Z.S. Karpenko, H. K. Radchuk, etc.); reflection in the process of self-actualization of the personal and professional "Self" (Yu. H. Dolinska, L. M. Kobylnik, D. A. Menegetti, etc.); reflection in the formation of professional consciousness (A. A. Alimov; N. O. Kucherovska, N. F. Shevchenko 
and others); reflection and professional identification (T. M. Buiakas, O. O. Minenko, L. B. Schneider, etc.).

The study of professional reflection is an urgent task for all pedagogical specialties. After all, today the school needs a teacher who is able to work independently, creatively and responsibly at a high professional level, to think creatively, to act professionally in problem situations.

The effectiveness of pedagogical activity depends crucially on the level of development of pedagogical reflection. Pedagogical reflection is not just about knowing or understanding the subject itself, it is also about finding out how others know and understand the "reflector", his or her personal characteristics, emotional reactions, and cognitive ideas.

It is believed that the level of reflexive self-regulation of the teacher influences his/her professional skill and is the psychological basis of his/her pedagogical creativity (I. P. Rachenko ${ }^{1}$, M. V. Klarin ${ }^{2}$, Yu. M. Kulutkin, N. O. Postaliuk, etc.). After all, as a form of cognition, reflection is inherent not only critical but also a heuristic principle: it acts as a source of new knowledge. Being aware of the unconscious, cognizing the unknown, reflection considers knowledge about it to be its subject.

E. F. Zeier ${ }^{3}$, E. O. Klimov ${ }^{4}$, A. K. Markova have repeatedly emphasized that professional reflection promotes creative search and improvement of professionalism.

The importance of professional reflection for the process of professionalization is also emphasized in a competent approach. The concept of "reflexive competence" is proposed by O. A. Polishchuk. According to the scientist, reflexive competence is a professional quality of a person, which allows the most efficient and adequate implementation of reflexive processes, the implementation of reflexive

1 Rachenko Y.P. (1999) Psychology of pedagogical creativity. Pyatigorsk: Publishing house of PSLU.

${ }^{2}$ Klaryn M. V. (1994) Innovative models of teaching in foreign pedagogical searches. Moscow.

${ }^{3}$ Zeer E. F. (2003) Psychology of vocational education. Moscow: Publishing House of the Moscow Psychological and Social Institute.

${ }^{4}$ Klymov E. A. (1996) Psychology of professional self-determination. Rostovon-Don: Phoenix. 
ability, which ensures the process of development and selfdevelopment ${ }^{5}$. The criterion of effective pedagogical activity is the ability of the teacher to solve pedagogical and educational tasks. Reflection in this process is the basis of success.

A number of researchers pay attention to the role of reflection in cognition, awareness and self-esteem of professionally significant qualities (V. D. Bragina, V. M. Koziev, V. P. Savrasov, L. O. Hryhorovych, etc.). It is believed that the most important condition for the development of the professionalism of the teacher, an important factor in the effectiveness of his/her pedagogical activity is the teacher's readiness (willingness) to constant "feedback", his/her ability to interpret the information obtained from the school cild's position, to evaluate the effectiveness and appropriateness of the pedagogical decisions that he/she makes, the correctness of approaches to problem situations, etc. ${ }^{6}$. That is, reflection shapes the teacher's perceptual skills.

Despite versatile and thorough research in the theoretical and empirical fields of studying pedagogical reflection, the role of reflection in shaping the ability to solve pedagogical tasks and the development of perceptual skills remains poorly studied. All of the above defines the purpose of the study - to study theoretically and empirically the psychological features of pedagogical reflection in the processes of problem solving and the development of perceptual skills. The object of study is pedagogical reflection. The subject of the study - psychological features of pedagogical reflection in the process of solving problems and developing perceptual skills. According to this purpose, the main tasks of the study have been determined: to study the psychological features of teacher's reflection in the process of solving pedagogical tasks; to study the psychological features of the teacher's reflection in the development of his/her perceptual skills.

${ }^{5}$ Stepanov S. Yu., Polyshchuk O. A. \& Semenov Y. N. (1996) The development of reflective competence of management personnel. Moscow: Progress.

6 Tkachuk S. I. (2010) Psychological and pedagogical bases of professional readiness of future teachers of labor training to formation of technological culture of students in general educational establishments. Scientific journal of MP Dragomanov National Pedagogical University. Series 13: Challenges for Employment and Training, vol. 6. pp. 200-207. 


\section{Psychological features of teacher's reflection in the process of solving pedagogical tasks}

The teacher is not allowed to perform his/her activities in a nonprofessional manner, since the object of his/her influence is the schoolchildren. It is a typical idea that in order to be a good teacher it is necessary to have a thorough knowledge of the subject and have practical experience. The fact is that these are only necessary but not sufficient conditions for the formation of the professionalism of the teacher. Only the constant awareness, analysis and systematization of experience enable the teacher to develop as a professional. The reflexive attitude of the teacher to his/her own activity is an important factor in his/her thorough awareness, critical analysis, and constructive improvement. Thus, reflection enables the individual to go beyond the immediate process, beyond the routine, to take a stand outside it for analysis and drawing conclusions.

In pedagogical activity, the reflexive processes are implemented primarily in the process of:

- interaction of a teacher with a schoolchild. The criterion is the teacher's understanding of the schoolchildren's actions, feelings, and thought processes;

- designing schoolchildren's activities. The criterion is the teacher's development of learning and upbringing goals, constructive ways of achieving them, taking into account the abilities and psychological characteristics of schoolchildren;

- introspection and self-esteem. The criterion is the assessment of one's own activity and oneself as its subject of pedagogical activity.

Pedagogical reflexive actions are manifested in the following:

- in the desire of the teacher to understand the internal mechanisms of the learning process, find out why some teaching methods are effective, while others do not contribute to the promotion of the child, identify some general patterns that govern the learning process, etc., that is, in an effort to get to the bottom of all the phenomena that did not seem to him/her problematic before;

- in the productive nature of the teacher's analysis of his/her practical experience, allows him/her to be "estranged", accessible only for further understanding in the context of the experience of science and its transfer to other people; 
- in the constructive orientation of the reflexive analysis of one's own activity, which allows the teacher to distinguish individual independent tasks from the general structure, the solution of which requires own special methods and approaches. Yes, the learning process can be considered as a process of sequential execution of analytical tasks, that allows the teacher to more differentially approach the search of means for their realization ${ }^{7}$.

The role of reflection in the process of analyzing the teacher's own constructive and methodical schemes, which he/she uses in the process of solving educational problems, is important. The existence of a direct relationship between the teacher's orientation to independence in the design of educational solutions, the level of formation of his/her professional reflection and the methods of selecting information from various sources has been proved. Moreover, it is the reflexive attitude of beginners to themselves as subjects of professional activity that is the basis for the development of pedagogical reflection in them as a necessary condition for professionalism.

The criterion for the professional development of teachers is the ability to successfully solve educational and pedagogical problems ${ }^{8,9,10}$. Such skills can not be developed without an active reflective attitude of the individual. Thus, reflection is the key to forming the ability to solve learning problems.

Educational activity is a continuous series of tasks. Teachers need to be taught how to solve them. The ability to solve educational and pedagogical tasks is also an important criterion for the quality of the acquired knowledge and practical skills, a criterion for qualitative training of future specialists at higher educational institutions. Successful learning process to solve educational and pedagogical problems can be subject to the reflective position of the teacher's personality.

${ }^{7}$ Halkyna N. V. (1990) The psychological mechanism for solving problems of assessment and self-esteem. Psychology of creativity. pp. 149-158.

${ }^{8}$ Kulyutkyna Yu. N. \& Sukhobskoy H. S. (1990) Teacher Thinking: Personal mechanisms and conceptual apparatus. Moscow: Pedagogy.

${ }^{9}$ Slastenyn V. A. (1976) The formation of the personality of the teacher of the Soviet school in the process of training. Moscow: Prosveshchenye.

${ }^{10}$ Sokolova E. T. (1989) Self-awareness and self-esteem in case of personality anomalies. Moscow: Moscow State University. 
This prompted us to conduct studies on the preparedness of teachers and future teachers to solve educational problems. The group consisted of 150 people (80 graduates of pedagogical specialties, 70 young specialists with work experience up to 5 years). The purpose of this study was the assessment by experts the preparedness of respondents to solve pedagogical problems. The results of the assessment were expressed in the following gradation of the preparedness levels of respondents:

Very low level: the actions of the teacher are not grounded or conscious; pedagogical activity does not meet the requirements of the principles of science and education.

Low level: the actions of the teacher are partially substantiated and partly conscious, significant mistakes are possible; pedagogical activity partially meets the requirements of the principles of education and upbringing.

Middle level: the actions of the teacher as a whole are substantiated and conscious; pedagogical activity as a whole meets the requirements of the principles of education and upbringing; designed activities are completed in a timely manner; there is a considerable degree of independence.

High level: the actions of the teacher are fully justified and conscious; pedagogical activity fully meets the requirements of the principles of education and upbringing; high level of independence; projected activities are completed on time.

The table summarizes the results of expert assessments.

Table 1

Summarized results of expert assessments (in \%)

\begin{tabular}{|c|c|c|c|c|}
\hline \multirow{2}{*}{ Respondents } & \multicolumn{4}{|c|}{ Preparedness levels } \\
\cline { 2 - 5 } & $\begin{array}{c}\text { high } \\
\text { level }\end{array}$ & $\begin{array}{c}\text { medium } \\
\text { level }\end{array}$ & $\begin{array}{c}\text { low } \\
\text { level }\end{array}$ & $\begin{array}{c}\text { very low } \\
\text { level }\end{array}$ \\
\hline \multicolumn{1}{|c|}{ Graduates } & 11 & 27 & 39 & 23 \\
\hline $\begin{array}{l}\text { Young teachers } \\
\text { (with experience } \\
\text { up to 5 years) }\end{array}$ & 19 & 29 & 35 & 17 \\
\hline
\end{tabular}


The results obtained indicate the following trends:

1. There is an increasing number of teachers with a high and medium level of readiness to solve pedagogical tasks. This is a consequence of the adaptation of young teachers to their professional activities, their self-education and self-upbringing.

2 . There is a fairly large proportion of graduates with a low and very low level of preparedness for solving pedagogical problems. It is advisable to emphasize that positive dynamics was diagnosed depending on the length of service, but it is very insignificant and does not satisfy modern requirements.

The analysis of conversations with graduates and young teachers, regarding their use of modern innovative methods in the practical work, concepts of psychology and pedagogy, revealed that real pedagogical activity can be performed at empirical and conscious levels.

The empirical level demonstrates the realization of only the external, substantive side of pedagogical activity, when teachers apply a method of action according to the logic of practical action. However, that logic does not reflect the systemic linkages between the components of the pedagogical process, which is the competence of the theory. Teachers are not able (and do not understand the need) to justify what course of actions and why they were chosen in a particular situation. They just act in a similar way to other teachers.

The conscious level demonstrates the realization that the external objective activity comes out of the previous internal, theoretical work. Thus, the teacher first comprehends the goals and determines the expected results, plans actions, the conditions for their implementation. A. N. Leontyev noted that conscious action, he emphasizes, is a process subordinated to a conscious goal, which leads to a predicted result $\mathrm{t}^{11}$.

Very often there is a discrepancy between the processes of teachers' acquisition of theoretical knowledge and the accumulation of practical experience. These processes seem to coexist in parallel, do not overlap. All this indicates that the theory is not the basis for understanding and choosing the solution of pedagogical problems,

11 Leont'ev A. N. (1975) Activity. Consciousness. Personality. Moscow: Polytyzdat. 
teachers do not use the acquired knowledge to make constructive schemes of problem solving, especially those who have a low or very low level of readiness to find practical solutions.

Interviews with respondents who demonstrated a high and middle level of preparedness to solve pedagogical problems indicate that young professionals (including graduates) are able to use analysis, generalizations, critically reflect on their own experience, observe and use the experience of others. That is, they are in a reflexive position, which has allowed them to succeed.

Respondents who have demonstrated a low and very low level of readiness to solve pedagogical problems are not able to analyze, make generalizations, do not comprehend their own experience, and use the experience of others formally, without understanding, intuitively in their actions. That is, they do not know how to use reflection. This is what led to their result.

Therefore, in order to formulate the ability to solve pedagogical problems, it is necessary to systematically and purposefully develop reflection, reflexive processes. Such organization of these processes will enable the teacher to develop as a professional.

\section{Psychological features of teacher's reflection in the process of developing perceptual skills}

The defining aspects of human existence are subject activity and communication. Of course, there are various interconnections and transitions between them, but this does not exclude their fundamental specificity. The central system-forming attitude that underlies the learning activity and defines its essence is the "teacher-schoolchildren" attitude. The subject of the teacher's activity is the schoolchildren's educational activity. He/she must organize and regulate it in accordance with the tasks of training and their upbringing, subordinated, in turn, to the more general goal of developing the moral and spiritual world of the latter, the formation of the value-semantic sphere of their personality. So, reflexive activity aimed at the schoolchild has its own characteristics. According to the results of various studies, the priority concentration of professional reflective analysis on the schoolchild is not only a consequence of the influence of any situational factors or personal qualities of the teacher, but also 
largely represents the result of the teacher's professional evolution, a reflection of his/her high level of professionalism ${ }^{12}$.

The main guideline of the reflective consciousness of the teacher, that directs and organizes all his/her actions, is the schoolchild. However, the formation of this guideline does not occur immediately and not spontaneously. This process happens with the help of perceptual processes (understanding of the schoolchild, his/her actions), the processes of establishing relationships, the process of partnership communication.

Communicative reflection is close to cooperative one. Close interaction in the communication process acts as a way of actualizing relationships. Psychological dynamics of communication, which allows establishing and maintaining contacts, exchanging information, maintaining interaction and mutual influencing one another, contributes to the realization and formation of a new level of relationships. Relationships are, first and foremost, the object of subject-personal reflection, and they allow us to adjust the content, style, form of communication.

Experimental work on identifying the basic psychological and educational parameters of perceptual activity in pedagogical interaction was carried out with 18 teachers and 57 schoolchildren. The work was aimed at studying the personal psychological properties and capabilities of the teacher, which form the basis of perceptual interaction. The following psychodiagnostic techniques have been applied in the study: The T. Leary methodology for the diagnosis of interpersonal relations, the $M$. Rokich methodology of value orientations, the Philips methodology for diagnosing the level of school anxiety, author's questionnaire. Methodology of statistical data processing have been applied in the analysis of the obtained results.

In educational communication, it is important for the teacher to understand what the schoolchild perceives as important, meaningful. For this purpose, a survey among schoolchildren and teachers was conducted. The schoolchildren were required to rank the communicative characteristics of the teacher for their importance. Teachers should have ranked the communicative characteristics for

${ }^{12}$ Belukhyn D. A. (1994) Teacher: from love to hate ... Moscow. 
schoolchildren. That is, the purpose of the questionnaire was to investigate how teachers understand their schoolchildren.

The following results have been obtained. Teachers believe that the following characteristics are important for schoolchildren: "the ability to express their opinions and their attitude" (I rank), "novelty of information" (II), "the ability to ask questions" (III); "Respect" (IV) and "logic and simplicity of information" (V). Schoolchildren distinguish the following characteristics: "logicality and simplicity of information" (I), "opportunity to ask questions" (II), "opportunity to express their opinions and their attitude" (III), "respect" (IV) and "novelty of information" (V). Thus, we see differences in the answers: teachers choose characteristics that are inherent in the professionalism of communication, and schoolchildren emphasize characteristics that are inherent in the dialogue communication.

A survey of schoolchildren allowed us to highlight the qualities that schoolchildren want to see in their mentors: sociability, a polite attitude to the interlocutor, the ability to hear the opinion of another, a sense of humor, kindness. Among the characteristic reasons that hinder the establishment of trusting relationships with teachers, schoolchildren primarily mention: teacher indifference, neglect, orientation to authoritarianism, lack of understanding of the interests of another, imposing his/her opinion, inability and unwillingness to listen to the interlocutor, complaints and notations, and the like. In fact, we are talking about the subconscious desire of schoolchildren to implement dialogical communication. Interviews with teachers made it possible to identify the qualities that they most often use in communicating with schoolchildren: persuasion, control of their emotions, the use of non-verbal means, and a variety of information. In fact, we are talking about the subconscious orientation of teachers to authoritarian methods of managing schoolchildren.

For a more thorough analysis of communicative aspirations, the Leary Questionnaire was used. The results of the study on average values are presented in Fig. 1. 


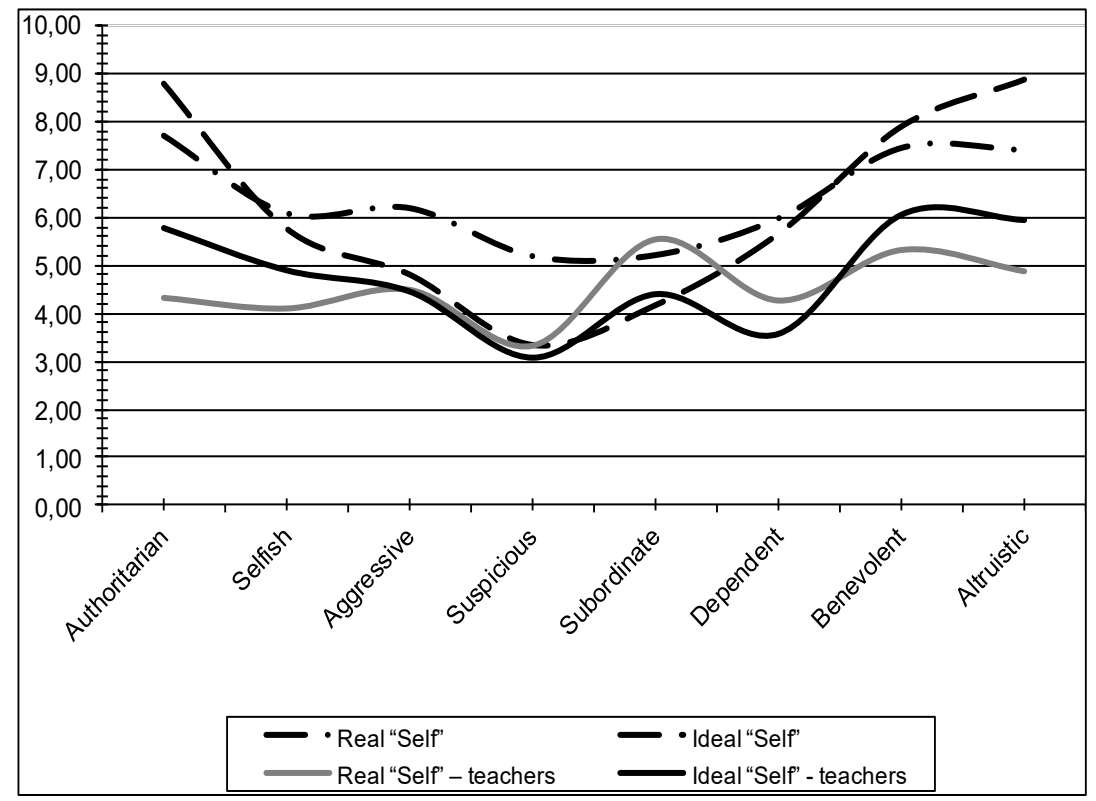

Fig. 1. Results of the study according to the Leary questionnaire

The results obtained allow us to distinguish the following trends:

- both schoolchildren and teachers, in their ideal self, tend to increase authoritarianism. This confirms once again the acknowledged problem of teachers - high authoritarianism, and the desire to increase it ideally is alarming. Schoolchildren, in turn, copy the behavior of the teacher and also tend to increase authoritarianism;

- on the scale of selfishness schoolchildren's real and ideal coincide. It should be emphasized that, ideally, teachers see themselves even more selfish. This is confirmed by the trend of the authoritarianism scale;

- ideally, schoolchildren tend to reduce aggression and suspicion. Teachers do not see significant differences between the real and the ideal state of affairs;

- on the scale of "subordination" and "dependence" we find quite unexpected results. Both groups lack freedom; ideally they see less subordination, both categories are under heavy pressure of social circumstances, they feel uncomfortable; 
- positive trends include the tendency to increase benevolence and altruism in both groups, which indicates the possibility of working with both categories of subjects and the fact that emotional burnout has not yet reached a threatening scale.

The generalized results by the T. Leary's method of own ideas about the real self and ideal self of teachers and schoolchildren are presented in Table 2 .

Table 2

The results of the study by the method of $T$. Leary

\begin{tabular}{|l|c|c|c|c|c|c|c|c|}
\hline \multirow{3}{*}{ Scales } & \multicolumn{3}{|c|}{ The real "Self" } & \multicolumn{4}{c|}{ Ideal "Self" } \\
\cline { 2 - 10 } & $\begin{array}{c}\text { school } \\
\text { children }\end{array}$ & \multicolumn{2}{c|}{ teachers } & \multicolumn{2}{c|}{$\begin{array}{c}\text { school } \\
\text { children }\end{array}$} & \multicolumn{2}{c|}{ teachers } \\
\cline { 2 - 10 } & $M$ & $\sigma$ & $M$ & $\sigma$ & $M$ & $\sigma$ & $M$ & $\sigma$ \\
\hline Authoritarian & 7,68 & 3,07 & 4,33 & 3,20 & 8,77 & 3,46 & 5,78 & 3,59 \\
\hline Selfish & 4,06 & 2,62 & 4,11 & 2,22 & 5,74 & 2,63 & 4,89 & 2,61 \\
\hline Aggressive & 6,17 & 3,08 & 4,50 & 2,55 & 4,79 & 2,55 & 4,44 & 2,75 \\
\hline Suspicious & 5,17 & 2,89 & 3,33 & 2,50 & 3,32 & 2,60 & 3,06 & 2,39 \\
\hline Subordinate & 5,19 & 3,00 & 5,56 & 1,82 & 4,15 & 2,65 & 4,39 & 2,70 \\
\hline Dependent & 5,96 & 2,67 & 4,28 & 2,65 & 5,64 & 3,02 & 3,56 & 2,20 \\
\hline Benevolent & 7,43 & 2,91 & 5,33 & 2,63 & 7,87 & 3,51 & 6,06 & 3,21 \\
\hline Altruistic & 7,38 & 3,35 & 4,79 & 3,45 & 8,85 & 3,75 & 5,94 & 3,78 \\
\hline
\end{tabular}

The findings confirm the crisis of schoolchild-teacher interaction and the inability of existing methods to overcome it: the system of interaction mainly works in a stressful mode for both teachers and schoolchildren, does not suit both parties and requires finding ways to solve the problem.

The peculiarities of anxiety were investigated by the Phillips method. The analysis of the results indicates a significant polarization of the data on the "Overall anxiety at school" scale (standard deviation 4.69). From the additional subscales of the method it is necessary to pay attention to the high value on the scale "Frustration of the need for achievements" (4.11). Thus, we associate the high results on the scale of frustration of the need for achievement with the high values of the reduction of personal achievements among teachers. In other words, this is the spread, translation of the effects of burnout on schoolchildren. 
The results of overall anxiety are also at a high level $(17,23)$, which is an indicator of the problems of pedagogical interaction between teacher and schoolchild. We associate a high level of fears of interaction with such a brightly high value of authoritarianism and independence among students. They are trying to defend themselves from the teacher.

Table 3

The results of the Philips' methodology for diagnosing the level of school anxiety

\begin{tabular}{|c|c|c|c|c|c|c|c|c|c|}
\hline & 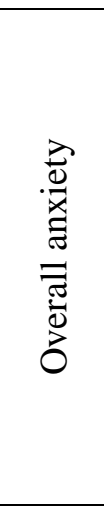 & 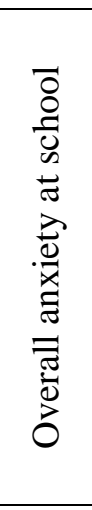 & 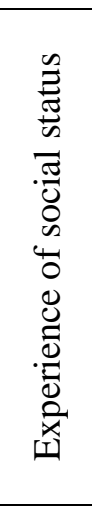 & 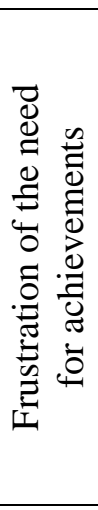 & 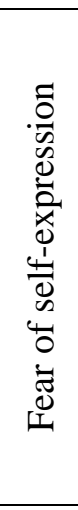 & 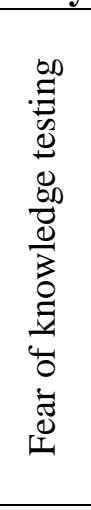 & 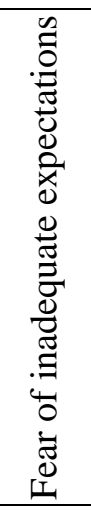 & 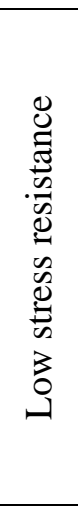 & 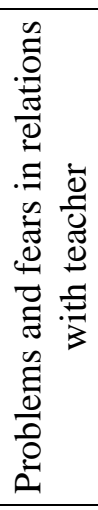 \\
\hline$M$ & 17,23 & 6,60 & 2,81 & 4,11 & 2,23 & 2,49 & 2,26 & 1,28 & 3,11 \\
\hline$\sigma$ & 8,02 & 4,69 & 1,88 & 1,60 & 1,83 & 1,57 & 1,31 & 1,28 & 1,51 \\
\hline
\end{tabular}

Value orientations are general regulators of human behavior and are manifested in absolutely all spheres of human activity, it is virtually impossible to fully characterize any phenomenon of public or individual life without addressing the problem of values and value orientations. Therefore, the next stage of the study was the analysis of value orientations by the Rokich method (see Fig. 2 and Fig. 3).

Assessing the terminal values of schoolchildren and teachers, we can conclude that the schedule is very similar, and, consequently, the structure of values. Only high values on the scale of "life wisdom" among schoolchildren and on the scale of "having friends" among teachers cause confusion. 


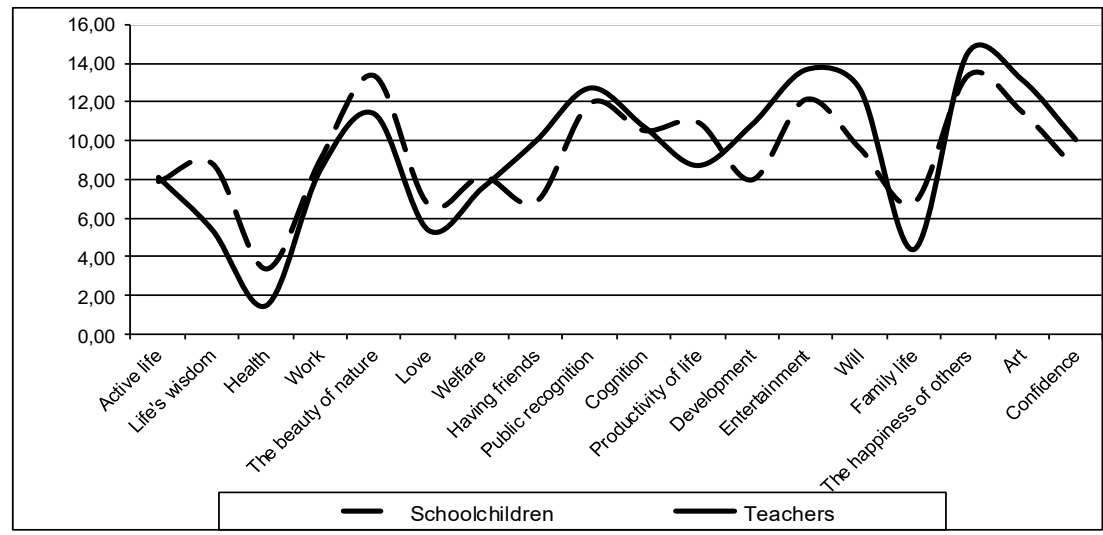

Fig. 2. Terminal values by Rokich method

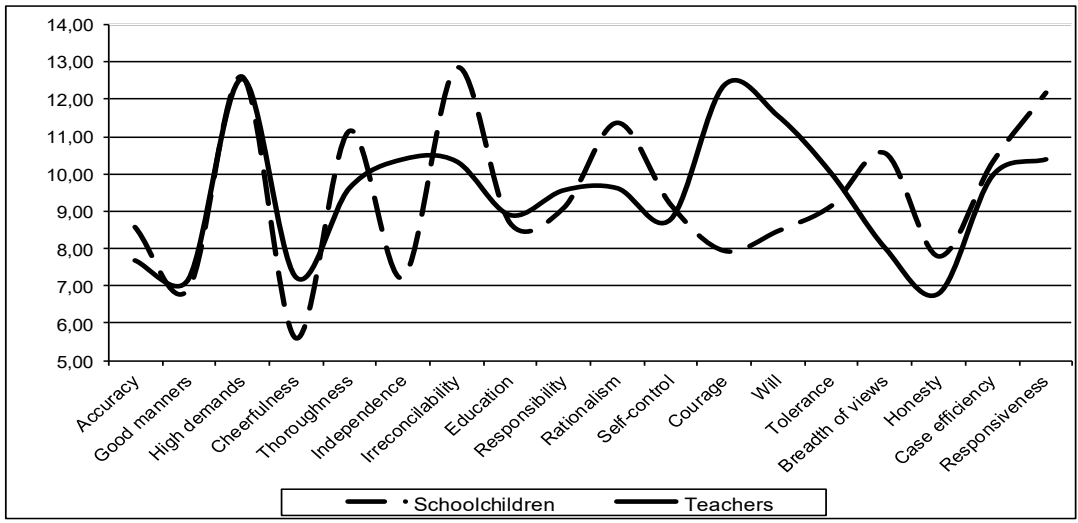

Fig. 3. Instrumental values by the method of Rokich

Instrumental values are much more polar, and the curves of schoolchildren and teachers. The will, courage, self-control are significantly higher among teachers, while "irreconcilability" and "breadth of views" are higher among schoolchildren. Most results are explained by age-related changes, life experiences. At the same time, low indicators of the level of honesty as values among teachers, not too high responsibility, low level of responsiveness, which is a disappointing conclusion on the personal and professional development of the studied teachers, are of concern. 
The next stage of the study is a statistical analysis of the results obtained. Correlation analysis determines the extent of the relationship between different questionnaire scales. The results are noteworthy: overall anxiety (0.731) and overall anxiety at school (0.664), fears of knowledge testing (0.688), inconsistencies (0.435) and relationships with the teacher $(0.428)$ are found to be correlates of stress resistance. In other words, a deep experience of increased anxiety and fears is a means of training stress resistance.

The applied factor analysis made it possible to distinguish the scales with the highest factor loads. The result was a three-factor model that included all the questionnaires. Based on the graph of eigenvalues, a factor matrix has been obtained. In the analysis, the Kettel criterion was used. We note that the factor loads of the extracted factors are high: $20 \%, 18 \%$, and $16 \%$ for the 1st, 2nd, and 3rd factors, respectively, allows us to conclude not only the equivalence of factors, but also the qualitative results of actual factorization.

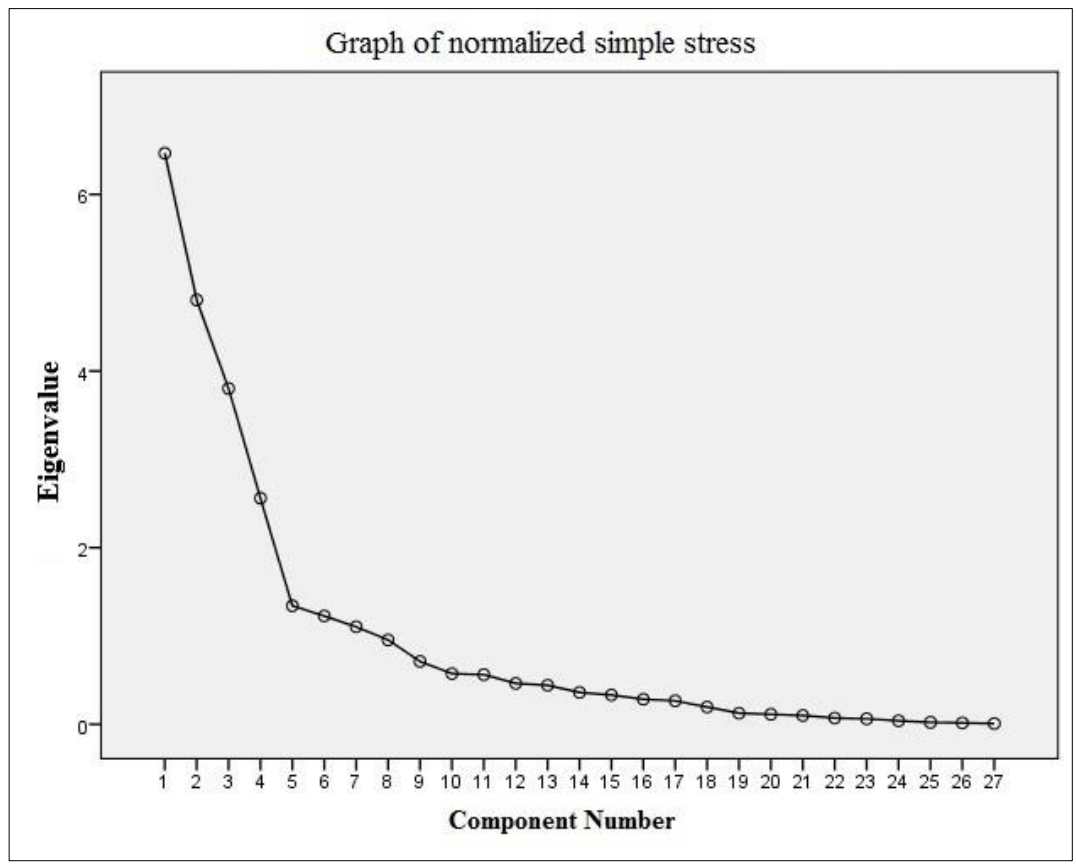

Fig. 4. Graph of the eigenvalues of the obtained factors 
Factor distribution analysis: primary eigenvalues, the sum of the squared factor loads for the extracted factors and the sum of the squared factor loads after rotation is necessary to determine the proportion of variance, "explained" by the extracted factors are presented in Table. 4.

Table 4

The components of the total variance for the 3 factor model

\begin{tabular}{|c|c|c|c|c|c|c|c|c|c|}
\hline \multirow[b]{2}{*}{ 黾 } & \multicolumn{3}{|c|}{ Initial eigenvalues } & \multicolumn{3}{|c|}{$\begin{array}{l}\text { The sum of the squared } \\
\text { factor loads for the } \\
\text { extracted factors }\end{array}$} & \multicolumn{3}{|c|}{$\begin{array}{l}\text { Sum of squared factor } \\
\text { loads after rotation }\end{array}$} \\
\hline & $\stackrel{\frac{\pi}{0}}{0}$ & 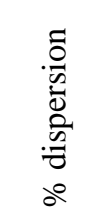 & 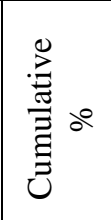 & $\stackrel{\frac{\pi}{0}}{0}$ & 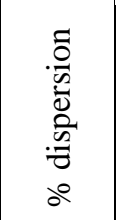 & 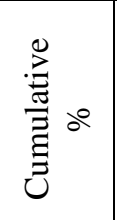 & $\stackrel{\frac{\pi}{0}}{\ominus}$ & 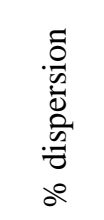 & 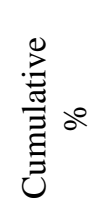 \\
\hline 1 & 00 & 7 & 2 & 466 & 9 & $2 J$, & 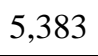 & & נוגו \\
\hline 2 & 805 & 7,795 & 41,744 & 4,805 & 17,795 & 41,744 & 4,877 & 18,064 & 38,000 \\
\hline 3 & 3,802 & 14,081 & 55,825 & 3,802 & 14,081 & 55,825 & 4,421 & 16,373 & 54,374 \\
\hline
\end{tabular}

So, the following distribution of factors has been obtained:

1. "Anxiety and fear" factor (19.94\% of the variance), which included the following indicators: overall anxiety at school, experience of social stress, frustration of need for achievement, fear of selfexpression, fear of knowledge test, fear of non-compliance, resistance to stress, problems and fear of relationships with the teacher. That is, it is an emotional state against which social contacts with peers develop; unfavorable psychological background that does not allow developing one's needs for success; negative emotional experiences of situations, demonstration of oneself and one's capabilities; orientation on the importance of others in evaluating one's results, actions, thoughts; a general negative emotional background of relationships with teachers at school that impairs the schoolchild's ability to learn successfully.

2. Subordination factor ( $18.06 \%$ of variance). The factor included indicators: dependent, benevolent, altruistic, subordinate. That is, it depends on the social environment, on professional activity, on others, 
on circumstances; display of friendliness, kindness, altruism, selflessness and a willingness to obey.

3. The "Dominance" factor (16.37\% of the variance) includes indicators: selfish, aggressive, authoritarian, suspicious. That is, putting one's own needs, desires, manifestations of aggression in communication, interaction and position; acceptance of authoritarianism or expression of authoritarianism, immutability, as well as suspicion, mistrust.

As a result of the analysis it is possible to draw the following conclusion: the basic determinants that determine the object of our study are the factors of dominance, subordination and personal experiences of states of anxiety and fear. This allows us to identify these factors as the main levers of influence for the future correction of teacher-schoolchild communication performance, which in turn will improve schoolchildren's motivation for learning and academic achievement on a global scale, and will be the direction for further research to change the structure of interaction at school in general.

Thus, the value is statistically greater than that of the schoolchildren on all scales that showed statistically significant difference. And if on most scales this is the obvious and expected result, then on the scale "dependent" we expected the opposite. However, the obtained results indicate, in general, greater development of personality traits and qualities among adults on the one hand, but on the other, the presence of occupational deformities among the investigated teachers. In addition, it should be noted that according to the Self - Ideal Scales selfishness, authoritarianism schoolchildren tend to the values of adult teachers and see a high level of selfishness and authoritarianism as the desired ideal; on the other hand, they do not aspire to ideal values on the scale of benevolence and altruism, and do not wish to ideally develop these properties. It is this that explicates, demonstrates an important social problem in society, is an alarming sign of the direction of development of modern youth and sets the task of finding ways to correct these shifts both on a cultural, macro-scale and at the level of individual polydiad teacher-schoolchild interaction.

Empirical study made it possible to single out the psychological properties of the qualities of a teacher's personality through which it is possible to indirectly influence the development of perceptual skills and professional reflection. 


\section{CONCLUSIONS}

Professional reflection (that is, the focus of consciousness on oneself as a specialist, on the content of professional actions, on performing professional tasks) is an important factor of professionalism, competence, professional maturity, as it increases the efficiency of solving a wide range of everyday pedagogical problems.

In this sense, professional reflection is an important mechanism in the process of solving pedagogical problems, since it allows a person to take an external position in relation to himself/herself and his/her actions, which makes their conscious regulation possible. Thanks to reflective learning processes, solving educational problems is more efficient and optimized. The formation of such a skill uses the reflexive mechanism of the transition of activity from the internal form to the external, that is: the deployment of already formed mental actions that are inherent in personal reflection as an ontogenetically earlier variety of reflection. The role of reflection in the process of analyzing the teacher's own constructive and methodical schemes, which he/she uses in the process of solving educational problems, is important. The existence of a direct relationship between the teacher's orientation to independence in the design of educational solutions, the level of formation of his/her professional reflection and the methods of selecting information from various sources has been proved.

Empirical study of the professional development of teachers has been carried out - the ability to solve educational and pedagogical problems. The obtained results indicate the following trends:

- increasing of number of teachers with high and medium level of readiness to solve pedagogical tasks in accordance with their practical experience. Such personalities are able to use analysis, generalizations, critically reflect on their own experience, observe and use the experience of others. That is, they are in a reflexive position, which has allowed them to succeed.

- the presence of a sufficiently large proportion of graduates of pedagogical specialties with low and very low level of readiness to solve pedagogical tasks. They do not know how to analyze, do not generalize, do not comprehend their own experience, and use the experience of others in their actions formally, by analogy. That is, they do not know how to use reflection. 
- there is a discrepancy between the processes of teachers' acquisition of theoretical knowledge and their accumulation of practical experience. These processes coexist as if they were parallel, do not overlap. All this indicates that the theory is not the basis for understanding and choosing the solution of pedagogical problems, teachers do not use the acquired knowledge to make constructive schemes of problem solving, especially those who have a low or very low level of readiness to find practical solutions.

Therefore, for the formation of the ability to solve pedagogical problems, it is necessary to systematically and purposefully develop reflection, reflexive processes. Such an organization of these processes will enable the teacher to develop as a professional.

Communicative reflection is close to cooperative one. Close interaction in the process of communication acts as a way to actualize relationships. It is relations that are, first and foremost, the object of subjective-personal reflection, it is they that allow adjusting the content, style, form of communication.

The following results of the empirical study have been obtained:

- differences in perceptions of factors that are important in educational communication have been diagnosed: teachers choose characteristics that are inherent in professional communication, and schoolchildren emphasize the features that are inherent in dialogical communication;

- the qualities that schoolchildren want to see in their mentors have been distinguished: communicativeness, polite attitude to the interlocutor, ability to hear the opinion of another, sense of humor, kindness;

- systematic psychological features of teachers that interfere with the establishment of perceptual interaction with schoolchildren: the indifference of the teacher, the superficial attitude, the focus on authoritarianism, misunderstanding the interests of others, imposing their thoughts, inability and unwillingness to listen to the interlocutor.

- schoolchildren's and teachers' aspirations in their ideal self to: increase authoritarianism; reduction of subordination; increase in benevolence and altruistic, have been diagnosed;

- a high level of anxiety has been established, which is an indicator of the problems of perceptual pedagogical interaction of teacher-schoolchild; 
- the polarity of indicators of instrumental values hs been revealed: will, courage, self-control are significantly higher among teachers; irreconcilability and breadth of views - among the schoolchildren. Such results are explained by age-related changes, life experiences.

- The teachers' low levels of honesty, responsibility and responsiveness have been identified.

Correlation analysis shows that overall anxiety (0.731) and overall anxiety at school (0.664), fears of knowledge testing (0.688), mismatch $(0.435)$ and relationships with the teacher $(0.428)$ are correlates of stress resistance. In other words, deep feelings of anxiety and fears are a means of stress training.

The applied factor analysis made it possible to distinguish the scales with the highest factor loads, namely, "Anxiety and fears", "Subordination", "Domination". These factors are the main levers of influence for the future correction of the perceptions of teacherschoolchild communication, which in turn will enhance schoolchildren's motivation for learning and academic achievement on a global scale, and will be a driving force for further research on changing interaction structures in modern school interaction.

Thus, the psychological properties of teachers who can optimize communication in training, exchange information, understand the schoolchild, evaluate the effectiveness of their actions, develop perceptivity, maintain interaction and mutual influence on each other, promote the implementation and formation of partnerships in relationships have been highlighted. It is these relationships that are, first of all, the object of subjective-personal reflection, it is they that allow adjusting the content, style, form of communication in training.

\section{SUMMARY}

A necessary condition for pedagogical improvement is professional reflection. The criteria for effective pedagogical activity are: the ability of a teacher to solve pedagogical and educational problems; development of perceptual learning relationships.

The existence of a direct relationship between the teacher's orientation to independence in the design of educational solutions, the level of formation of his/her professional reflection and the methods of selecting information from various sources has been proved. The results of 
empirical study of the process of solving pedagogical problems highlight trends: an increase in the number of teachers with a high and medium level of preparedness for solving pedagogical problems in accordance with the acquisition of experience; the presence of a sufficiently large proportion of graduates of pedagogical specialties with a low and very low level of preparedness for solving pedagogical problems; there is mismatch in the processes of teachers mastering theoretical knowledge and their accumulation of practical experience.

Learning relationships are an object of communicative reflection. The results of empirical study of communication in teaching are as follows: differences in the perception of factors that are important in educational communication have been diagnosed; the qualities that students want to see in their mentors have been highlighted; the psychological qualities of teachers that prevent the establishment of perceptual interaction with students have been systematized; the aspirations of students and teachers has been diagnosed in their ideal Self to: increase authoritarianism; reduction of subordination; increased friendliness; a high level of anxiety has been established, which is an indicator of problems of perceptual pedagogical interaction of teacher-student.

Applied correlation and factor analysis allowed us to highlight the scales that have the greatest factor loads: "Anxiety and fears", "Submission", "Domination". These factors are the basic leverage for the future correction of the perceptivity of communication between teacher and student.

\section{REFERENCES}

1. Rachenko Y.P. (1999) Psychology of pedagogical creativity. Pyatigorsk: Publishing house of PSLU.

2. Klaryn M.V. (1994) Innovative models of teaching in foreign pedagogical searches. Moscow.

3. Zeer E.F. (2003) Psychology of vocational education. Moscow: Publishing House of the Moscow Psychological and Social Institute.

4. Klymov E.A. (1996) Psychology of professional selfdetermination. Rostov-on-Don: Phoenix.

5. Stepanov S.Yu., Polyshchuk O.A. \& Semenov Y.N. (1996) The development of reflective competence of management personnel. Moscow: Progress. 
6. Tkachuk S.I. (2010) Psychological and pedagogical bases of professional readiness of future teachers of labor training to formation of technological culture of students in general educational establishments. Scientific journal of MP Dragomanov National Pedagogical University. Series 13: Challenges for Employment and Training, vol. 6. pp. 200-207.

7. Halkyna N.V. (1990) The psychological mechanism for solving problems of assessment and self-esteem. Psychology of creativity. pp. 149-158.

8. Kulyutkyna Yu.N. \& Sukhobskoy H.S. (1990) Teacher Thinking: Personal mechanisms and conceptual apparatus. Moscow: Pedagogy.

9. Slastenyn V.A. (1976) The formation of the personality of the teacher of the Soviet school in the process of training. Moscow: Prosveshchenye.

10. Sokolova E.T. (1989) Self-awareness and self-esteem in case of personality anomalies. Moscow: Moscow State University.

11. Leont'ev A.N. (1975) Activity. Consciousness. Personality. Moscow: Polytyzdat.

12. Belukhyn D.A. (1994) Teacher: from love to hate ... Moscow.

\section{Information about the author:} Tatiana Scherban

Doctor of Psychology, Professor, Mukachevo State University 26, Uzhgorodska str., Mukachevo, Transcarpathian region, 89600, Ukraine ORCID ID: orcid.org/0000-0002-3702-8029

E-mail: schtata2015@gmail.com 


\section{SURVEY RESULTS ON MILITARY LEADER'S ABILITIES TO CREATE GENDER-SENSITIVE ENVIRONMENT}

\section{Olena Volobuieva}

\section{INTRODUCTION}

Whenever we speak about the gender equality we have to remember that it is considered to be an index of democratic society. Ukraine is in the period of the education sector reforming now and this period is characterized by promoting gender equality as one of the principle facts of successful country development in order to achieve the Sustainable Development Goals by $2030^{1}$.

In this connection we would like to stress that the leader's ability to create gender-sensitive environment for proper development of any organization is an indisputable factor, and much more in the process of the nature of organizational life and management of social group as organized system including the military ones. The knowledge of these aspects will give a leader the opportunity to regulate group processes and influence upon group dynamics for its effective organization and development on the grounds of social-psychological determinants of group influence upon individuals ${ }^{2}$ taking into consideration the.

Having analyzed the term 'gender training' we would like to point out that it is not only the activity aimed at forming and developing the certain skills and habits in order to carry out professional duties up to the level. But the leader has to be able to influence the individual's consciousness, to increase awareness, knowledge and practical skills and habits on gender issues by sharing information, experiences and techniques.

${ }^{1}$ The Sustainable Development Goals by 2030. Retrieved from https:// www.un.org/sustainabledevelopment/blog/tag/security-council/.Agenda2030.pdf.

${ }^{2}$ Volobuieva Olena (2018). Social group as organized system: psychological aspect. Mizhnarodny naukovyi zhurnal «Osvita i nauka»// red. kol. : T. D. Shcherban (hol. red.). Mukachevo-Chenstokhova: RVVMDU; ta Akademiia im. Yana Dluhosha. 2(25). [in Ukrainian] 
The leader's abilities to create gender-sensitive environment is absolutely important because it is considered to be the essential part of military leader's gender competence, especially, and we would like to stress this fact, in the process of carrying out the professional duties, namely in problem-solving. In this connection we want to emphasize that the democratic development of Ukrainian society urgently requires updating, making positive changes to the organizational culture of higher education military education, taking into account the requirements of the current legislation as for equality among the whole personnel $^{3}$.

The issue of improving the organizational culture of the gendersensitive environment in the context of a higher military educational establishment is extremely relevant nowadays. It is crucial for leaders at all levels to understand gender issues and to be able to analyze the relationships between male and female subordinates.

To find out the level of awareness and correct understanding of the gender component to the leadership management of the head of the military unit and awareness of the components of the organizational (institutional, corporate) culture of an officer in charge of the security and defense sector and to determine the further effective vectors to increase the level of formation of their gender competence the system of professional training of the State Border Guard Service of Ukraine (the ability to create favorable conditions in the unit taking in account 16 sign soft sensitivity to gender issues ${ }^{4}$ for the effective performance of professional task sand prevention of human rights violations of both women and men, a survey of the leaders fall the level soft he National Academy of the State Border Guard Service of Ukraine named after Bohdan Khmelnitskyi (NASBGSU) was conducted.

3 Beijing Declaration and Platform for Action and UN Resolution 1325, UN goals for the $3^{\text {rd }}$ Millennium that emphasized promoting gender equality and empowering women as priority goals. UN's Millenium Goals.

${ }^{4}$ Raj, A, Stuart, R. and Kelleher, D. What is gender at Work's Approach to Gender Equality and Institutional. Retrieved from https://www.genderatwork.org/sites/genderatwork.org/files/resources/Gender_at_Work s_Approach.pdf. 


\section{Military leader's abilities to create gender-sensitive environment as part of professional competence}

In the investigation we have taken into our consideration the fact that the type of the dominant organizational culture influences the way its members behave with each other, the relationships set between superior and subordinates, the atmosphere surrounding the organization ${ }^{5}$.

It goes without saying the organizational culture has to be based on diversity management and gender equality ${ }^{6}$.

The questionnaire for assessing the awareness of leveldetermination was worked out taking into our account the recommendations for conducting a survey of the heads of all security sector institutions, as suggested in the Megan Bestik Handbook on Gender Self-Assessment for the Police, Armed Forces and the Justice Sector?.

The experience of the author of the study within the State Border Guard Service of Ukraine, the results of observations, interviews with the heads of the structural units, monitoring the performance of their duties, the results of the analysis of the feedback concerning the graduates of NAS

BSU indicate that the leader's ability to create a gender-sensitive environment (the necessary level of organizational culture institutional, cooperative culture) has been essential for the successful implementation of the management activities of border guard officers.

5 Felicia Cornelia Macarie, CălinHințea,Cristina Mora.Gender and leadership.The impact on organizational culture of public institutions. Transylvanian Review of Administrative Sciences, No. 32 E/2011, pp. 146-156. Retrieved from https://www.researchgate.net/publication/292452492_Gender_and_Leadership_The_I mpact_of_Organizational_Culture_of_Public_Institutions.

${ }^{6}$ Stephanie Ernst (2013). Theorizing and Practizing Organizational Culture and Diversity. A Case Study //AnnoIII, Numero 6/Dicembre Retrieved from https://www.accaglobal.com/content/dam/acca/global/PDF-technical/humancapital/pol-tp-tbcfdm-diversity-management.pdf.

${ }^{7}$ Women, Peace and Security (2011). Geneva. 


\section{Empirical study}

The empirical study was carried out on the basis of the psychological knowledge of the abilities of heads of the structural units of the SBGSU taking into account the real conditions of the educational establishment.

One of the methods of our study is the conducting the survey of the structural units leaders regarding the understanding and assessment of their abilities to create gender sensitive environment; their significance and structure within the professional competence of the up-to-day leader of the security and defense sector.

The investigation of the leaders' opinions by asking them 21 questions was aimed at determining their awareness level as for the gender perspective in the military environment in the subordinate units as the principle factor which determines the effectiveness of group dynamics based on the importance of diversity management ${ }^{8}$. In the investigation we have taken into our consideration the fact that for creating positive atmosphere on the grounds of realizing the fact that only gender professionally competent leader (who has a number of the important qualities required for the successful management of the subordinate personnel in the military environment, including the significance of gender equality and women's empowerment for the security sector reform) is capable of managing the personnel and carrying out the moral and psychological support effectively within the framework of promoting equal opportunities for both female and male subordinates.

For conceptual clarity it is essential to mention that while analyzing the very nature of the leadership context we paid our attention to the fact that commitment, complexity, and credibility are typical of the leadership environment and the fact that the most important is learning which is called and it is important not just to learn but how to learn in an organizational context. The real leaders are able to concentrate on what matters most to the organization and to use the organization as a learning environment.

${ }^{8}$ Stephanie Ernst 2013. Theorizing and Practicing Organizational Culture and Diversity. A Case Study // Anno III, Numero 6/Dicembre. Retrieved from https://www.accaglobal.com/content/dam/acca/global/PDF-technical/humancapital/pol-tp-tbcfdm-diversity-management.pdf). 
Having analyzed the real state of the male attitude towards female leaders in the security sector we have come to the conclusion that it is essential to teach leaders gender. And in this connection we would like to emphasize that nowadays in spite of the fact that the personnel can use a lot of the training manuals on gender and security, attend the various gender-oriented trainings and seminars there is the need to form so-called proper gender ideology ${ }^{9}$.

On the first phase of our investigation in order to determine the level of the organizational skills of the leaders of the structural units of the NASBSU to create gender-sensitive environment two expert groups were formed.

The experts were selected according to the following basic requirements (their professional competence, interest, efficiency, objectivity). We have taken into account that: 1) the components of the expert's competence are the essential part of the professional competence that extends to the object of study and qualitative (expert) competence, which requires the expert's knowledge of expert solution methodology of the research problem (for example, the participation in the socio-psychological research); 2) an expert has to have the interest in the results of the expertise generally depends on expert knowledge and skill of the investigation subject, a positive attitude towards it and the expert's problem-solving ability using the non-traditional research methods (e.g. mathematical, sociological, expert), as well as analyticity, constructiveness and depth of one's thinking ${ }^{10}$.

It was taken into account that business efficiency is manifested in such properties of the expert as one's abilities to concentrate in teamwork especially on the gender differences conflict problem-solving, resist conformism, take into one's account only some information on the investigation subject and correct estimation (based on the results of the anonymous survey). We evaluated the experts' objectivity according to the results of their previous expert reviews. The requirements for the experts were the following: 1) a scientific degree;

${ }^{9}$ Volobuieva O. F. (2018). Volobuieva O. F. (2018). Leader and leadership of the security sector: gender aspect. Visnyk of the Taras Shevchenko National University of Kyiv Military-Special sciences, 1(38). [in Ukrainian].

${ }^{10}$ Cherepanov, V. (1989) Expert Assessment in Pedagogical research. Moscow : Pedagogics Publ. [in Russian] 
2) academic rank; 3) experience in a management position; 4) participation in the work of expert groups on related topics; 5) the attitude towards the up-to-date research methods including mathematical and expert ones. Taking into our consideration the recommendations of the expert assessment ${ }^{11}$. 6) we used the mutual recommendation methods, self-assessment, reasoning and questionnaire data to assess the competence of the experts. The mutual recommendations coefficient has been calculated by the following formula:

$$
K_{j}^{\beta 3}=\frac{x_{j}}{\sum_{j=1}^{m} x_{j}} \text { where }
$$

$x_{j}=\sum_{i=1}^{m} x_{i j}-$ the individual rating of the expert candidate; $x_{i j}-$ the number of choices; $m$ - the number of expert candidates.

According to the of mutual recommendations method, the group of 50 persons (including 17 females and 33 males ones) - the leaders of the structural units of the NASBSU with some leadership experience were selected among the candidates for the experts.

These were the very leaders who are responsible: 1) for organizing, supporting and controlling the service organization in subordinate units and moreover providing the moral and psychological support for the professional activity of subordinate personnel and also 2) for the organizational renewal for its development. In this connection for us was absolutely important the fact that data collection serves the important and useful functions in an organization development ${ }^{12}$.

We conducted the survey of the leaders of the structural units on the understanding and evaluating the importance of the leader's ability to create the gender-sensitive environment in their subordinate

${ }^{11}$ Cherepanov, V. (1989) Expert Assessment in Pedagogical research. Moscow: Pedagogics Publ. [In Russian]

${ }_{12}$ Lippitt, Gordon L. (1982). Organization renewal. A Holistic Approach to Organization Development, Second Edition. Printice - Hall, Inc., Englewood Cliffs, New Jersey, the USA. 
structural units as the essential part of their professional competence (i.e. the abilities to carry out their professional duties up-to-the level.

The obtained experts' evaluation results of the survey were used for the initial analysis. At the same time it was taken into our account the fact that with the help of survey it is possible to collect the quantitatively important material, which makes it possible to consider the received answers to be rather probable. The questionnaire (worked out by us), which has been used to reveal the experts views about the research area is shown below (table 1).

Table 1

\section{Questionnaire "Leader's Ability to Create Gender-Sensitive Environment as Part of Professional Competence"}

\section{Dear colleagues!}

Please answer the following questions:

\begin{tabular}{|c|c|}
\hline № & Questions \\
\hline 1 & 2 \\
\hline 1 & What is your scientific degree (if you have any)? \\
\hline 2 & What is your academic rank (if you have any)? \\
\hline 3 & $\begin{array}{l}\text { What is your experience of the leaders' position (please, mention the } \\
\text { number of the years)? }\end{array}$ \\
\hline 4 & $\begin{array}{l}\text { Could you explain the meanings of the terms: } \\
\text { 1) "gender" and 2) "sex", please. }\end{array}$ \\
\hline 5 & Please, reveal the meaning of the term "gender sensitive". \\
\hline 6 & $\begin{array}{l}\text { Please, explain the meaning of the term "responsibility of the } \\
\text { manager for the organizational (institutional) culture of the gender- } \\
\text { sensitive environment". }\end{array}$ \\
\hline 7 & $\begin{array}{l}\text { Do you think it is sufficient to have only the general abilities for } \\
\text { effective management of the unit? Is it obligatory for a leader to have } \\
\text { the specific abilities and knowledge in order to create gender- } \\
\text { sensitive environment? Why? }\end{array}$ \\
\hline 8 & $\begin{array}{l}\text { Are gender stereotypes and discrimination common in the unit you } \\
\text { manage? }\end{array}$ \\
\hline 9 & What does the term "leader's professional gender competency" mean? \\
\hline
\end{tabular}


End of Table 1

\begin{tabular}{|c|c|}
\hline 1 & 2 \\
\hline 10 & Is sexual harassment a common practice in the unit? (Yes / No)? \\
\hline 11 & $\begin{array}{l}\text { What personal characteristics are the indexes of the leader's ability to } \\
\text { create the gender-sensitive environment in the security and defense } \\
\text { sector? }\end{array}$ \\
\hline 12 & $\begin{array}{l}\text { Do you have any responsibility, as a leader, for gender equality in the } \\
\text { unit? }\end{array}$ \\
\hline 13 & $\begin{array}{l}\text { Are there any mutual respectful relationships between female and } \\
\text { male officers in your unit? }\end{array}$ \\
\hline 14 & $\begin{array}{l}\text { Are gender-based inequalities in the workplace (such as the } \\
\text { disrespectful computer screensavers, posters, jokes, no femininities } \\
\text { usage (if you have any) where appropriate) stopped or allowed in } \\
\text { your unit? In what way? Please, give some examples. }\end{array}$ \\
\hline 15 & $\begin{array}{l}\text { Do you think that the ability to create the gender-sensitive } \\
\text { environment is part of the professional competence of the effective } \\
\text { leader? If so, is it innate or can it be during the training and further } \\
\text { service of officers? }\end{array}$ \\
\hline 16 & $\begin{array}{l}\text { Could you describe the effective leader who is able to create the } \\
\text { proper gender-sensitive environment, please? }\end{array}$ \\
\hline 17 & $\begin{array}{l}\text { Please, describe an officer who can never be a successful leader } \\
\text { because of his/her gender stereotypes. }\end{array}$ \\
\hline 18 & $\begin{array}{l}\text { Is there understanding between the male and female personnel in } \\
\text { your unit? }\end{array}$ \\
\hline 19 & $\begin{array}{l}\text { The gender policy is being realized and gender is being integrated } \\
\text { into the educational process effectively at the National Academy of } \\
\text { the State Border Guard Service of Ukraine named after Bohdan } \\
\text { Khmelnitsky. Do all your subordinates know about these facts? } \\
\text { (Yes / No). }\end{array}$ \\
\hline 20 & $\begin{array}{l}\text { What are the differences between the views of women and men on } \\
\text { gender issues in the unit? }\end{array}$ \\
\hline 21 & $\begin{array}{l}\text { What information do the new personnel get about the commitments } \\
\text { to providing gender equality and human rights at the NASBGSU? }\end{array}$ \\
\hline
\end{tabular}

Thank you very much for your answers!

The characteristics of the personnel who participated in the survey are shown below in table 2 . 
Table 2

Characteristics of Personnel Participated in Survey

\begin{tabular}{|l|c|c|c|c|c|c|}
\hline \multicolumn{1}{|c|}{$\begin{array}{c}\text { Characteristics } \\
\text { of the personnel }\end{array}$} & \multicolumn{2}{|c|}{ Female } & \multicolumn{2}{c|}{ Male } & \multicolumn{2}{c|}{ Total } \\
\cline { 2 - 7 } & number & $\%$ & number & \% & number & $\%$ \\
\hline $\begin{array}{l}\text { Personnel with the } \\
\text { rank of Professor }\end{array}$ & 4 & $23,53 \%$ & 3 & $9,09 \%$ & 7 & $14 \%$ \\
\hline $\begin{array}{l}\text { Personnel with the } \\
\text { rank of Assistant } \\
\text { Professor }\end{array}$ & 10 & $58,82 \%$ & 6 & $18,18 \%$ & 16 & $32 \%$ \\
\hline $\begin{array}{l}\text { Personnel with no } \\
\text { academic rank }\end{array}$ & 3 & $17,65 \%$ & 24 & $72,73 \%$ & 27 & $54 \%$ \\
\hline $\begin{array}{l}\text { Personnel with Doctor } \\
\text { of Sciences Degree }\end{array}$ & 5 & $29,41 \%$ & 4 & $12,12 \%$ & 9 & $18 \%$ \\
\hline $\begin{array}{l}\text { Personnel with } \\
\text { a PhD degree }\end{array}$ & 11 & $64,71 \%$ & 11 & $33,33 \%$ & 22 & $44 \%$ \\
\hline $\begin{array}{l}\text { Personnel with no } \\
\text { scientific degree }\end{array}$ & 1 & $5,88 \%$ & 18 & $54,55 \%$ & 19 & $38 \%$ \\
\hline $\begin{array}{l}\text { Have more than } \\
\text { 20 years of senior } \\
\text { management } \\
\text { experience }\end{array}$ & 2 & $11,76 \%$ & 4 & $12,12 \%$ & 6 & $12 \%$ \\
\hline $\begin{array}{l}16-20 \text { year experience } \\
\text { in management } \\
\text { positions }\end{array}$ & 3 & $17,65 \%$ & 3 & $9,09 \%$ & 6 & $12 \%$ \\
\hline $\begin{array}{l}11-15 \text { year experience } \\
\text { in management } \\
\text { positions }\end{array}$ & 6 & $35,29 \%$ & 11 & $33,33 \%$ & 17 & $34 \%$ \\
\hline $\begin{array}{l}6-10 \text { year experience } \\
\text { in management } \\
\text { positions }\end{array}$ & 5 & $29,41 \%$ & 10 & $30,30 \%$ & 15 & $30 \%$ \\
\hline $\begin{array}{l}\text { Leadership experience } \\
\text { is less than 5 years }\end{array}$ & 1 & $5,88 \%$ & 5 & $15,15 \%$ & 6 & $12 \%$ \\
\hline
\end{tabular}

\section{Survey analysis results}

The analysis results of the survey testify about the fact that all the respondents do not find any gender stereotypes (the answers to the Question 8) and sexual harassment (the answers to the Question 10) to be a common practice in their units. 
The respondents' answers to the questions 13, 15, 18 and 19 are the positive ones as for:

- the necessity of the respectful relationships between the female and male officers in the units (question 13);

- the ability to create the gender-sensitive environment (which is considered to be part of the effective leader's professional competence and which is not innate and that is to be formed in the process of special gender-aimed training (question15);

- understanding between female and male personnel in the unit (question 18);

Concerning the realization of the gender policy at the NASBGSU and gender mainstreaming into the educational process (question 19) the questioned leaders have also given the positive answer.

As for:

- the leader's responsibility for gender equality in the unit (question12)49 respondents answered briefly:" Yes." and one person has given the following reply "Yes, I as the leader of the military unit adhere to the principle of equality. It is my duty";

- the gender-based inequalities in the workplace(question 14), the answers with the numbers of respondents are the following:

- "women should not be in the army"- 2 answers of the male leaders- $4 \%$;

- "the cases of gender inequality happened at the workplace" 48 answers (16 answers of female and 28 of male leaders);

- revealing the meaning of the terms 'gender' and 'sex' (question 4), the majority of the respondents (total number - 44, including 16 female and 28 male officers have given the same answer, namely they find: "gender" to be a social concept which defines the traits and behaviors that are typical of women and men in a particular society and 2) sex to be a biological concept, the state of being male or female.

We would like to point out that speaking about the respondents answers to question 5 which deals with the leaders' understanding of the term "gender-sensitive environment" the opinions of the leaders are the following:

- 11 respondents $(22 \%)$ have not defined the term correctly;

- 39 leaders find the term to be:

1) the environment where the gender-based conflicts can occur 16 people $(32 \%)$; 
2) the environment where women are the equal partners with men in any field of professional activity -13 people $(26 \%)$;

3 ) the environment where the colleagues understand, respect and support each other and help everyone to realize their abilities and make the career -6 people (12\%);

4) the environment where there are no gender stereotypes, and which is sensitive to the relevant changes and promotes effective activity -4 people $(8 \%)$.

As for the explanation of the meaning of the term "responsibility of the manager for the organizational (institutional, corporative) culture of the gender-sensitive environment" such answers have been given to the question as:

- cultivating by the leader of the unit the rights of both male and female representatives at their workplace -12 persons $(24 \%)$;

- the leader of the unit regularly organizes round table discussions on gender agenda within of the gender program which is aimed at supporting gender balance in the unit - 12 people (24\%);

- the head of the unit is responsible for promoting gender policy -9 people (18\%);

- obligatory maintaining gender balance -8 people $(16 \%)$;

leader's personal responsibility for the proper monitoring and maintaining the gender-sensitive environment -9 persons $(18 \%)$.

The respondents' answers to question 7 which touches upon the aspect of the importance of the general and specific abilities for effective management, particularly for creating the gender-sensitive environment, are the following:

- 29 people $(58 \%)$ have found the specific abilities to be obligatory for proper management and creating the positive genderbased atmosphere;

- 12 people (24\%) have considered the specific ability to be essential because they are more related to behaviors in the unit (as a group). (The specific abilities include not only those which may be reflected in the general ability, but also special skills and knowledge ${ }^{13}$;

${ }^{13}$ Shaw E. Marvin. (1976). Group Dynamics. The Psychology of Small Group. The USA : McGraw-Hill. 
- 9 people (18\%) have answered that it is not enough to possess only the general abilities, to their opinion the very specific abilities and essential knowledge are an integral part of the effective leader proficiency.

As for the meaning of the term "leader's professional gender competence" the answers to the question 9are the following:

- everything related to the professional activity of a manager 21 persons $(42 \%)$;

- combination of professionalism with gender competence 14 persons $(28 \%)$;

- effective competence of the manager in the system of intergender relations -4 persons $(8 \%)$;

- ability to prevent gender discrimination in the unit -3 persons $(6 \%)$;

- tactful and correct attitude to gender differences -3 persons $(6 \%)$

- acquired knowledge and abilities to provide the gendersensitive environment -3 persons $(6 \%)$;

- knowledge of the traits of female and male behavior characteristic -3 persons $(6 \%)$.

While answering question 11 the following typical personal characteristics (as the index of the leader's ability to create the gendersensitive environment in the security and defense sector) have been mentioned:

1) awareness of understanding the importance the gender equality issues, tolerance, flexibility, respect for subordinates regardless of their gender;

2) the ability to eliminate the gender hierarchy between female and male representatives;

3) diagnostic ability, flexibility, correctness, peaceful attitude;

4) the ability to notice and adequately assess situations of gender inequality, avoid gender discriminatory practices;

5) the team-work ability, empathy, professional competence;

6) management responsibility and the ability to see personality in subordinate personnel.

As for question 16 according to the respondents' opinions the principle traits of a "commander who is able to create the gendersensitive environment" are the following: 
- equal attitude towards female and male representatives 7 people $(14 \%)$

- a professionally competent leader who is capable of creating a gender-sensitive environment on the basis of politeness and respect 43 people (86\%).While answering question 17 (question on the description of the officer who can never be a successful leader because of gender stereotypes the majority of respondents (42 leaders $84 \%$ )have expressed their opinions in such a way:

They find the direct connection of the existence of gender stereotypes with the leader's management strategy for effective group dynamics which depends on the leader1s gender professional competence.

8 respondents (16\%) expressed such opinions as:

- a hating officer violating the human rights of the representatives;

- an officer who cannot prevent and resolve gender issues and conflicts;

- a supporter of discrimination, supports gender inequality, seeks authority, distrust to women in their tasks performance;

- cheeky, sloppy, irreconcilable to the opposite gender;

- not ready for self-improvement;

- an officer who does not respect the opinion of a person of the other gender;

- a gender biased officer believes that gender stereotypes are the traditional ones and does not want to understand the importance of the gender tolerance and leader's responsibility to create the gendersensitive environment.

What information do the new personnel get about the commitments to providing gender quality and human rights at the NASBGSU?

As for question 21 - the question on informing the new personnel about gender equality of the NASBGSU the answers have testified that they are informed about:

- the Regulations on the Subdivision of the National Academy of the State Border Guard Service of Ukraine , particularly, unit III "On Gender Policy" - 3 persons (6\%);

- special instruction on prevention of gender discrimination 2 persons $(4 \%)$; 
$(6 \%)$;

- on providing the gender sensitive environment - 3 persons

- some information on gender integration into the educational process -4 persons $(8 \%)$;

- on the implementation of gender equality in security and defense sector -38 persons $(76 \%)$.

\section{CONCLUSION}

1. Having analyzed the results of the survey we have come to the following conclusion:

2. Not all the interviewed officers have given the correct definition of the terms 'gender-sensitive environment' and 'leader's professional gender competence'. This fact testifies about the fact that at the level of their awareness they do not understand, as any up-todate leader has to, the very nature of the proper created environment for the effective professional activity.

3. There is some concern at the level of male executives' awareness of the proper perception of gender roles and gender as a phenomenon in the military environment, where gender stereotypes are traced, which negatively affects the moral and psychological climate in the units and as a consequence the effectiveness of the professional performance.

4. Leaders at all levels need to be educated in gender specifics in order to form the appropriate level of their gender competence the proper level of which will guarantee the essential level of creating the gender-sensitive environment in the units.

5. In order to form the necessary level of the leaders' gender professional competence itself vital importance to involve leaders into the special gender training.

6. The effective personnel policy and successful management play an important role in making changes to the organizational culture of the unit in the conditions of the higher educational establishment.

In this context we would like to point out that as for the essence of the concept of the organizational culture (institutional culture, corporative culture) authors A. Raj, R. Stuart, and D. Kelleher, give the following definition of the term "institutional culture" as a set of 
values, history, and ways of doing things that shape the unspecified "rules of the game" in an institution".

7. The very organizational (institutional, corporative) culture can be a powerful ally in ensuring gender equality in the most valuable part of an institution's activity, or it can block progress on gender issues making it difficult for women to be real personality and develop oneself in harmony with other female colleagues.

8. While investigating the results of the survey we have noticed the tendency in the respondents' answers that it is important for them to increase the level of their awareness as for the importance of taking into their accounts the fact that gender perspective is absolutely important for the development of the unit as a group and rise in effectiveness of the group organization and management of female and male group members' activities is aimed to improving human resources (HR) management. Within any group there is a number of recognized roles that are generally accepted as relevant for intragroup interaction and activity. We are interested not only in the regularities of collaborative female and male individuals in the framework of group processes, but also in the personality of separate group member and the peculiarities of the very organization of his/her individual activity within the framework of social group as organized system ${ }^{15}$ in the military environment.

9. In the survey of the leaders it has been found that there do some significant not understand the peculiarities of the very organizational culture as the process of the very change process of the whole unit as the organization development which attempts to integrate female and male individual needs for growth and development with organizational goals and objectives in order to make a more effective organization ${ }^{16}$.

${ }^{14}$ Raj, A, Stuart, R. and Kelleher, D. What is gender at Work's Approach to Gender Equality and Institutional. Retrieved from http://www.genderatwork.org/ sites/genderatwork.org/files/resources/Gender_at_Works_Approach.pdf.

${ }^{15}$ Volobuieva Olena. (2018). Social group as organized system: psychological aspect. Mukachevo-Chenstokhova: RVVMDU; ta Akademiia im. Yana Dluhosha. 2(25). [in Ukrainian]

${ }^{16}$ Lippitt, Gordon L. (1982). Organization renewal. A Holistic Approach to Organization Development, Second Edition. Printice - Hall, Inc., Englewood Cliffs, New Jersey, the USA. 
That is why it is essential to pay attention to the role of consciousness in the system of professional training the whole personnel.

10. Moreover it is essential to study the problems of female and male individuals interaction in the system "conscious leader of the unit - conscious subordinate".

11. Taking into consideration the fact that conscious is the highest level of activity relation on the grounds of the particular values of the concrete military unit (as a group) member it is absolutely important to provide conscious attitude of the whole personnel towards the very gender process which determines his/her effective cognitive activity, maximum creative activity and independence. That is why the process of gender training is to be organized in such a way in order to promote conscious active interaction between both the teacher and the subject of the training process.

12. In order to create the proper gender sensitive environment in the unit the leader has to be good at group dynamics and specific peculiarities of gaining some gender knowledge by the whole personnel of the group on the proper socio-psychological provision basis.

13. For effective forming of the essential level of gender professional competence it is necessary to use problem-solving situations on the basis of socio-psychological determinants of group influence. The usage of such situations gives the opportunity to form some psychological operations and their complexes through the interaction of various kinds of gender based professional activities on the basis of taking into one's consideration the gender differences within the group structure.

14. Taking into account the fact that leader is the person who is in the focus of group behavior and leadership is the process or act of influencing. A unit is assigned formal power to hire, discharge, reward, and penalize the individuals in order to mold their behavior in the pattern of the organization's objectives on the grounds of the organizational culture in the military environment.

15. While using the particular methods of gender problem solving it is of vital importance for the leader to remember about the "familyfriendly" policy in the conditions of the higher military educational establishment. The leader of the unit has to be good at understanding 
the organizational culture of gender-sensitive environment, its mission and basic aspects of relationship system, which should be taught purposefully, systematically and comprehensively. In this context, the recommendations of Women's Information and Advisory Center deserve attention ${ }^{17}$.

16. In the context of investigating the leader's ability to form the favourable gender-sensitive environment for the whole personnel, itis extremely important for us roundest and the sense of the term "leader's behaviour culture" is a set of formed, socially significant personality traits, actions in based on the norms of morality, ethics, aesthetics and culture $^{18}$.

For a leader of any rank, itis extremely important to have a high level of behaviour culture, the proper level of which ensures the following moral bases as the essentials of the leader's gender professional competence as: 1) fulfilment of their duties sand moral requirements, demanding of one self and others, active and proactive actions, respect for rights and freedoms of both female and male personnel; assistance and support of subordinates, including in realization of personal capacities and abilities on gender perspectives basis; 2) responsibility - a duty to help or take care of the personnel because of the position ${ }^{19}$; respect for human dignity; respect for another person as a unique personality, etc.

17. Effective personnel policy and successful management play an important role in making changes to the organizational culture of the unit in the conditions of the higher military educational establishment. It is urgent for a manager of an educational institution to have a proper understanding of organizational culture, its mission and the basic aspects of its system of relationship. In this connection we would like to point out that Angela Workman-Stark, PHD, associated

17 Suslova, O. (2019). Systemic Reforms: The Principle of Equal Rights and Opportunities for Women and Men and Anti-Discrimination Approach. Kyiv. [in Ukrainian]

18 Education. Encyclopedia Academy of Pedagogical Science of Ukraine / ed. V. Kremen' (2008) Yurinkom Inter. Kyiv. [In Ukrainian]

19 Hornby A. S. (2005). Oxford Advanced Learner's Dictionary of Current English, Oxford University Press, the Seventh Edition. 
professor and program director of Faculty of Business at Athabasca University, Canada, having a 24-year career in the federal law enforcement in the academic article "Creating Inclusive Teams. Six Essential Steps for leaders" attracts our attention to the fact that it is essential for a leader to find the balance approach, which gives the opportunity to integrate diverse female and male individuals into the workplace while at the same time respecting and harnessing individual differences ${ }^{20}$.

18. The comprehensive integration of gender equality dimensions into the education sector reforming processes, which is taking place in the defense, and security sector of Ukraine is critical to meet the standards of representative and rights-respecting needs of women. That is why nowadays it is essential to change the way every leader is thinking about the gender phenomenon (which is not fully understood in the Ukrainian society).

19. The results of the investigation have testified the necessity of the rise in the level of the leaders' gender organizational abilities at all the levels of professionalization.

The size of the article does not give us the opportunity to reveal all the results of our investigation. The further direction sin the process of investigation of the problem of the leaders' gender organizational abilities are: 1) studying the role of the leader's consciousness in the process of creating inclusive teams; 2) working out the Program of the forming gender competence of the organizational abilities of the border guard officers, students and cadets of the NASBGS of Ukraine.

\section{SUMMARY}

The article deals with revealing the results of the investigation of leader's ability to create gender-sensitive environment. We consider gender competence to be the essential part of the leader's professional competence, i.e. the ability to perform the professional duties up to the level. We have worked out the questionnaire on the leader's ability to create the gender-sensitive environment within

${ }^{20}$ Workman-Stark Angela. Creating Inclusive Teams. Six Essential Steps for leaders. BEP Business Expert Press. Retrieved from https:www.businessexpertpress.com. 
the framework of organizational culture in the conditions of the higher military educational establishment. The results of the investigation testify that it is of vital importance to teach leaders gender in order to develop their abilities to create gender-sensitive environment in the units effectively. The gender knowledge will give a leader the opportunity to regulate group processes and influence upon group dynamics for its effective organization and development.

The results of the investigation have testified:

1) the necessity of the rise in the level of the leaders' gender organizational abilities at all the levels of professionalization;

2) the importance of providing the conscious attitude of leader towards gender training as the essential part of the professional development in order to have the proper level of professional gender competence.

3) the results of the investigation will give us the opportunity to study the peculiarities of the leader's consciousness role in the process of professional training.

The size of the article does not give us the opportunity to reveal all the results of our investigation. The further directions of the studying the problem of the leaders 'gender organizational abilities are:

1) studying the role of the leader's consciousness in the process of creating inclusive teams;

2) working out the Program of forming gender competence of the organizational abilities of the border guard officers, students and cadets of the National Academy of the State Border Guard Service of Ukraine named after Bohdan Khmelnitskyi.

\section{REFERENCES}

1. Beijing Declaration and Platform for Action. https://www.un.org/en/events/pastevents/pdfs/Beijing_Declaration_and _Platform_for_Action.pdf.

2. Cherepanov, V. (1989). Expert Assessment in Pedagogical research. Moscow: Pedagogics Publ. [in Russian].

3. Ernst Stephanie (2013). Theorizing and Practizing Organizational Culture and Diversity. A Case Study // Anno III, Numero 6 / Dicembre. Retrieved from https://www.accaglobal.com/ 
content/dam/acca/global/PDF-technical/human-capital/pol-tp-tbcfdmdiversity-management.pdf.

4. Gender and Security. (2012). Training Manual. UN Women, DCAF.

5. Hornby A. S. (2005). Oxford Advanced Learner's Dictionary of Current English, Oxford University Press, the Seventh Edition.

6. Macarie Felicia Cornelia, Hinţea Călin, Mora Cristina. Gender and leadership the impact on organizational culture of public institutions. Transylvanian Review of Administrative Sciences, No. 32 E/2011, pp. 146-156. p. 147) Retrieved from https://www.research gate.net/publication/292452492_Gender_and_Leadership_The_ Impact_of_Organizational_Culture_of_Public_Institutions.

7. Women, Peace and Security (2011). Geneva.

8. Raj, A, Stuart, R. and Kelleher, D. What is gender at Work's Approach to Gender Equality and Institutional. Retrieved from http://www.genderatwork.org/sites/genderatwork.org/files/resources/ Gender_at_Works_Approach.pdf.

9. Sustainable Development Goals by 2030. Retrieved from https://www.un.org/sustainabledevelopment/blog/tag/security-council. Agenda 2030.pdf.

10. Volobuieva O. F. (2018). Leader and leadership of the security sector: gender aspect. Visnyk of the Taras Shevchenko National University of Kyiv Military-Special sciences, 1(38). [in Ukrainian].

11. Volobuieva Olena. (2018). Social group as organized system: psychological aspect. Mizhnarodnyi naukovyi zhurnal "Osvita i nauka": RVVMDU; ta Akademiiaim. Yana Dluhosha. 2(25). [in Ukrainian]

12. Lippitt, Gordon L. (1982). Organization renewal. A Holistic Approach to Organization Development, Second Edition. Printice Hall, Inc., Englewood Cliffs, New Jersey, the USA.

13. Shaw Marvin E. (1976). Group Dynamics. The Psychology of Small Group Behavior, McGraw-Hill Book Company, the USA.

14. The significance of gender equality and women's empowerment for the security sector reform. OECD DAC Handbook on security system reform. Section 15: Integrating Gender Awareness and Equality, OECD, 2009 Edition. http://www.oecd-ilibrary.org. 
15. Systemic Reforms (2019).The Principle of Equal Rights and Opportunities for Women and Men and Anti-Discrimination Approach. Kyiv. [In Ukrainian].

16. Education. Encyclopedia Academy of Pedagogical Science of Ukraine / ed. V. Kremen (2008). Yurinkom Inter. Kyiv. [In Ukrainian].

\section{Information about the author:}

Olena Volobuieva

Doctor of Sciences in Psychology, Professor, Academic Research Deputy Rector,

National Academy of the State Border Guard Service of Ukraine named after Bohdan Khmelnytskyi 46, Shevchenko str., Khmelnytskyi, 29003, Ukraine ORCID ID: orcid.org/0000-0003-4010-6398 E-mail: helen_volobueva@ukr.net 
NOTES 
Publishing house "Liha-Pres"

9 Kastelivka str., Lviv, 79012, Ukraine 44 Lubicka str., Torun, 87-100, Poland

Printed by the publishing house "Liha-Pres"

Passed for printing: November 25, 2019. A run of 150 copies. 